\title{
Molecular genetic analysis of Will Die Slowly 2 (WDS2) gene in Arabidopsis thaliana
}

\author{
By \\ Adel Al-Shammari
}

A thesis Submitted to the Faculty of Graduate Studies and Research of Carleton University, in partial fulfillment of the requirements for the degree of a Master of Science in Biology.

Department of Biology

Carleton University

Ottawa, ON, Canada

2009

(C) Copyright

2009, Adel Al-Shammari 
Library and Archives

Canada

Published Heritage

Branch

395 Wellington Street

Ottawa ON K1A ON4

Canada
Bibliothèque et

Archives Canada

Direction du

Patrimoine de l'édition

395, rue Wellington Ottawa ON K1A ON4

Canada

Your file Votre référence

ISBN: 978-0-494-60195-2

Our file Notre refférence

ISBN: 978-0-494-60195-2

NOTICE:

AVIS:

The author has granted a nonexclusive license allowing Library and Archives Canada to reproduce, publish, archive, preserve, conserve, communicate to the public by telecommunication or on the Internet, loan, distribute and sell theses worldwide, for commercial or noncommercial purposes, in microform, paper, electronic and/or any other formats.

The author retains copyright ownership and moral rights in this thesis. Neither the thesis nor substantial extracts from it may be printed or otherwise reproduced without the author's permission.

L'auteur a accordé une licence non exclusive permettant à la Bibliothèque et Archives Canada de reproduire, publier, archiver, sauvegarder, conserver, transmettre au public par télécommunication ou par l'Internet, prêter, distribuer et vendre des thèses partout dans le monde, à des fins commerciales ou autres, sur support microforme, papier, électronique et/ou autres formats.

L'auteur conserve la propriété du droit d'auteur et des droits moraux qui protège cette thèse. $\mathrm{Ni}$ la thèse ni des extraits substantiels de celle-ci ne doivent être imprimés ou autrement reproduits sans son autorisation.

In compliance with the Canadian Privacy Act some supporting forms may have been removed from this thesis.

While these forms may be included in the document page count, their removal does not represent any loss of content from the thesis.
Conformément à la loi canadienne sur la protection de la vie privée, quelques formulaires secondaires ont été enlevés de cette thèse.

Bien que ces formulaires aient inclus dans la pagination, il n'y aura aucun contenu manquant. 


\section{ACKNOWLEDGEMENTS}

I would like to thank my co-supervisors, Dr. Tim Xing and Dr. Owen Rowland, for giving me the opportunity to complete my Master degree at Carleton University and for their inputs. I am also grateful for the financial support provided by UZK\& Partners Investments and to Carleton University for providing research facilities and financial support. I would also like to thank Dr. Doug Johnson, and Dr. Shelley Hepworth for their helpful comments and suggestions on this project. Also, l'd like to thank Denise Chabot from Agriculture and Agri-Food Canada and lan Pulsifer from Carleton University for their help with the confocal microscope. Final thanks must be given to Alhattab, my family, lab members and friends for their support. 


\section{TABLE OF CONTENTS}

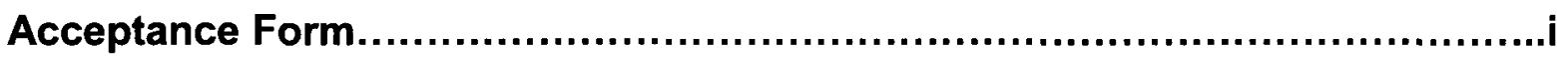

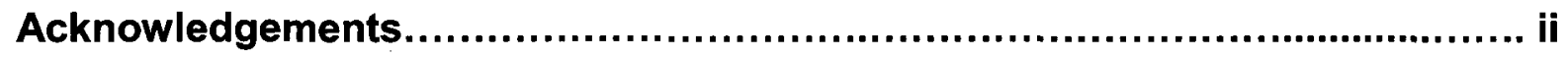

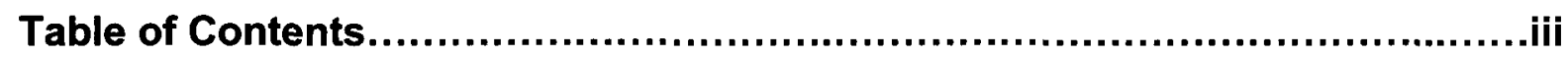

List of Abbreviations.....................................................................

List of Tables.............................................................................

List of Figures..............................................................................

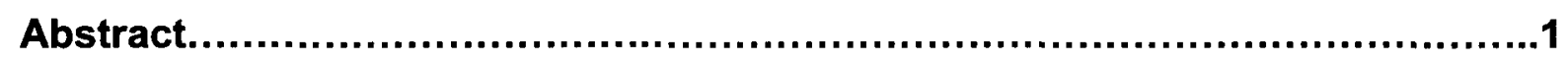

\section{Chapter1:}

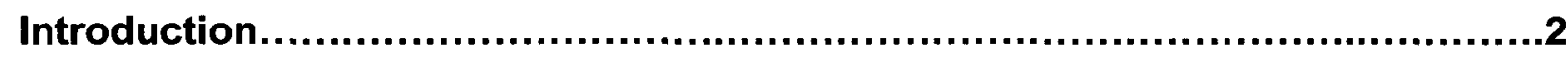

1.1 PCD in different categories of plant cells ...........................................

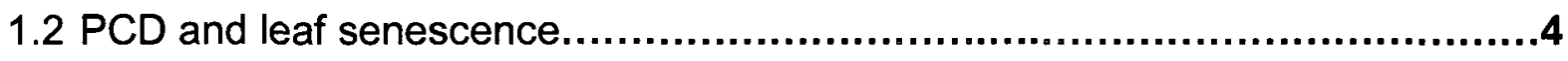

1.3 PCD and plant disease resistance................................................

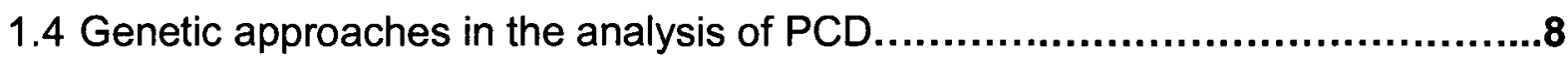

1.5 Salicylic acid has a role in regulating gene expression during leaf senescence..........................................................................

1.6 FB1-induced cell death in Arabidopsis requires SA dependent signalling pathway.............................................................................11

1.7 Mannitol accumulation in response to abiotic and biotic stresses..................12

1.8 Plant MAPK cascades play a role in leaf senescence............................13

1.9 Will Die Slowly (WDS) family members............................................15

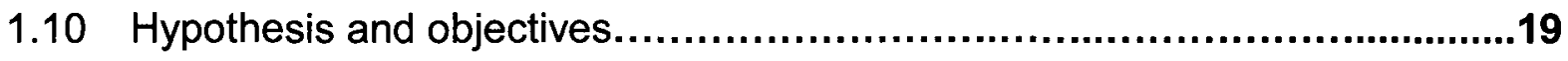




\section{Chapter 2:}

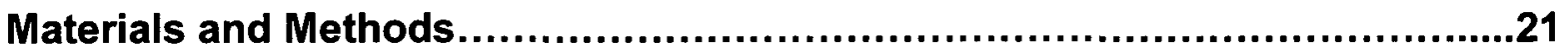

2.1 Plant materials and growth conditions.........................................21

2.2 Genotyping loss-of-function T-DNA lines.........................................22

2.3 Confirmation of loss-of-function using reverse transcriptase PCR (RT-PCR) to

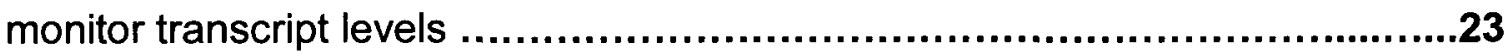

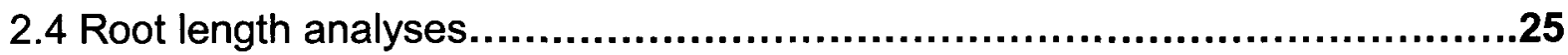

2.5 Treatment with Salicylic acid (SA) and chlorophyll content analysis..................26

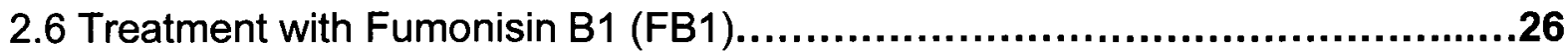

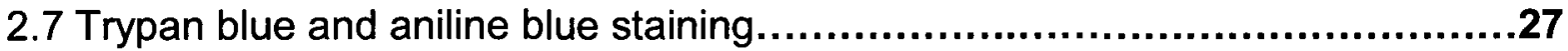

2.8 DNA construct for fusion of WDS2 with green fluorescent protein, transformation in to Agrobacterium tumefaciens, and transient delivery into plant

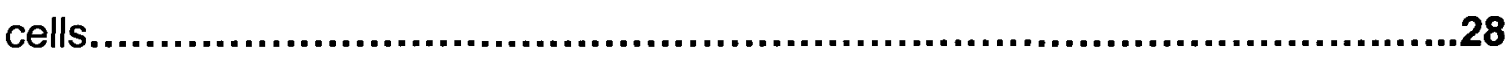

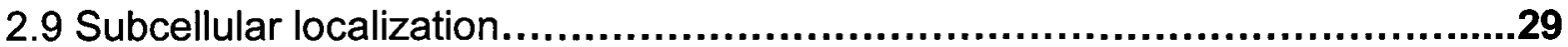

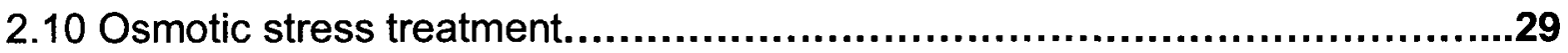

\section{Chapter 3:}

Results

3.1 Isolation and molecular characterization WDS2.

3.2 Mutant phenotypes of wds1, wds2 and wds1 wds2

3.3 Response of WDS2 to hyperosmotic stress........................................46

3.4 Response of WDS1 and WDS2 to abiotic stress treatment..........................50

3.5 Up-regulation of WDS1 and WDS2 transcripts by SA....................................53 
3.6 Leaf senescence induced by senescence-accelerating hormones such as salicylic acid (SA) is accelerated in wds2. 56

3.7 Fumonisin B1 induces cell death in wds2 and wds1 wds2......................61

3.8 Subcellular localization of WDS2. .71

\section{Chapter 4:}

Discussion.

4.1 Structure and function of WDS2 .78

4.2 WDS2 functions in the regulation of leaf senescence and plant development. .79

4.3 Regulation of WDS2 processing by osmotic stress. .82

4.4 Up-regulations of WDS by salicylic acid. .83

4.5 Interaction of senescence and defense responses .85

Conclusion. 87

Future direction. .88

Appendix A: Diagram of WDS2 Construct Map.

Appendix B: Salicylic acid biosynthetic pathways in plants .93

References. .94 


\section{LIST OF ABBREVIATIONS}

Et : Ethylene

FB1: Fumonisin B1

HR: Hypersensitive Response

JA: Jasmonic Acid

LD: Long Day

PR: Pathogenesis-related

PCD: Programmed Cell Death

ROS: Reactive Oxygen Species

SA: Salicylic Acid

SEFs: Senescence-enhanced factors

SAGs: Senescence Associated Genes

SAR: Systemic Acquired Resistance

SD: Short Day

TEs: Tracheary Elements

TUNEL: Terminal Deoxynucleotidyl transferase d-uridine triphosphate Nick end Labeling

WD40-RPs: WD40 repeat proteins

WDS: Will Die Slowly 


\section{LIST OF TABLES}

\begin{tabular}{|c|l|c|}
\hline Table & \multicolumn{1}{|c|}{ Title } & Page \\
\hline 3.1 & $\begin{array}{l}\text { Members of the Arabidopsis WDS gene family and SALK } \\
\text { T-DNA insertion lines }\end{array}$ & 33 \\
\hline 3.2 & $\begin{array}{l}\text { Flowering time, leaf numbers, silique size }(\mathrm{mm}) \text { and root } \\
\text { length }(\mathrm{cm}) \text { of } w d s 1 \text { and } w d s 2 \text { and } w d s 1 \text { wds2 mutants. }\end{array}$ & 46 \\
\hline
\end{tabular}




\section{LIST OF FIGURES}

\begin{tabular}{|c|c|c|}
\hline Figure & Title & Page \\
\hline 1.1 & $\begin{array}{l}\text { Phylogenetic tree (a) and domain structure (b) of WDS } \\
\text { family members }\end{array}$ & 18 \\
\hline 3.1 & $\begin{array}{l}\text { Schematic map of the genomic regions corresponding to } \\
\text { WDS2 gene with mutation sites indicated }\end{array}$ & 34 \\
\hline 3.2 & $\begin{array}{l}\text { PCR amplification for identification of homozygous mutant } \\
\text { lines of } w d s 1, w d s 2 \text { and } w d s 1 \text { wds } 2 \text { mutants }\end{array}$ & 36 \\
\hline 3.3 & $\begin{array}{l}\text { Semi-quantitative RT-PCR analysis of mRNA accumulation } \\
\text { of WDS2 in Col-0 wild-type and } w d s 2 \text { mutant }\end{array}$ & 38 \\
\hline 3.4 & $\begin{array}{l}\text { Phenotypic analysis of } w d s 1, w d s 2 \text { and } w d s 1 \text { wds } 2 \text { mutants } \\
\text { in long-day and short-day condition }\end{array}$ & 42 \\
\hline 3.5 & $\begin{array}{l}\text { The effect of hyperosmotic stress on wild type, wds1, wds2, } \\
\text { and } w d s 1 \text { wds } 2 \text { in tissue culture }\end{array}$ & 48 \\
\hline 3.6 & $\begin{array}{l}\text { RT-PCR analysis of WDS2 expression in wild-type seedlings } \\
\text { with } 0.6 \mathrm{mM} \text { D-mannitol treatment. }\end{array}$ & 51 \\
\hline 3.7 & $\begin{array}{l}\text { RT-PCR analysis of WDS1 and WDS2 expression in wild- } \\
\text { type Arabidopsis leaves with } 0.5 \mathrm{mM} \mathrm{SA} \text { treatment. }\end{array}$ & 54 \\
\hline 3.8 & $\begin{array}{l}\text { The change of chlorophyll content in response to SA } \\
\text { treatment }\end{array}$ & 57 \\
\hline 3.9 & $\begin{array}{l}\text { Microscopic image of whole-mounted Col-0, wds1, wds2, } \\
\text { wds1 wds2 leaves }\end{array}$ & 63 \\
\hline 3.10 & $\begin{array}{l}\text { Microscopic image of callose deposition in Col-0, wds1, } \\
w d s 2, w d s 1 \text { wds2 leaves after } 5 \mu \mathrm{M} \text { FB1 treatment. }\end{array}$ & 69 \\
\hline 3.11 & $\begin{array}{l}\text { Nuclear localization of GFP-WDS2 in DAPI blue-treated } \\
\text { transgenic tobacco plants }\end{array}$ & 72 \\
\hline 4.1 & $\begin{array}{l}\text { A proposed model showing signalling pathways leading to } \\
\text { WDS gene expression during PCD process. }\end{array}$ & 90 \\
\hline
\end{tabular}




\begin{abstract}
Programmed cell death is a complex process that involves the selective elimination of unwanted cells and is controlled by multiple developmental and environmental signals. Senescence, as a visible form of cell death, is an active process that involves the increased expression of multiple genes and represents a highly regulated developmental stage. In this project, I characterized mutants of the Will Die Slowly (WDS) 1 and 2 genes. The mutants wds2 and wds1 wds2 displayed accelerated leaf senescence, increased chlorophyll leaching and increased sensitivity to osmotic stress, indicating that expression of WDS1 and WDS2 genes during senescence has a protective role to retain viability during this fundamental developmental process. WDS1 and WDS2 gene expression in wild-type Arabidopsis leaves infiltrated with $0.5 \mathrm{mM}$ salicylic acid was increased $48 \mathrm{~h}$ after induction. By using the pathogen-derived cell death elicitor FB1, we found that the WDS2 is a novel gene important for plant cell death signaling related to defense responses. WDS2 is predicted to be located in the nucleus and is thus likely to act as a regulator of nuclear gene expression. Our work has indicated the complexity of signalling pathways that involve WDS genes. Further study will help delineate the pathways and functions of WDS genes in senescence and in plant responses to stresses.
\end{abstract}




\section{Chapter I}

\section{Introduction}

Programmed cell death (PCD) has been well studied in animals, where it is called apoptosis (Krishnamurthy et al., 2000), while the mechanisms and pathways that regulate PCD in plants remain poorly understood (Lim et al., 2005). Plant PCD or animal apoptosis involve the same morphological and biochemical features, which are defined as physiological processes that involve the selective elimination of unwanted cells. It plays an important role in cell and tissue homeostasis, cellular differentiation, tissue sculpting, and disease resistance (Lam et al., 1999; Lim et al., 2005; Nood'en, 1988). This process takes place in plants for example, during developmental processes, such as gametogenesis, endosperm development, trachery element differentiation, and leaf senescence.

\subsection{PCD in different categories of plant cells}

In plants, the cell death mechanism has been studied in four categories: I) cells that die after performing a specific function, II) cells that die throughout terminal differentiation into specialized cell types, III) cells that are subjected to biotic and abiotic stresses, and IV) cell that are already unable to function from the beginning (Krishnamurthy et al., 2000). The following is a description of the analyses done on these four categories of cell death.

In the first category, cells that undergo cell death after performing their function have a similar mechanism of PCD to that of animal apoptosis. It was found that they share common characteristics, such as cytoplasmic condensation and shrinkage, general cell shrinkage, presence of effector proteases, reactive oxygen 
species (ROS) production, increase in cytosolic calcium, phosphorylation / dephosphorylation changes, chromatin condensation, and activation of endonucleases causing DNA fragmentation (Fukuda, 1997). The latter characteristic was measured by electrophoretic ladder formation and terminal deoxynucleotidyl transferase d-uridine triphosphate nick end labeling (TUNEL) detection where the size of the DNA fragments obtained was around 180 bp (Fukuda, 1997).

The second category includes tracheary elements (TEs), scelrenchyma fibres, sclerids and cork cells, which all undergo significant morphological changes during cell death. These cells die so that the cytological events associated with cell death are oriented towards making them persist and function until the end of the life of the plant. They exhibit cell enlargement and elongation during PCD. They do not show cell shrinkage, which is common in all other cells that undergo PCD. The nuclei of the cells are metabolically very active and undergo endoduplication and polytenic changes throughout the differentiation process. They are found to be transcriptionally extremely active and are responsible for the production of several chemicals that constitute a significant fraction of the persisting specialized secondary cell wall. These cells have proteases, thought to function in degrading cytoplasmic proteins, which are then recycled for use in organizing the specialized secondary wall (Fukuda, 1997). These cells also contain endonucleases causing DNA fragmentation.

The third category includes cells that are subjected to different abiotic and biotic stresses resulting in a hypersensitive response (HR). This category is the most studied category in plants. Studies have indicated that among a population of cells subjected to environmental stresses, there may be cells that are undergoing PCD, 
while others are depending on the strength of other stress factors and proximity of the cell to the stress agent. This is shown by the extent of cytological variations during stress-induced cell death in plants. Other stress-related PCD work have indicated that the overall changes observed may be due to PCD, which appear as necrotic in plant tissue (Krishnamurthy et al., 2000).

Finally, for the fourth category, a failure occurs in the initial stage of plant development due to injury or any other reasons leading to cell damage. There is not enough research that has been carried out to determine the mechanisms of cell death and physiological roles. Krishnamurthy et al.( 2000) indicated that the nonfunctional stamens in male flowers and nonfunctional carpel primordial cell in female flowers and/or nonfunctional cells formed during embryoid initiation in culture cells are examples of this type of cell death (Krishnamurthy et al., 2000). There is not much evidence to support this category and so definite conclusions cannot be made.

\subsection{PCD and leaf senescence}

Leaf senescence is the end of life span of leaf development, which is a complex process that is controlled by multiple developmental and environmental signals and is marked by induced expression of a large number of different genes (Guo et al., 2004). It is clearly marked by leaf colour change, which is associated with active physiological and biochemical processes such as chlorophyll breakdown, RNA and protein degradation, and translocation of nitrogen, carbon nutrients, and minerals from the senescing leaves to other parts of the plants. In other words, leaf senescence is the descent of age-dependence in plant development at the cellular, tissue, organ, or organism level, leading to death or the final stage of leaf 
development (Nood'en, 1988). Therefore, even though the initiation of leaf senescence is a lethal process, it can be seen as beneficial for the plant. It significantly contributes to the fitness of entire plants promoting most favorable production of offspring and better survival of plants in their given temporal and spatial functions. Consequently, it is considered an evolutionarily selected developmental process and an important stage in the plant life cycle (BuchananWollaston et al., 2003; Lim and Nam, 2005). However, leaf senescence in agricultural aspects plays an essential role in limiting crop yield in plants by limiting the growth phase. Moreover, it may cause post harvest decaying such as leaf yellowing and nutrient loss in vegetable crops. Therefore, the study of this process not only improves our understanding of the basic biological mechanisms, but also provides us with means to improve crop yield and quality.

Onset of leaf senescence is essentially controlled by developmental age. Nevertheless, it is influenced by a variety of internal and environmental signals. The environmental factors that manipulate leaf senescence include abiotic and biotic factors. The abiotic factors are drought, nutrient limitation, temperature extreme, and oxidative stress by UV-B irradiation or ozone, for example. The biotic factors are pathogen infection and shading by other plants (Lim and Nam, 2003). Plant growth and development can be significantly altered under these critical environmental conditions. Leaf senescence involves cell death that is influenced by age under the control of endogenous and environmental factors. Programmed cell death (PCD) is a self-destructing cellular system activated by internal or external factors and mediated throughout an active genetic program (Quirino et al., 2000). Since cell death in leaf senescence is influenced by many active genetic programs, the cell death occurring 
in leaf senescence is a type of PCD (Cao et al., 2003). A leaf is composed of many cell types. The mechanism of cell death in leaf senescence initiates from mesophyll cells and then proceeds to other cell types. Furthermore, it appears that cell death does not occur consistently, but rather begins with a restricted area of early dying cells and after that spreads through the entire leaf (Cao et al., 2003). In most plants, PCD is also involved in the development of tracheary elements, germination-related degeneration of aleuron layer cells, and pathogen-induced hypersensitive response (HR) (Lara et al., 2004; Van Doorn, 2005). Some features of PCD in leaf senescence are distinctive from other types of PCD. First, leaf senescence involves an organ level cell death that includes the whole leaf, while other types of PCD require rather localized cell death or take place in limited tissues and cell types. Second, the rate of cell death during leaf senescence is slower than that in other types of PCDs. Third, the molecular and biological function of PCD in leaf senescence is characterized by remobilization of nutrients from the leaf to other part of organs (Van Doorn and Woltering, 2004). Leaf tissue is the most important photosynthetic organ in plants. Therefore, the optimal use of nutrients accumulated through photosynthesis and nutrient metabolism is important for the strength of the plant and for crop yield. The slow degeneration of cells throughout leaf senescence may ensure effective remobilization of nutrients (Van Doorn and Woltering, 2004).

\subsection{PCD and plant disease resistance}

Plants have evolved multiple mechanisms to defend themselves against attacks of bacteria, viruses, fungi, oomycetes, nematodes and insects. Disease resistance in higher plants sometimes occurs in a 'gene-for-gene' mode, in which a plant expressing a specific resistance $(R)$ gene recognizes a pathogen strain 
expressing a corresponding effector (avirulence) gene (avr) and stimulates defense responses (Kirankumar et al., 2002). This type of interaction has been proposed to involve four different steps: (1) delivery of a pathogen-produced elicitor molecule to the plant cell; (2) identification of this signal molecule by the plant cell; (3) signal transduction, which involves many pathways; and (4) the activation of defence responses (Ynog-Qiang and Gregory, 1998). To date, $R$ genes have been identified that encode resistance to many pathogen types with very various lifestyles, outside or inside the plant cell (Bent, 1996).

Higher plants have multiple defense responses (Lamb et al., 1994). One of them is called the hypersensitive response (HR), which results in plant cell death at the site of pathogen attack that can limit pathogen ingress (Hammond-kosack \& Jones, 1996). In the past fifteen years, there has been considerable progress in the study of its role in plant defense (Jones, 2001; Lam et al., 1999). Two major types of cell death can result when plants are inoculated with a pathogen: the rapid hypersensitive response (HR), which is typically associated with gene-for-gene resistance, and a slower form of death associated with disease. Hypersensitive cell death occurs at the site of attempted attack by an avirulent pathogen, and the hypersensitive response leads to the formation of necrosis that is clearly delimited from surrounding healthy tissues. HR cell death is an active process in which the accumulation of $\mathrm{O}_{2}$ - and $\mathrm{H}_{2} \mathrm{O}_{2}$ leads to an elevation in cytosolic $\mathrm{Ca}^{2+}$ and triggers a protein kinase-mediated cell death process (Levine et al., 1996). Certain mutations in maize and Arabidopsis cause the spontaneous appearance of lesions resembling HR lesions (Lamb and Dixon, 1997), suggesting that HR cell death is under genetic control. Also, localized inoculation of Arabidopsis with an avirulent strain of 
Pseudomonas syringae leads to hypersensitive response and also triggers lowfrequency cell death in uninoculated leaves (Danon at el., 2000). This cell death in uninoculated leaves begins at approximately the same time as cell death in primary HR. Cell morphology studies and TUNEL (terminal deoxynucleotidyl transferasemediated dUTP nick end labelling) experiments suggest that cell death in uninoculated leaves is also PCD (Pennel and Lamb, 1997). The possibility that PCD occurs in uninoculated leaves which may contribute to systemic disease resistance, would represent a novel function for PCD.

\subsection{Genetic approaches in the analysis of PCD}

Two main genetic approaches have been taken to study of PCD in senescence and disease resistance. First, genes can be determined by the isolation and characterization of mutants (Buchanan-Wollaston et al., 2003). Second, determination of differential gene expression to identify senescence-regulated genes and molecular cell death markers. The rapid progress in genomics and bioinformatics resources and the use of the model plant species Arabidopsis thaliana has greatly facilitated these approaches. Arabidopsis is considered one of the best model plants for the molecular genetic study of leaf senescence and disease resistance due to many reasons: first, Arabidopsis thaliana has a short life cycle; second, its leaves undergo clear developmental stages and demonstrate a reproducible senescence program; third, the vast Arabidopsis genomic resources accelerate the functional analysis of senescence-assocated genes (SAGs) (Bleecker and Patterson, 1997; Buchanan-Wollaston et al., 2003; Lim et al., 2003).

Microarray technology and the availability of publically available genomic databases has also significantly accelerated the discovery and functional analysis of 
novel genes. Zhu and Wang (2000) designed their microarray experiment to analyze the gene expression levels at three different stages of leaf development by using Affymetrix Arabidopsis GeneChips, which carried probes for around 8000 Arabidopsis gene. They found approximately 1400 genes that showed relative changes in expression patterns during leaf development, senescence and defense responses.

\subsection{Salicylic acid has a role in regulating gene expression during leaf senescence}

As described earlier, leaf senescence is a complicated process that is controlled by multiple internal and external factors and is marked by induced expression of many genes. Many studies have shown that the salicylic acidsignalling pathway has a role in the control of gene expression during leaf senescence. Salicylic acid (SA) is also known as a major plant growth regulator that is involved in defense against pathogens (Appendix B).

However, a recent study in programmed cell death identified a role of SA in the initiation of leaf senescence. In Arabidopsis thaliana, the endogenous SA concentration was found to be four times higher in senescencing leaves compared to younger leaves (Morris et al., 2000; Ryals et al., 1996; Ward et al., 1991). Senescence at this stage appears to involve the up-regulation of many senescenceassociated genes (SAGs). Gene expression of SAGs such as PR1a (LSC94), chitinase, and SAG12 are altered in Arabidopsis plants defective in the salicylic acid signalling or biosynthetic pathway (pad4 mutants, and NahG transgenic plants) (Morris et al., 2000). Morris et al. (2000) also showed that the expression of the PR1a (LSC94) gene is strongly induced in green leaves treated with SA. 
Nevertheless, the SAG12 gene showed no induction, which indicated that expression of SAG12 is not solely dependent on SA. In addition, Arabidopsis leaves from pad 4 mutants have reduced cell death compared to the wild type (Morris et al., 2000). In this mutant, changes in gene expression patterns were accompanied by reduced necrosis indicating that there might be a genetic control switch regulating the transition from senescence to cell death. It is possible that senescing leaves are sustained long enough for efficient reclamation of nutrients. After that, individual cells are damaged by PCD. Also, the recessive pad4 mutation suggests that NPR1 and PAD4 are directly involved in SA signaling. Pad4 mutant was also isolated and characterized by screening for increased susceptibility to virulent strains (Jirage et al., 1999). After pathogen infection, pad4 mutant has reduced PR-1 expression and salicylic acid accumulation. Therefore, since the pad4 mutant has reduced defense responses when treated with pathogens that elicit a strong hypersensitive response (HR), PAD4 is considered to increase weak salicylic acid signals (Jirage et al., 1999).

To date, few studies have addressed the regulatory network governing leaf senescence and coordinating with plant defense signaling pathways in Arabidopsis (Bekir, et al., 2007; Li et al., 2004). Morris et al. (2000) present a critical model of signalling networks leading to alterations in gene expression during leaf senescence. Morris and colleagues proposed that when the onset of senescence is induced, a number of different signalling factors (senescence-enhanced factors, SEFs) are involved in controlling the genes that carry out the senescence process. SA is a signalling factor essential for the expression of certain senescence-enhanced genes, some of which (LSC94 and LSC222) are probably independent of any other factors. 
However, other genes are independent of SA and at the same time are expressed in tissues that are not undergoing senescence (e.g. LSC54, LSC7 and LSC30) (Morris et al., 2000). The reason for enhanced-expression of these genes during senescence requires further study.

Jose et al. (2008) stated that an internal factor such as Acetylsalicylic acid (ASA) behaves as an agent regulating PCD. ASA is derived from the plant hormone salicylic acid that activates the expression of a variety of pathogenesis-related (PR) genes and induces resistance to a variety of pathogens. To illustrate, an important progress in understanding of SA-mediated signaling pathways was the isolation and characterization of Arabidopsis npr1 mutant (Kinkema et al., 2000; Yu, et al., 2001). This mutant failed to express and induce pathogenesis-related gene expression in response to salicylic acid. This suggests that NPR1 is directly involved in SA signaling.

\subsection{Fumonisin B1 (FB1)-induced cell death in Arabidopsis requires SA dependent signaling pathway}

FB1 is a sphingoid-like compound secreted from different species of fungi and often associated with plant fungal diseases. The fumonisins have been shown to be pathogenicity or virulence factors in Fusarium moniliforme (Asai et al., 2000). Gilchrist et al. (1998) found that FB1 enhances PCD in wild-type protoplasts. Nevertheless, FB1 only slightly affects the viability of protoplasts isolated from the Arabidopsis NahG mutant, in which SA is degraded, and from the Arabidopsis pad4 mutant, in which SA signal amplification progress is impaired. Thus, treating Arabidopsis plants with FB1 will initiate degradation of the nuclear DNA membrane, preceding the loss of membrane integrity. Although little is known about its target 
and the nature of its activity in plant tissues, FB1-induced cell death is dependent on active transcription and translation factors and reversible protein phosphorylation (Asai et al., 2000; Chivasa et al., 2005). It has been utilized as the basis of model systems to investigate cell death in pathogen-free-conditions, which is advantageous as it avoids both the confounding effects of pathogen growth in experimental media and tissues and the necessity of maintaining and propagating pathogenic organisms (Chivasa et al., 2005) In addition, FB1-induced cell death in Arabidopsis requires SA-, jasmonic acid (JA) -, and ethylene (Et)-mediated signaling pathways.

\subsection{Mannitol accumulation in response to abiotic and biotic stresses}

Plants have a significant ability to deal with highly variable environmental stresses, including cold, drought, and hyperosmotic stress. Today, these stresses represent the major cause of crop loss worldwide such as reducing average yields for most major crop plants by more than $50 \%$. On the contrary, the estimated yield loss caused by pathogens is found to be around $10 \%$ to $20 \%$. Significant progress has been study to understand and manipulate abiotic stress responses (Galaud et al., 1997; Kiedrowski et al., 1992; Williamson et al., 1995; Kerps et al., 2002; Loescher et al., 1992).

Mannitol, a six carbon sugar alcohol, has previously studied by plant scientists. They found that species that metabolize mannitol have several advantages over those that completely translocate sugars. One advantage is used as hyperosmotic stress indicator. Another advantage is probably play an important role in plant responses to pathogen attack. Therfore, mannitol metabolism may play roles in plant responses to both biotic and abiotic stresses. The molecular and 
genetic basis of plant tolerance or sensitivity to hyperosmotic stress is poorly understood. (Chen et al., 2005; Kerps et al., 2002; Kiedrowski et al., 1992 ;Williamson et al., 1995; Loescher et al., 1992 ).

\subsection{Plant MAPK cascades play a role in leaf senescence}

Today, biologists consider signal transduction as one of the most widely studied fields. Extracellular signals from the surface of a cell are translated into an intracellular response that involves complex signaling pathways. These signaling actions eventually control such cellular responses as proliferation, differentiation, secretion, and PCD. To illustrate, signal transduction cascades are activated by the binding of extracellular ligands (e.g. biotic and/or abiotic factors) to cell-surface receptors. These receptors transducer the extracellular stimulus to the intracellular fluid, where the signal activates other signaling factors such as the mitogenactivated protein kinase (MAPK) signaling pathways"(Hopkins et al., 2007; Murray, 1998; Xiong et al., 2005). This pathway plays a significant role in signal transduction in animal and plant cells (Champion et al., 2004). Plants are equipped with this defense system which consists of MAPKs, MAPK kinases (MAPKKs) and MAPK kinase kinases (MAPKKKs). There are twenty MAPKs, 10 MAPKKs, 60 MAPKKKs, 15 kinases of the Raf family in Arabidopsis (MAPKK Group, 2002). Doczi et al., (2007) found that MPK1, MPK2, MPK7, and MPK14 were identified as downstream substrates of MKK3, as revealed by yeast two-hybrid. However, a complete identification of MAPK cascade in Arabidopsis has been a challenging problem (Champion et al., 2004; Doczi et al., 2007; MAPKK Group, 2002; Zhou et al., 2009). 
The pathway of MAPK cascades is associated with different physiological, developmental, and hormonal responses. In addition, molecular and biochemical studies have indicated that MAPKs cascades are associated with many factors such as pathogen infection, wounding, temperature, drought, high salinity, and reactive oxygen species (Champion et al., 2004; MAPKK Group, 2002; Tena et al.,2001; Zhou et al., 2009). The MAPKK is stimulated by an upstream MAPKKK and, in turn, triggers the MAPK. Then, the stimulatory MAPK activates various other protein kinases, catalyses the phosphorylation of cytoskeletal components, or regulate the function of transcription factors (Hirt, 1997). The MAPK pathways also integrate signal convergence and divergence, transmit positive and negative regulatory mechanisms, and interact with scaffold proteins. Most of the substrates for stressstimulated MAPKs in animal and yeast cells are transcription factors (Davis, 2000). Therefore, the activation of MAPK cascades leads to the phosphorylation of transcription factors, which stimulate gene expression. Similar roles in plants are supported by experiment in Liu et al., (2000). They identified a MAPK that moves into the nucleus upon activation in parsley cells treated with Pep25 elicitor.

There is not much evidence showing that MAPK cascades play any roles in controlling leaf senescence. However, Zhou et al, (2009) verified the interaction of a new signaling pathway in Arabidopsis that entails both MKK9 and MPK6 in leaf senescence at the biochemical, physiological, cell and molecular genetic levels (Zhou et al., 2009). These genes have kinase activities, and the loss-of-function and gain-of-function analyses have revealed that MKK9-MPK6 cascade positively regulates leaf senescence in Arabidopsis (Zhou et al., 2009). 


\subsection{Will Die Slowly (WDS) family members}

Hollmann et al, (2002) described the characterization of the essential Drosophila melanogaster will die slowly (wds) gene. They found that the predicted amino acid sequence contains seven WD40 repeats (Hollmann et al., 2002). These structural and mechanistic aspects of WD40 repeats are described below.

WD40-RPs (repeat proteins) play fundamental roles in such distinct mechanisms as signal transduction, nuclear export, cytoskeletal assembly, vesicular traffic and fusion, and RNA synthesis/processing (Letunic et al., 2008). In addition, WD40-RPs are intimately involved in chromatin modification and transcriptional mechanisms (Dan-Qiao et al., 2005; Letunic et al., 2008; Myoung et al., 2006; Neer et al., 1994). Moreover, WD40-RPs play a key role in different cellular and organismal processes such as cell division and cytokinesis, apoptosis, light signaling and vision, cell motility, flowering, floral development, and meristem organization (Neer et al., 1994).

Furthermore, WD40-RPs typically have four to ten repeat units, each composed of approximately 44-66 amino acids which form core and variable regions. Each repeat unit ends with the dipeptides Gly-His $(\mathrm{GH})$ at the $\mathrm{N}$ termini and Trp-Asp (WD) at C termini (Smith et al., 1999). The structure of the WD40-repeat proteins has been determined for a mammalian $G B$ subunit of heterotrimeric GTPases (Letunic et al., 2008; Hollmann et al., 2002). The repeated Trp-Asp units form a series of four-stranded, and antiparallel ß-sheets, which fold into a higherorder structure termed a ß-propeller. Chothia et al. (1997) stated that the structure of WD40-RPs can be visualized as a short, open cylinder where the strands form the walls and al least four repeats together are required to form a ß-propeller. 
Where studied, WD40-RPs domains within proteins work as sites for interaction with other proteins, which allows for three general functional roles. First of all, the interaction of WD40-repeat proteins within one protein can provide binding sites for more than one other protein, as well as promote transient interaction amongst these other proteins. Secondly, WD40-RPs have a potential role as an integral component of protein complexes. Finally, WD40-RPs act as a modular interaction domain of larger proteins (Letunic at el., 2008; Tullio-Pelet et al., 2000; Van der-Voorn and Ploegh, 1992).

Mutation of WDS gene in Drosophila led to lethality in the larval stages (Shannon et al., 1972). The role for WDS in Drosophila development has not been further investigated. The lethality of mutant alleles in gynandromorphs and germ cell clones indicates that the gene is important in most of the cells and the presence of WD40 repeats is indicative of protein-protein interactions (Hollmann et al., 2002; Komachi et al., 1997; Tie et al., 1998). Five predicated proteins in Arabidopsis thaliana shows significant amino acid sequence similarity to WDS of Drosophila melanogaster (Xiong, 2007). The Drosophila homolog has been implicated in cell death and this provided the initial rationale for testing the role of Arabidopsis WDS2.

Previously, Xiong (2007) identified and described the five-member gene family, Will Die Slowly (WDS), of Arabidopsis (Figure 1.1). The WDS proteins contain seven WD40 repeats (also called Trp-Asp repeat) (Figure 1.1). There are around 269 different proteins in Arabidopsis that have WD40 repeats, representing distinct cellular and biochemical pathways (van Nocker and Ludwing, 2003). 
Figure 1.1: Phylogenetic tree (a) and domain structure (b) of WDS family members. Protein sequences of WDS1-5 were aligned using ClustalW version 1.83. The phylogenetic tree was generated from this sequence alignment indicating that WDS2 is mostly related to WDS1. Sequence analysis in SMART showed that the protein of WDS1, WDS2, and WDS3 contain three conserved motifs: the 33-residue LisH motif, CTLH domain and seven WD40 repeat (Letunic at el., 2008; Smith et al., 2000). 

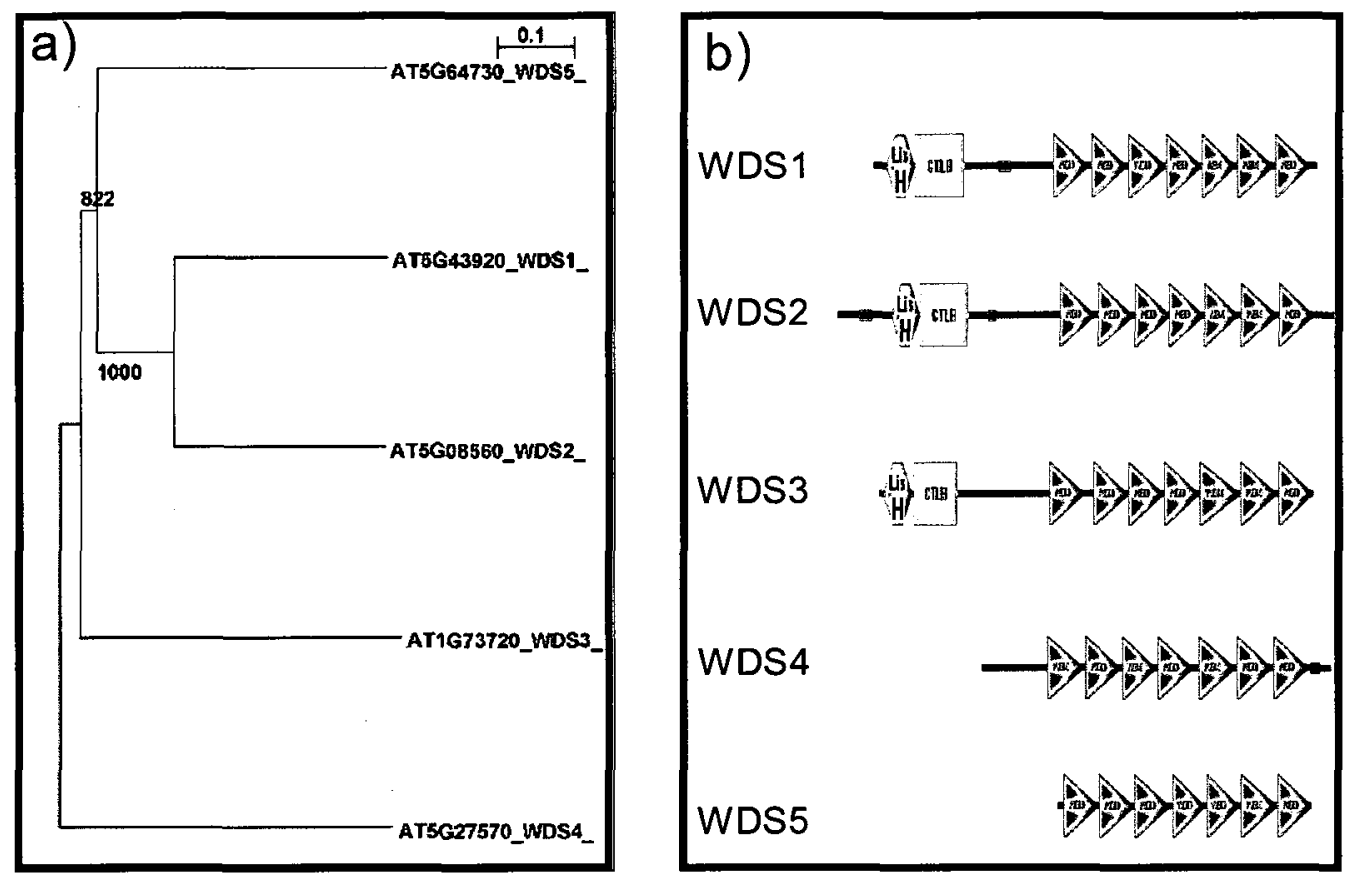


\subsection{Hypothesis and Objectives}

In this project, we characterized the WDS2 gene and analyzed its potential functions in cell death and disease resistance. The WDS2 gene was initially investigated using the genomic tools available in the Arabidopsis Information Resource (TAIR). Furthermore, I studied the nature of members of the WDS gene family and determined the WDS1 and WDS2 gene expression profiles during leaf senescence and PCD. As mentioned earlier, Xiong (2007) studied WDS1 and found that a knockout of WDS1 accelerates the induction of SAG12 expression triggered by FB1, indicating a regulatory role of WDS1 in stress-induced senescence. In addition, WDS1 expression was found to up-regulated by SA as well as the overexpression of WDS1 in Arabidopsis enhances the tolerance to osmotic stress. These results supported her hypothesis that the WDS1 gene is involved in cell death progression triggered by both developmental and stress signals in Arabidopsis. Therefore, in this project, characterizing the related WDS2 gene including studying the phenotype of the wds2 mutant, and a double mutant of wds1 wds2. One of the most important objectives in this study was to investigate how WDS2 is coordinately regulated during this process. For example, is WDS2 involved in the FB1 and SA pathway?

My hypothesis is that WDS2 has an important role in leaf senescence and plant development by regulating PCD. My goals were:

(1) phenotypic and functional analysis of WDS2 in knockout lines;

(2) create a double mutant between wds1 and wds2 for phenotypic and functional analysis; 
(3) construct tagged (GFP) fusions of WDS2 for subcellular localization by confocal microscopic analysis;

(4) study the function of WDS2 in SA pathways, responses to hyperosmotic stress, and treatment with the fungal elicitor Fumonisin B1. 


\section{Chapter II}

\section{Materials and Methods}

\subsection{Plant materials and growth conditions}

Arabidopsis T-DNA insertion lines of WDS2 in Columbia-0 (Col-0) ecotype background were obtained from the Arabidopsis Biological Resource Centre (ABRC) (Ohio State University). Plants were grown either in a long day condition (16 hours of light, 8 hours of dark) or a short day condition ( 8 hours of light, 16 hours of dark) at $22{ }^{\circ} \mathrm{C}$ in growth chambers (ENCONAIR Technologies Inc, Winnipeg, Monitoba). Seeds were surface sterilized for $2 \mathrm{~min}$ in $70 \%$ ethanol and then soaked for $8 \mathrm{~min}$ in sterilization solution ( $25 \%$ Bleach $v / v$ and $0.01 \%$ Triton $X-100(v / v)$. Seeds were then rinsed 10 times with autoclaved water and then suspended in $0.1 \%$ agarose solution. For the growth and development experiments, sterilized seeds were sowed directly onto autoclaved soil (BM1, Montreal, Quebec, Canada). For phenotypic and hyperosmotic stress analyses, seeds were germinated on petri plates containing $1 \mathrm{x}$ Murshige and Skoog (MS) basal medium (Sigma, St Louis, MO, USA), 3.0\% sucrose (w/v) and $0.8 \%$ agar (w/v) (EMD Chemicals Inc. Darmstadt, Germany). The $\mathrm{pH}$ of

the media was adjusted to 5.8 . The plates were kept in the dark at $4^{\circ} \mathrm{C}$ for 4 days. The plates were then moved to the growth chamber for 7-10 days. The seedlings were transferred to autoclaved soil at the 2-rosette leaf stage. 


\subsection{Genotyping loss-of-function T-DNA lines}

Two different SALK T-DNA insertion lines (SALK_095495 and SALK_100917) of wds2 mutant were characterized (Alonso et al., 2003). Arabidopsis thaliana ecotype Columbia-0 (ColO) is used as the wild type control for these lines. Extract-N-Amp TM plant PCR kit (Sigma Aldrich, Oakville, ON, Canada) was used for DNA extraction. Leaf tissues (0.5-0.7 cm long) were collected in $1.5 \mathrm{~mL}$ Eppendorf tubes and frozen in liquid nitrogen. A $100 \mu \mathrm{L}$ aliquot of extraction solution was added to the collection tube. The tube was then incubated at $95^{\circ} \mathrm{C}$ for $10 \mathrm{~min}$. After that, $100 \mu \mathrm{L}$ of dilution solution was added and the sample was then stored at $4^{\circ} \mathrm{C}$. The following reagents were then added to $0.5 \mathrm{~mL}$ PCR microcentrifuge tube: $1 \mu \mathrm{L}$ PCR reagent, $10 \mu \mathrm{L}$ Extract-N-AMP PCR reaction, $3 \mu \mathrm{L}$ of $10 \mu \mathrm{M}$ forward primer, $3 \mu \mathrm{L}$ of $10 \mu \mathrm{M}$ reverse primer and $3 \mu \mathrm{L}$ leaf disk extract. The homozygous mutant was identified by using PCR with primers that flank the T-DNA insertion under the following conditions: 94 ${ }^{\circ} \mathrm{C}$ for $3 \mathrm{~min} ; 30 \mathrm{~s}$ at $94^{\circ} \mathrm{C} ; 30 \mathrm{~s}$ at $59^{\circ} \mathrm{C} ; 30 \mathrm{~s}$ at $72^{\circ} \mathrm{C}$ for 34 cycles; and then $10 \mathrm{~min}$ at $72^{\circ} \mathrm{C}$. The primer sequences were: 5'-CAAAACTCAATTCAGGCAAGC-3' (LP) and 5'-CTGATGAGAAGGCTGTCAAGG-3' (RP) for SALK_095495, and 5'CAAAACTCAATTCAGGCAAGC-3' (LP) and 5'-CCATTAAGCTGTTTCTGCAGC-3' (RP) for SALK_100917. The presence of the T-DNA insertion was confirmed using gene specific primers and a primer designed to the left border (either LBa1 or LBb1) of the T-DNA insertion. The primer sequence of LBa1 was 5'TGGTTCACGTAGTGGGCCATCG-3' and LBb1 primer was 5'GCGTGGACCGCTTGCTGCAACT-3'. 
A complete loss-of-function of wds1 and wds2 were obtained as described above. A loss-of-function mutant of wds1 wds2 double mutant was generated by crossing the $w d s 1$ and $w d s 2$ mutants and genotypic identification in the F2 generation.

\subsection{Confirmation of loss-of-function using reverse transcriptase PCR (RT-PCR) to monitor transcript levels}

Total RNA was extracted from the loss-of-function SALK T-DNA lines after growth for $\sim 10$ days on solid media (as described earlier in section 2.1). TRIzol Reagent kit (Invitrogen, Carlsbad, CA, USA) was used for RNA extraction according to manufacturer's protocol. Leaf tissue $(100 \mathrm{mg})$ was homogenized in $1 \mathrm{~mL}$ of TRIzol. The homogenized sample was incubated for $5 \mathrm{~min}$ at RT to permit the complete dissociation of nucleoprotein complexes. An aliquot of $200 \mu \mathrm{L}$ of chloroform was then added to the sample, mixed vigorously by hand for 15 seconds, and incubated at RT for 2-3 min. The sample was centrifuged for $15 \mathrm{~min}$ at $12,000 \times \mathrm{g}$ at $4^{\circ} \mathrm{C}$. Following centrifugation, the mixture separated into a lower, phenol-chloroform phase, an interphase, and a colorless upper aqueous phase. RNA remains exclusively in the aqueous phase. The volume of the aqueous phase was about $60 \%$ of the volume of TRIzol reagent used for homogenization. The aqueous phase was transferred into a fresh tube and $500 \mu \mathrm{L}$ of isopropyl alcohol was added. The sample was incubated for $10 \mathrm{~min}$ at RT and centrifuged for $10 \mathrm{~min}$ at $12,000 \times \mathrm{g}$ at $4^{\circ} \mathrm{C}$. The RNA precipitate formed a gel-like pellet on the side and bottom of the tube. The supernatant was removed and the RNA pellet was washed once with $1 \mathrm{~mL}$ of $75 \%$ 
ethanol (diluted with DEPC water). The sample was mixed by vortexing and centrifuged $5 \mathrm{~min}$ at $7,500 \times \mathrm{g}$ at $4^{\circ} \mathrm{C}$. At the end of the procedure, the RNA pellet was air-dried for $5 \mathrm{~min}$. The pellet was dissolved in $50 \mu \mathrm{L}$ of RNase-free water and stored at $-80^{\circ} \mathrm{C}$.

After TRIzol extraction, Deoxyribonuclease I kit (amplification grade, Invitrogen, Carlsbad, CA, USA) was used to eliminate genomic DNA contamination in the sample. The following was added to an RNase-free, $0.5 \mathrm{~mL}$ microcentrifuge tube on ice: 1-5 $\mu \mathrm{g}$ RNA sample, $1 \mu \mathrm{L}$ 10X DNase I reaction buffer (100mM Tris$\left.\mathrm{HCL}(\mathrm{pH} 7.5), 25 \mathrm{mM} \mathrm{MgCl}_{2}, 5 \mathrm{mM} \mathrm{CaCl}_{2}\right), 1 \mu \mathrm{L}$ of $1 \mathrm{U} / \mu \mathrm{L}$ DNase I, and DEPCtreated water to $10 \mu \mathrm{L}$. The sample was then incubated for 15 min at RT. DNase I was inactivated by addition of $1 \mu \mathrm{L}$ of $25 \mathrm{mM}$ EDTA solution to the reaction mixture. The sample was heated $10 \mathrm{~min}$ at $65^{\circ} \mathrm{C}$.

Next, the Cloned AMV First-Strand cDNA Synthesis Kit (Invitrogen, Carlsbad, CA, USA) was used for CDNA synthesis according to the manufacturer's protocol. A master mixture of $4 \mu \mathrm{L}$ of $5 x \mathrm{cDNA}$ synthesis buffer $(250 \mathrm{mM}$ Tris acetate $(\mathrm{pH} 8.4)$, $375 \mathrm{mM}$ potassium acetate, $40 \mathrm{mM}$ magnesium acetate, stabilizer, $20 \mu \mathrm{g} / \mathrm{mL} \mathrm{BSA}$ ), $1 \mu \mathrm{L}$ of $0.1 \mathrm{M} \mathrm{DDT}, 1 \mu \mathrm{L}$ of RNaseOUT $(40 \mathrm{U} / \mu \mathrm{L}), 1.5 \mu \mathrm{L}$ of DEPC-treated water and

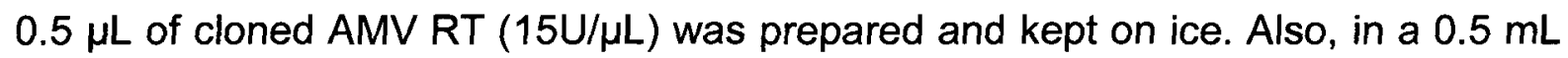
tube, the following components were mixed: $1 \mu \mathrm{L}$ of $50 \mu \mathrm{M}$ Oligo(dt) ${ }_{20}, 1-5 \mu \mathrm{g}$ RNA sample, $2 \mu \mathrm{L}$ of $10 \mathrm{mM}$ dNTP mix and DEPC-treated water to $12 \mu \mathrm{L}$. The mixture was incubated for $5 \mathrm{~min}$ at $65^{\circ} \mathrm{C}$. Eight $\mu \mathrm{L}$ of the master mixture was added to the above $0.5 \mathrm{~mL}$ reaction tube. Then, the reaction tube was transferred to a thermal cycle and heated for $48 \mathrm{~min}$ at $48^{\circ} \mathrm{C}$, and then for $5 \mathrm{~min}$ at $85^{\circ} \mathrm{C}$. RNA and DNA 
quantity was measured using a Nanodrop ND-1000 spectrophotometer (Thermo Fisher Scientific, Wilmington, USA). The primers used for RT-PCR were, 5'ATCGCCAGTGGAAGTGAGGATTC-3' and 5'-AGTTCAGTGGTTTGTTCGGTTTGC3' for WDS1; 5'-CCAAGGGGATGACGAAACTA-3' and 5'GGAAACCGATTCTGTGCAAT-3' for WDS2; 5'- AGACGCTGGGATGTTGATTC-3' and 5'- CATGGCCTGGTAGCTCAACT-3' for WDS2; 5'CGGTTAGCGTTGGAATTGAAGGAG-3' and 5'TCCGTTAGTAGATTCGCCGTATCC-3' for SAG12; CCTCATGCCATCCTCCGTCTTG-3' and 5'-TTCCATCTCCTGCTCGTAGTCAAC-3' for ACTIN2 (At3g18780); and 5'-TTCTTCCCTCGAAAGCTCAA-3' and 5'AAGGCCCACCAGAGTGTATG-3' for PR-1 (At2g14610). PCR was carried out under the following conditions: $94^{\circ} \mathrm{C}$ for $3 \mathrm{~min} ; 30 \mathrm{~s}$ at $94^{\circ} \mathrm{C}, 30 \mathrm{~s}$ at $59^{\circ} \mathrm{C}$, and $30 \mathrm{~s}$ at $72^{\circ} \mathrm{C}$ for 25 cycles; and then $10 \mathrm{~min}$ at $72^{\circ} \mathrm{C}$. All the primers were designed to amplify products in the range of $100-300 \mathrm{bp}$.

\subsection{Root length analyses}

Sterilized seeds of Col-0, wds1, wds2 and wds1 wds2 were sowed in vertical MS-agar-plate and kept in the growth chamber with long day condition. After 9 days, the root length $(\mathrm{cm})$ of the above seedlings plants was measured. 


\subsection{Treatment with Salicylic acid (SA) and chlorophyll content analysis}

Leaves from three-to-four-week-old plants (Col-0, wds1, wds2, and wds1 wds2) were collected, cut to squares of about $0.6-0.8 \mathrm{~mm}^{2}$ and then were treated with 0.5 $\mathrm{mM}$ and $2.0 \mathrm{mM}$ SA solution. These leaf discs were infiltrated by a vacuum pump for $20 \mathrm{~min}$ and then were placed upward on the filter paper in a Petri dish so that they were just covered by the SA solution. Water was used as a control. Samples after Oh, $24 \mathrm{~h}, 48 \mathrm{~h}$, and $72 \mathrm{~h}$ incubation were collected for various analyses.

Fresh tissues $(50 \mathrm{mg})$ from Col-0, wds1, wds2, and wds1 wds2 were collected after treatment. $1 \mathrm{ml}$ of $95 \% \mathrm{EtOH}$ was added to tissues and incubated at $65^{\circ} \mathrm{C}$ for 2 hours. The OD649 and OD665 were measured. The micromolar concentration of total chlorophyll per gram of fresh weight of tissue was calculated using the following equation:

Total micromoles [chlorophyll $a+$ Chlorophyll b] $=6.1$ OD665+ 20.04 OD649.

\subsection{Treatment with Fumonisin B1 (FB1)}

Approximately seven fully expanded leaves were harvested from 3-week-old plants. Detached leaves were infiltrated with three different concentrations of FB1 $(1 \mu \mathrm{M}, 2$ $\mu \mathrm{M}$ and $5 \mu \mathrm{M})$ as an elicitor to trigger cell death. After infiltration, leaves were incubated in FB1 solution in the growth chamber at $22^{\circ} \mathrm{C}$ under $16-\mathrm{h}$ light/8-h dark condition. Samples after $0 \mathrm{~h}, 24 \mathrm{~h}, 48 \mathrm{~h}, 72 \mathrm{~h}, 96 \mathrm{~h}$, and $120 \mathrm{~h}$ of incubation were collected for staining assays (section 2.7). 


\subsection{Trypan blue and aniline blue staining}

Cells of Arabidopsis rosette leaves undergoing cell death were photographed using an Axioplan 2 microscope (Carl Zeiss). Methods described by Tang et al. (1999) and Stone et al. (2000) were used with slight modifications. Falcon tubes containing the leaves were boiled at $95^{\circ} \mathrm{C}$ for $4 \mathrm{~min}$ and kept at room temperature for $20 \mathrm{~min}$ instead of $30 \mathrm{~min}$ for the detection of autofluorescent materials.

Arabidopsis rosette leaves were immersed in $10 \mathrm{~mL}$ of ethanol-lactophenol (2 volumes of ethanol and 1 volume of phenol-glycerol-lactic acid-water $(1: 1: 1: 1))$ that contained $0.05 \%$ trypan blue. The leaves were placed in $15 \mathrm{ml}$ Falcon tubes and covered with ethanol-lactophenol-trypan blue. The samples were incubated at $95^{\circ} \mathrm{C}$ for $4 \mathrm{~min}$ and then kept at room temperature for $20 \mathrm{~min}$. The staining solution was removed and $1.5 \mathrm{~mL}$ chloral hydrate destaining solution $(2.5 \mathrm{~g} / \mathrm{mL}$ of nano pure water) was added to each tube. The leaves were cleared for 2 days by replacing the destaining solution twice. After destaining, leaves were suspended in $50 \%$ glycerol and examined under Axioplan 2 microscope (Cark Zeiss) with white light.

Arabidopsis rosette leaves were immersed and vacuum-infiltrated in $10 \mathrm{~mL}$ of ethanol-lactophenol $(2: 1 \mathrm{v}: \mathrm{v})$ and then incubated at $60^{\circ} \mathrm{C}$ for $30 \mathrm{~min}$. Leaves were rinsed in $50 \%$ ethanol and stained overnight with aniline blue $(0.01 \%$ aniline blue powder in $150 \mathrm{mM} \mathrm{K}_{2} \mathrm{HPO}_{4}, \mathrm{pH}$ 9.5). Leaves were equilibrated in $50 \%$ glycerol and aniline blue staining was visualized using a UV epifluorescence (Axioplan 2 microscope, Carl Zeiss) with a DAPI filter (Scan range: $320-520 \mathrm{~nm}$ ). 
2.8 DNA construct for fusion of WDS2 with green fluorescent protein, transformation in to Agrobacterium tumefaciens, and transient delivery into plant cells

The CDNA of WDS2 was obtained from ABRC (Ohio State University). The primers used for amplification were At5g08560-FSall: 5'AGAGTCGACATGGGAGTTGTGGAGGATACTG-3' and At5g08560-RBamHI: 5'AGAGGATCCTCAATTCCCATTGCATCGGT-3'. Two different flanking restriction enzyme sites, Sall and BamHI, were introduced. Both the WDS2 and pVKH18::GFPN vector were digested using the corresponding restriction enzymes to generate 'sticky' ends. The cDNA fragments were ligated using T4 DNA ligase (Invitrogen, Burlington, Canada). The ligation mixtures were used to transform competent $\mathrm{DH} 5 \alpha \mathrm{E}$. coli to generate recombinant plasmid $p V K H 18:: G F P-W D S 2$. A total of $10 \mu$ of DNA per reaction was sent for sequencing (National Research Council of Canada, Saskatoon, SK). Then, the $p V K H 18:: G F P-W D S 2$ construct was transferred to Agrobacterium tumefaciens strain GV3101 using a modified freezethaw method. Agrobacterium tumefaciens strain GV3101 carrying the binary plasmid construct was streaked on LB plates (10 g/L tryptone, $5 \mathrm{~g} / \mathrm{L}$ yeast extract, $10 \mathrm{~g} / \mathrm{L}$ $\mathrm{NaCl}$ and $7 \mathrm{~g} / \mathrm{L}$ agar) with the added antibiotics (kanamycin $(50 \mu \mathrm{g} / \mathrm{mL}$ ), gentamycin $(25 \mu \mathrm{g} / \mathrm{mL})$ and rifampicin $(50 \mu \mathrm{g} / \mathrm{mL}))$ and incubated at $28^{\circ} \mathrm{C}$, and for 3 days. A single Agrobacterium colony was inoculated into $5 \mathrm{~mL}$ of sterilized LB medium (10 $\mathrm{g} / \mathrm{L}$ tryptone, $5 \mathrm{~g} / \mathrm{L}$ yeast extract and $5 \mathrm{~g} / \mathrm{L} \mathrm{NaCl}$ ) containing the same antibiotics and grown at $28^{\circ} \mathrm{C}$, and at $225 \mathrm{rpm}$ for 3 days. 


\subsection{Subcellular localization}

Cell cultures of Agrobacterium were grown for 3 days. Cells were collected in $1.5 \mathrm{~mL}$ Eppendorf tubes by centrifugation for $10 \mathrm{~min}$ at $1000 \mathrm{~g}$ at RT. Then, the supernatant was discarded and the pellets were resuspended in $1 \mathrm{~mL}$ of infiltration medium (500 mM MES, $20 \mathrm{mM} \mathrm{Na}{ }_{3} \mathrm{PO}_{4} \cdot 12 \mathrm{H}_{2} \mathrm{O}, 1 \mathrm{M}$ acetosyringone and $1 \mathrm{M} \mathrm{D}(+)$-glucose). The cells were pelleted again and then resuspended in $1 \mathrm{~mL}$ infiltration medium. The second wash with $1 \mathrm{~mL}$ infiltration medium was repeated once to remove any trace of antibiotics that may kill the leaves after infiltration. Following this, $0.3 \mathrm{~mL}$ of infiltration medium was injected by syringe into leaves of 5-week-old tobacco leaves. Subcellular localization was examined using an LSM 510 META confocal microscope (Carl Zeiss).

\subsection{Osmotic stress treatment}

Sterilized seeds of Arabidopsis thaliana Col-0 were sown in Magenta boxes containing MSagarmedia and plants were grown in a long day chamber. Sixteenday-old seedlings of Col-0 were sprayed with $0.6 \mathrm{M} \mathrm{D-mannitol}$ or water as a mock control. The boxes were transferred back to the growth chamber. Leaves were collected $0,6,12,24 \mathrm{~h}$ after treatment. The primers used for RT-PCR were: 5'CCAAGGGGATGACGAAACTA-3' and 5'-GGAAACCGATTCTGTGCAAT-3' for

WDS2; 5'-CCTCATGCCATCCTCCGTCTTG-3' 5'TTCCATCTCCTGCTCGTAGTCAAC-3' for ACTIN2; and 5'TGTCACACCGATGTTTAC-3' and 5'-GGTCGAATCTTTTAGAGTTAA-3' for $A D H$. Conditions of PCR were as follows: $94^{\circ} \mathrm{C}$ for $3 \mathrm{~min}, 30 \mathrm{~s}$ at $94^{\circ} \mathrm{C}, 30$ s at $59^{\circ} \mathrm{C}$, and 
$30 \mathrm{~s}$ at $72^{\circ} \mathrm{C}$ for 28 cycles; and then $10 \mathrm{~min}$ at $72^{\circ} \mathrm{C}$. For $A D H$, the annealing temperature was modified to $55^{\circ} \mathrm{C}$ for $1 \mathrm{~min}$ and extension temperature of $72^{\circ} \mathrm{C}$ for 1 min were used.

To test the possible role of WDS2 in hyperosmotic stress response, wild type, wds1, wds2 and wds1 wds2 mutants were grown on MS plates (control) and MS plates containing $300 \mathrm{mM} \mathrm{D-mannitol}$ (hyperosmotic stress). 10 seeds were sowed in each plate and kept in long day condition for 25 days. Microscopic images of the average seedling size were taken at $11 d, 18 d$ and $25 d$ using a Discovery V12 SteREO microscope (Carl Zeiss). 


\section{Chapter III}

\section{Results}

\subsection{Isolation and molecular characterization of WDS2}

Two different SALK T-DNA insertion lines in the Col-0 wild-type background, both with a T-DNA insertion in the first exon of the gene At5g08560 (WDS2) (Table

3.1) (Figure 3.1), were obtained from Arabidopsis Biological Resource Center (ABRC). T-DNA insertion and homozygous lines were confirmed by using PCRbased markers that can distinguish between the Col-0 wild-type plants, T-DNA hemizygotes, and T-DNA homozygotes. Based on the reported insertion location and flanking genomic sequences, left primers (LP) and right primers (RP) were designed to identify the homozygous mutants. The T-DNA insertions were confirmed by using the left border sequence of the T-DNA (LBa1) and right primer (RP) of each SALK line (http://signal.salk.edu/cgi-bin/tdnaexpress). Of the two SALK lines tested (SALK_095495 and SALK_100917), T-DNA insertion homozygous line was found only in SALK_100917 in the first exon (Figure 3.1) (Figure 3.2).

The T-DNA homozygous mutant of wds1 (SALK_106274) (Xiong, 2007) was confirmed and used as a female to cross with the wds2 mutant (SALK_100917), which was used as a male (pollen donor) (Figure 3.2). The seeds of the first generation (F1) were collected and allowed to self-pollinate in order to identify homozygote mutants, predicted to occur in a $\frac{1}{4}$ wds 1 wds2. The seeds of the 
T-DNA homozygous line of the double crossing was collected and verified in the next generation (Figure 3.2).

SALK lines of wds2 were screened for the absence of mRNA transcript by using semi-quantitative reverse transcription PCR (RT-PCR). Total mRNA was isolated from 16-day old seedling (wds2 and Col-0 wild-type). The control gene ACTIN was equally expressed in the mutant and Col-0 wild-type plants. The transcript of WDS2 was absent in the SALK_100917 after 30 cycles of PCR (Figure 3.3). 
Table 3.1: Members of the Arabidopsis WDS gene family and SALK T-DNA insertion lines.

\begin{tabular}{|c|c|c|c|c|c|c|}
\hline \multirow{2}{*}{$\begin{array}{l}\text { Gene } \\
\text { Locus }\end{array}$} & \multirow{2}{*}{$\begin{array}{l}\text { Description of } \\
\text { Encoded Protein }\end{array}$} & \multirow{2}{*}{$\begin{array}{l}\text { Physical } \\
\text { Map } \\
\text { Position } \\
\text { kbp }\end{array}$} & \multicolumn{3}{|c|}{$\begin{array}{l}\text { Full Sequence Length } \\
\text { (bp) }\end{array}$} & \multirow{2}{*}{$\begin{array}{l}\text { T-DNA } \\
\text { SALK }\end{array}$} \\
\hline & & & CDS & $\begin{array}{l}\text { Genomic } \\
\text { DNA }\end{array}$ & cDNA & \\
\hline $\begin{array}{c}\text { At5g43920 } \\
(\text { WDS1) }\end{array}$ & $\begin{array}{l}\text { Transducin family } \\
\text { protein / WD- } 40 \\
\text { repeat family } \\
\text { protein }\end{array}$ & 17.69 & 1572 & 3177 & 2515 & $\begin{array}{l}\text { SALK_106274.37.55.x (exon) } \\
\text { SALK_022240.33.40.x (300-UTR5) }\end{array}$ \\
\hline $\begin{array}{c}\text { At5g08560 } \\
(\text { WDS2) }\end{array}$ & $\begin{array}{l}\text { Transducin family } \\
\text { protein / WD- } 40 \\
\text { repeat family } \\
\text { protein }\end{array}$ & 2.77 & 1770 & 3799 & 2299 & $\begin{array}{l}\text { SALK_095495.45.95.x (exon) } \\
\text { SALK_100917.52.75.x (exon) }\end{array}$ \\
\hline $\begin{array}{l}\text { At1g73720 } \\
\text { (WDS3) }\end{array}$ & $\begin{array}{l}\text { Transducin family } \\
\text { protein / WD- } 40 \\
\text { repeat family } \\
\text { protein }\end{array}$ & 27.73 & 1536 & 4930 & 1802 & $\begin{array}{l}\text { SALK_123852.55.00.x (exon) } \\
\text { SALK_051163.50.20.x (intron) }\end{array}$ \\
\hline $\begin{array}{l}\text { At5g27570 } \\
\text { (WDS4) }\end{array}$ & $\begin{array}{l}\text { Transducin family } \\
\text { protein / WD- } 40 \\
\text { repeat family } \\
\text { protein }\end{array}$ & 9.73 & 1236 & 1236 & 1236 & $\begin{array}{l}\text { SALK_087779.52.45.x (exon) } \\
\text { SALK_040079.55.50.x (exon) }\end{array}$ \\
\hline $\begin{array}{l}\text { At5g64730 } \\
\text { (WDS5) }\end{array}$ & $\begin{array}{l}\text { Transducin family } \\
\text { protein / WD- } 40 \\
\text { repeat family } \\
\text { protein }\end{array}$ & 25.89 & 900 & 2156 & 1180 & $\begin{array}{l}\text { SALK_126634.23.15.x (exon) } \\
\text { SALK_075672.53.25.x (300-UTR5) }\end{array}$ \\
\hline
\end{tabular}


Figure 3.1: Schematic map of the genomic regions corresponding to WDS2 gene with mutation sites indicated.

The location of the T-DNA insert and genomic regions was mapped using SIGnAL "T-DNA Express" Arabidopsis Gene Mapping Tool (http://signal.salk.edu/cgi-bin/tdnaexpress) and the Arabidopsis Information Resource (TAIR; http://www.arabidopsis.org/). Blue boxes stand for $5^{\prime}$ and $3^{\prime}$ untranslated regions (UTRs); red boxes represent exons and lines between red boxes represent introns. The positions of the T-DNA insertion of both SALK_095495 and SALK_100917 are mapped. The start codon ATG and stop codon TGA are indicated by an arrow. 


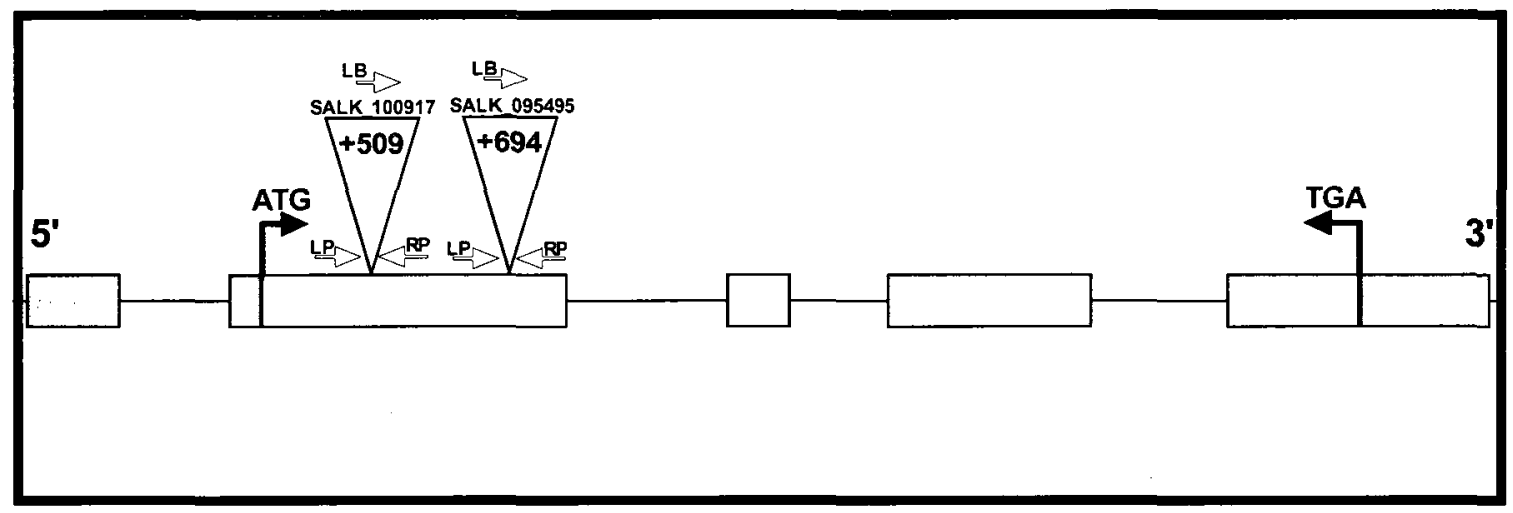


Figure 3.2: PCR amplification for identification of homozygous mutant lines of $w d s 1$, $w d s 2$ and $w d s 1$ wds2 mutants.

Leaves from wild type, single mutant (SALK_106274 for wds1 and SALK_100917 for wds2) and double mutant lines were collected for DNA extraction. PCR amplification with the T-DNA (LBa1) and gene-specific (LP and RP) primers was performed on the corresponding genomic DNA to identify the homozygous line and T-DNA insertion. a) No band was observed in the wds 1 mutant indicating that wds 1 is homozygous when LP and RP primers were used. However, a band was observed in wds1 mutant indicating the T-DNA insertion line was located in wds1 mutant when LBa1 T-DNA primer was used. b) No band was show in the wds2 mutant indicating that wds2 is homozygous when LP and RP primers were used. However, a band was observed in wds2 mutant indicating the presence of the T-DNA insertion when LBa1 primer was used. c) The confirmation of the homozygous line and T-DNA insertion in wds1 wds2 double mutants. 
a) SALK_106374 (wds1)

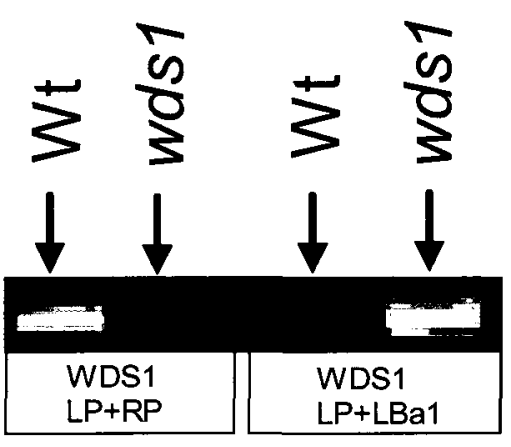

b) SALK_100917 (wds2)

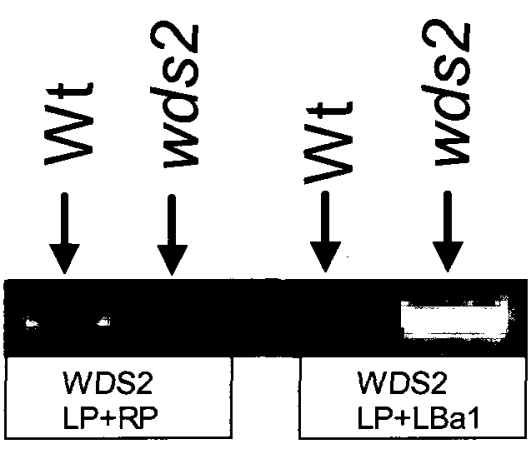

c) wds1 wds2 mutant

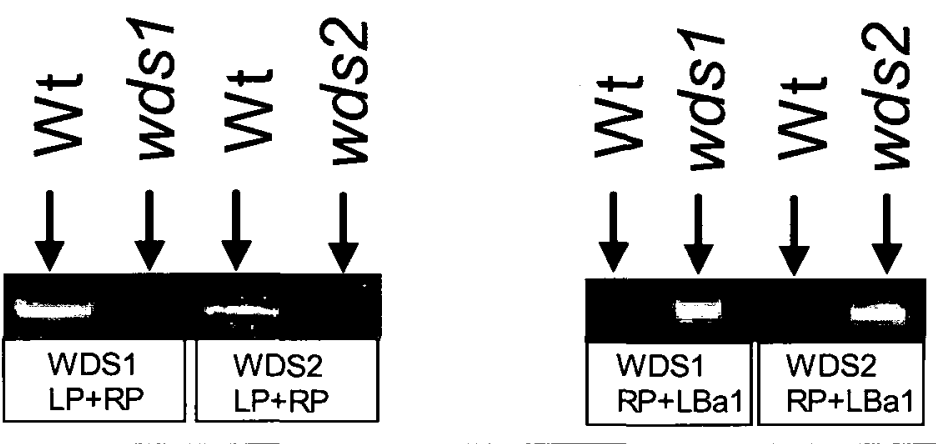


Figure 3.3: Semi-quantitative RT-PCR analysis of mRNA accumulation of WDS2 in Col-0 wild-type and wds2 mutant.

The upper panel shows the WDS2 transcript in Col-0 and wds2 mutant line. The absent band on wds 2 mutant indicates the loss of function. The lower panal shows the expression of the constitutive control gene, ACTIN2. 


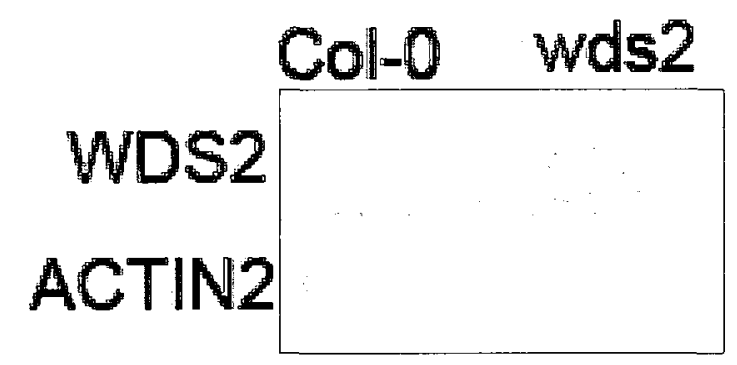




\subsection{Mutant phenotypes of wds1, wds2 and wds1 wds2}

Although the homozygous wds1 mutant grew normally, wds2 and wds1 wds2 double mutants displayed a range of phenotypic abnormalities including early leaf senescence, early flowering, reduced rosette and cauline leaves number and increased silique length (Figure 3.4) (Table 3.2). Plants homozygous for each of the mutant alleles were grown under long day condition (16 h light/ $8 \mathrm{~h}$ dark) and short day condition ( $8 \mathrm{~h}$ light/ $16 \mathrm{~h}$ dark) and compared with Col-0 wild-type plants (Figure 3.4). Both wds2 and wds1 wds2 mutants displayed rapid senescence observed after 32-day-old and 51-day-old in long day and short day condition, respectively. The leaf yellowing proceeded from the top margins toward the bottom of the leaves. First, rapid senescence was observed in cotyledons. Over time, senescence became more evident and spreaded randomly in the other part of rosette leaves. Accelerated leaf senescence and the differences in level of necrosis were also clear in both wds2 and wds1 wds2 double mutants. Whereas cotyledons and rosette leaves of wds1 mutant and wild-type plants were still green, those of $w d s 2$ and the double mutant were yellow and already dry (Figure 3.4-a and-b). Also, we observed a decrease in chlorophyll content in wds2 and wds1 wds2 double mutants of $26 \%$ and $31 \%$, respectively, while Col-0 wild-type and wds1 mutant chlorophyll leached of $6 \%$ (Figure 3.4-c). These results suggest that WDS2 plays a role in the regulation of senescence, but not WDS1. There was no significant phenotypic difference in root elongation between each mutant and Col-0 wild-type plants (Table 3.2). wds2 and wds1 wds2 mutants flowered slightly earlier (28 and 25 days, respectively) than did 
the wds 1 and Col-0 wild-type ( 35 and 36 days, respectively) and with fewer leaves and longer siliques (Table 3.2). 
Figure 3.4: Phenotypic analysis of $w d s 1, w d s 2$ and $w d s 1$ wds2 mutants in long-day and short-day condition.

Col-0 wild type, wds1, wds2, and wds1 wds2 mutants were germinated on MS plates for 11 days in a growth chamber under long day condition (16 h of light, 8 hours of dark) and short day condition (8 hours of light, 16 hours of dark). Small plants were then transferred to pots and grown in the same growth chamber under the same condition. The plants were photographed from day 32 to day 45 in long day condition and at 51 day-old in short day condition. Phenotypes were also recorded on detached leaves. Bar, $2 \mathrm{~cm}$. The chlorophyll content of the plants were also measured in long day condition. Results are based on three replicate experiments where $n=216$ for each.

a) phenotype in long day (LD) condition.

b) phenotype in short day (SD) condition.

c) the change of chlorophyll content of the indicated detached leaves at $32,35,40$ and 45 at the long day condition were recorded. 


\section{a) LD}

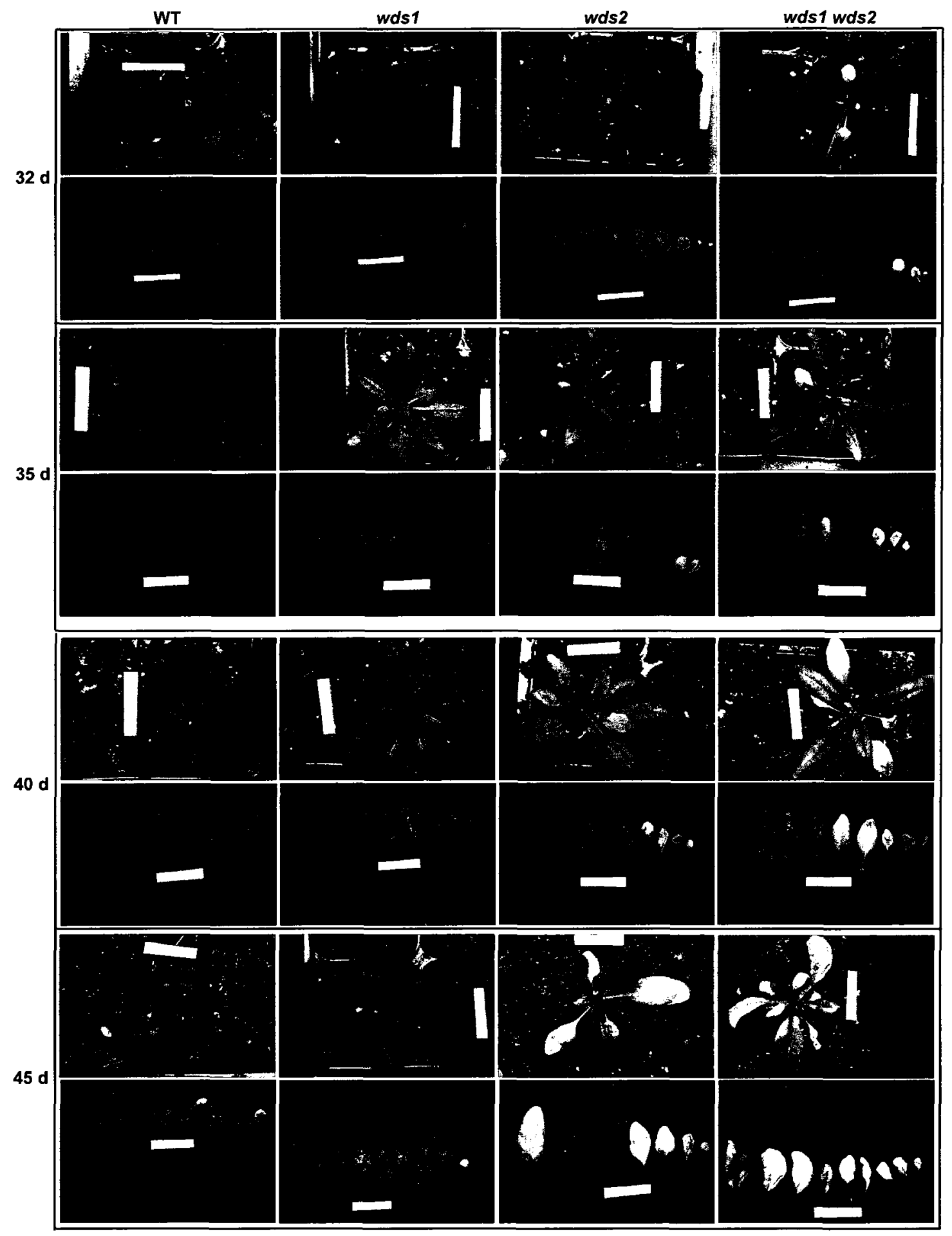


b) SD

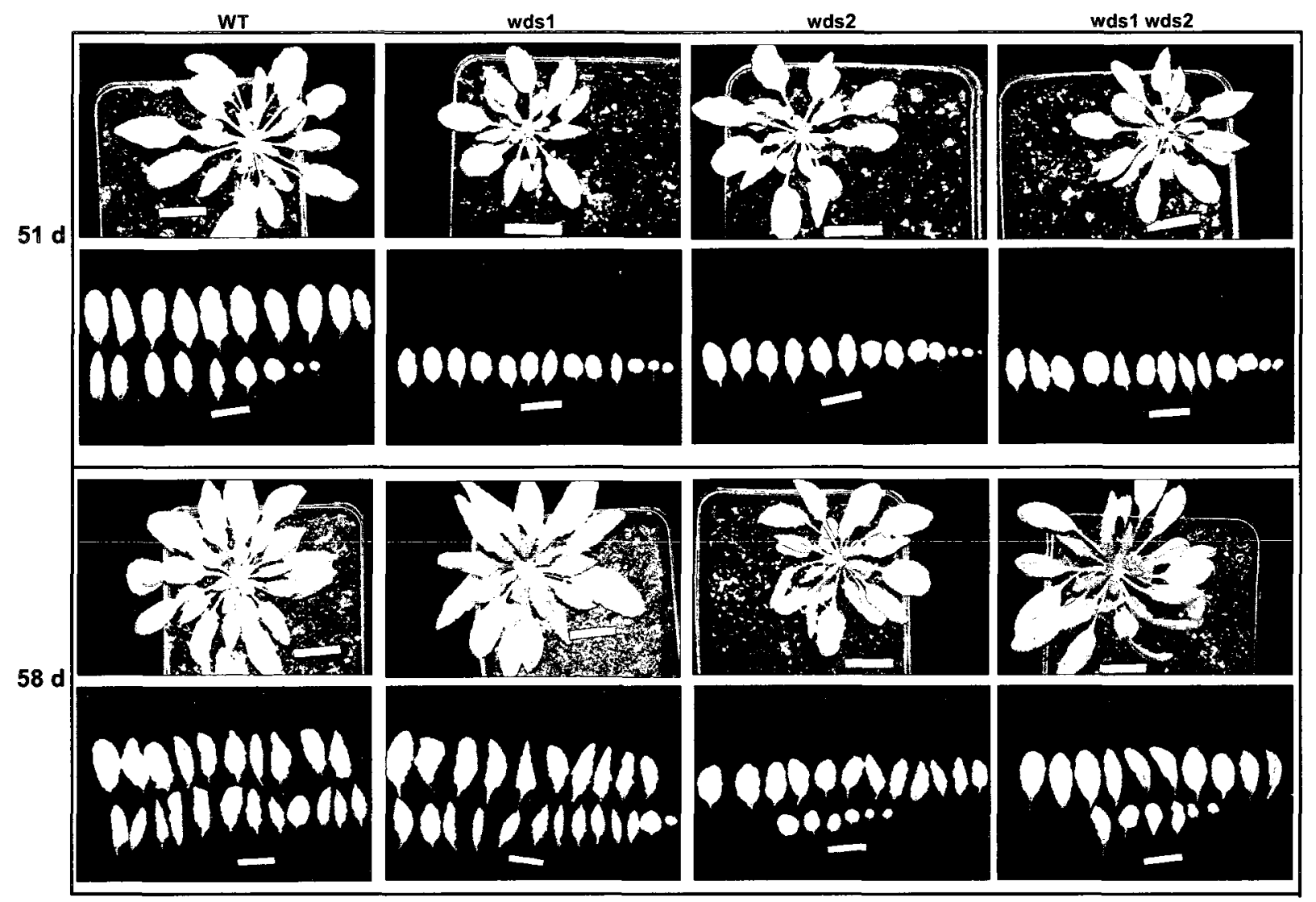


c) The change of chlorophyll content in LD

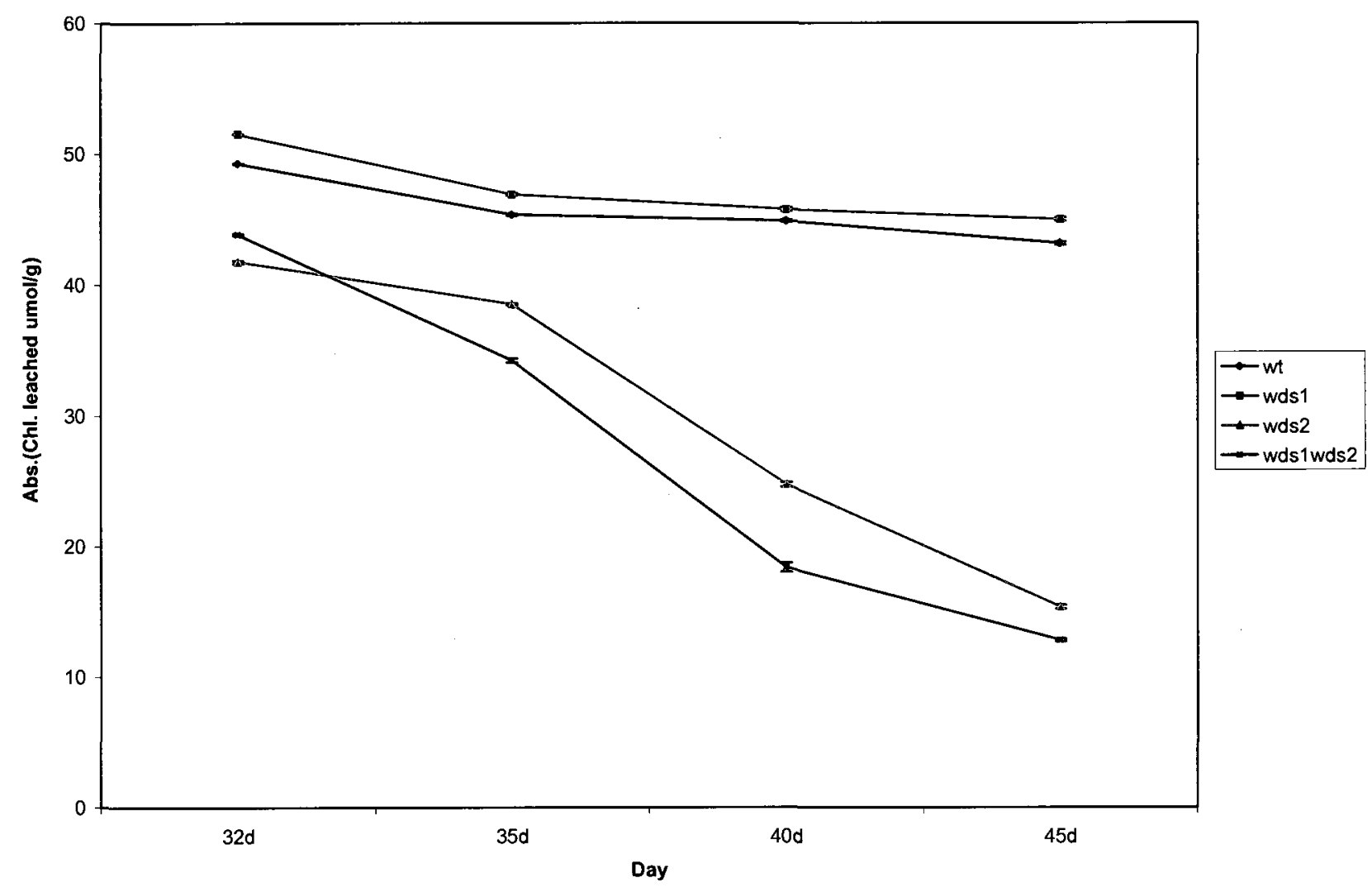


Table 3.2: Flowering time, leaf numbers (35-day-old), silique size $(\mathrm{mm})$ ( 49-day-old) and root length $(\mathrm{cm})(9$-day-old) of wds1 and wds2 mutants.

\begin{tabular}{|c|c|c|c|c|c|}
\hline Plants & $\begin{array}{c}\text { Rosette leaf } \\
\text { number }^{a, c}\end{array}$ & $\begin{array}{c}\text { Cauline leaf } \\
\text { number }^{a, c}\end{array}$ & $\begin{array}{c}\text { Silique } \\
\text { length }^{a, c} \\
(\mathbf{m m})\end{array}$ & $\begin{array}{c}\text { Root } \\
\text { length } \\
(\mathbf{c m})\end{array}$ & $\begin{array}{c}\text { Flowering } \\
\text { time }^{a, c} \\
\pm 1 \text { day }\end{array}$ \\
\hline Col-0 & $13.90 \pm 0.30$ & $3.24 \pm 0.43$ & $13.86 \pm 0.36$ & $3.25 \pm 0.63$ & 35 -day-old \pm 1 \\
\hline wds1 & $13.61 \pm 0.58$ & $3.14 \pm 0.36$ & $13.67 \pm 0.58$ & $3.13 \pm 0.64$ & 36 -day-old \pm 1 \\
\hline wds2 & $11.19 \pm 1.24$ & $2.76 \pm 0.43$ & $17.76 \pm 1.26$ & $3.03 \pm 0.88$ & 28-day-old \pm 1 \\
\hline wds1 wds2 & $10.80 \pm 1.07$ & $2.28 \pm 0.56$ & $16.71 \pm 1.23$ & $3.12 \pm 0.77$ & 25-day-old \pm 1 \\
\hline
\end{tabular}

${ }^{a}$ : Data based on three repeats of experiments

${ }^{b}$ : Data based on four repeats of experiments

$c$ : Standard deviation

\subsection{Response of WDS2 to hyperosmotic stress}

The effect of $300 \mathrm{mM}$ mannitol during seedling development of wds1, wds2, wds1 wds2, and Col-0 wild type plants was examined to determine the role of WDS genes in response to osmotic stress. Sterilized seeds of all the indicated genotypes of plants were germinated on MS plates or MS plates containing $300 \mathrm{mM}$ mannitol for 25 days in a growth chamber under long day conditions ( $16 \mathrm{~h}$ light/ $8 \mathrm{~h}$ dark). After that, seedlings were photographed at 11,18 and 25 days using a Carl Zeiss Discovery V12 SteREO microscope. As shown in Figure 3.5, there was similar growth inhibition on all mutants and control seedlings grown with $300 \mathrm{mM}$ mannitol at 11 and 18-day-old. However, at 25-day-old, seedling death was much more significant in wds2 and double mutants. The wds1 mutant plants showed no 
significant difference in size comparing to the other mutants. The mutants and control plant were shrunken due to osmotic stress at each time points. The results show that the WDS2 may play an important role in response to osmotic stress. 
Figure 3.5: The effect of hyperosmotic stress on wild type, wds1, wds2, and wds1 wds2 in tissue culture.

Col-0 wild-type, wds1, wds2, and wds1 wds2 plants were grown in standard MS medium or MS containing $300 \mathrm{mM}$ mannitol for 25 days in a growth chamber under long day conditions ( $16 \mathrm{~h}$ light/ $8 \mathrm{~h}$ dark). Then, microscopic photographs were taken using a Carl Zeiss Discovery V12 SteREO microscope at 11, 18 and 25-day-old. Results are based on three replicate experiments where $n=50$ for each. 


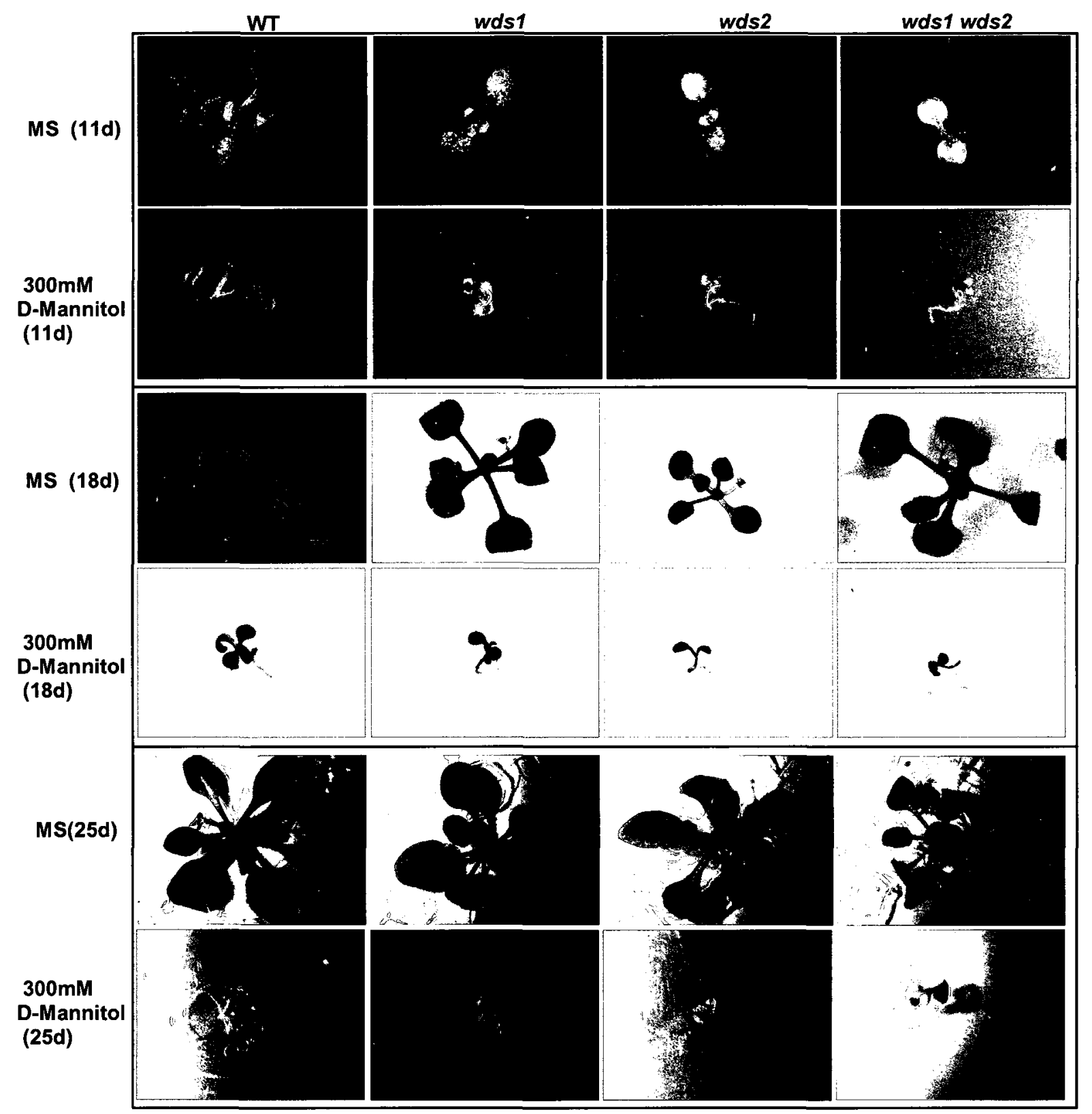




\subsection{Response of WDS2 gene to abiotic stress treatment}

To investigate the expression pattern of WDS1 and WDS2 genes in response to Osmotic stress, RT-PCR was conducted using total RNA isolated from 16-day-old Arabidopsis wild type seedlings that were subjected to $0.6 \mathrm{M} \mathrm{D}$-mannitol treatment. After D-mannitol treatment, the expression of WDS2 was induced after $12 \mathrm{~h}$ and 24 h. However, there was no change in the gene expression of WDS1. This result suggests that the expression of WDS2 gene can be modulated by abiotic stresses and may be involved in the plant response to hyperosmotic stresses. In addition, the expression of the $A D H$ gene is affected by other environmental conditions, such as osmotic stresses, in several plant species as expected (Dolferus et al., 1994; Xie and $\mathrm{Wu}, 1989)$. Therefore, we used it as a marker gene in this work and observed increase in $\mathrm{ADH}$ expression $24 \mathrm{~h}$ after treatment (Figure 3.6). 
Figure 3.6: RT-PCR analysis of WDS2 expression in wild-type seedlings with $0.6 \mathrm{M}$ D-mannitol treatment.

Total RNAs were isolated from 16-day-old of wild type seedlings as outlined in Materials and Methods. The $A D H$ was used as marker gene and ACTIN2 was used as constitutive expression control. Results are based on four replicate experiments. 


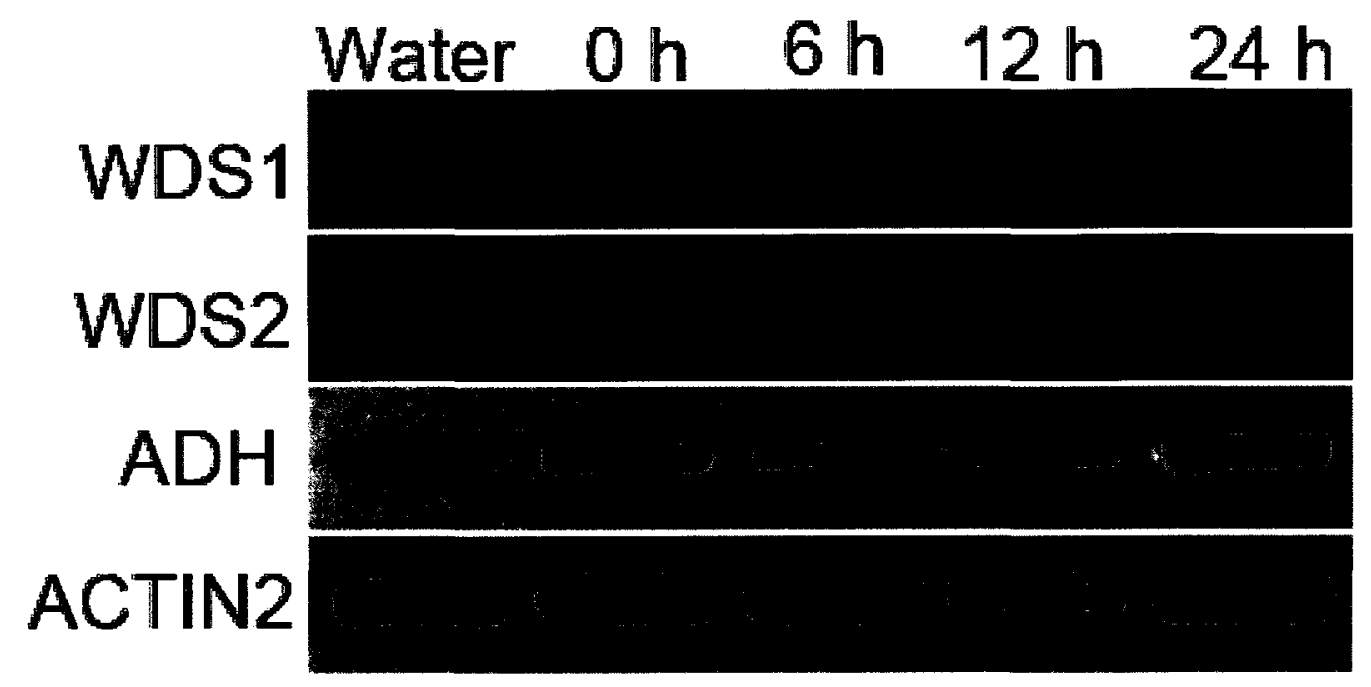




\subsection{Up-regulation of WDS1 and WDS2 transcripts by SA}

To investigate the expression pattern of WDS1 and WDS2 genes in response to salicylic acid, RT-PCR was conducted using total RNA isolated from leaves of threeto-four-week-old Arabidopsis wild type that were subjected to $0.5 \mathrm{mM} \mathrm{SA}$ treatment. After SA treatment, the expression of WDS1 was increased after 48 hours, and the expression of WDS2 was induced after 24 hours (Figure 3.7). This result suggests that the expression of WDS1 and WDS2 genes downstream of SA pathway. In addition, the expression of the PR1 gene (AT2G14610) is affected by SA as expected (Wang et al., 2007). Therefore, we used it as a marker gene in this work. 
Figure 3.7: RT-PCR analysis of WDS1 and WDS2 expression in wild-type Arabidopsis leaves with $0.5 \mathrm{mM}$ SA treatment.

Total RNAs were isolated from three-to-four-week-old Arabidopsis wild type as outlined in Materials and Methods. PR1 was used as marker gene and ACTIN2 was used as constitutive expression control. Results are based on three replicate experiments. 


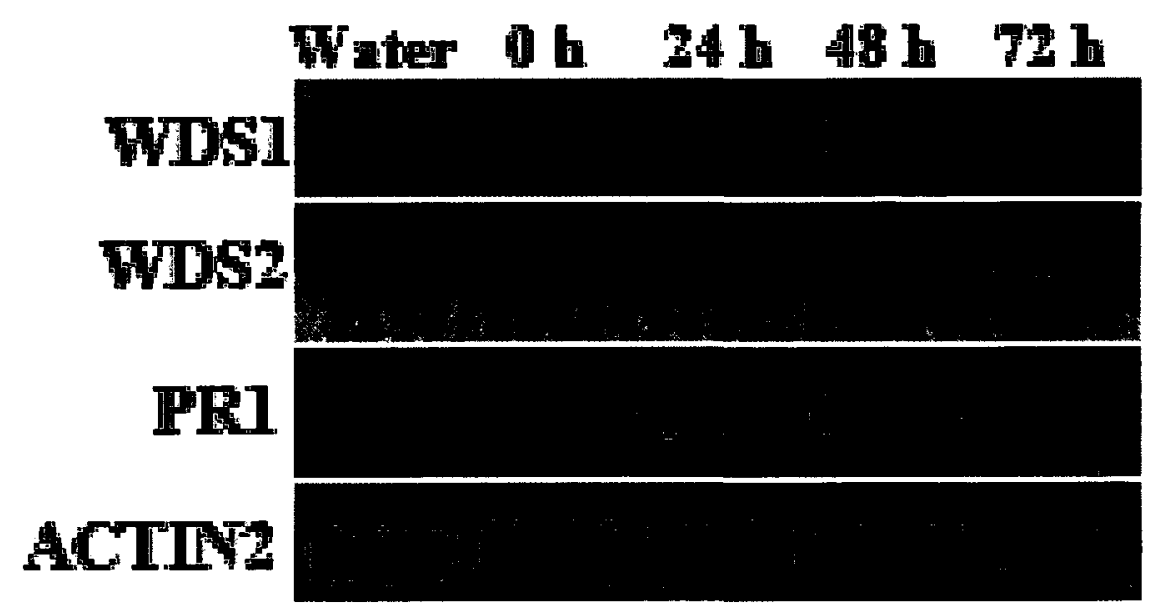




\subsection{Leaf senescence induced by senescence-accelerating hormones such as}

salicylic acid (SA) is accelerated in wds2

Our gene expression data in section 3.5 revealed that WDS1 and WDS2 are induced by SA. Thus, we examined the response of the mutants as well as the Col-0 wild-type plants to the senescence-accelerating hormone SA (Figure 3.8). When leaves detached from four-week-old Col-0, wds1, wds2, and wds1 wds2 mutant plants were treated with two different concentration of $\mathrm{SA}(0.5 \mathrm{mM}$ and $2.0 \mathrm{mM})$, we observed a decrease in chlorophyll content in all mutant lines. However, at $0.5 \mathrm{mM}$ and $2.0 \mathrm{mM} \mathrm{SA}$, after 96 hours of incubation, the chlorophyll contents in wds2 and double mutants were less than $12 \%$, in contrast to Col-0 wild type and wds 1 which retained $18 \%$ and $23 \%$ of its chlorophyll (Figure 3.8-b and c). The chlorophyll level at $\mathrm{O} \mathrm{h}$ of all plants was subtracted from the level at $96 \mathrm{~h}$ incubation time in order to determine how much chlorophyll was leached in each mutant line and Col-0 wild type plants. The differences were recorded and plotted in Figure 3.8-d. This indicated that more chlorophyll was leached in wds2 and double mutants than in Col-0 wild-type and wds1 mutant when treated with SA (Figure 3.8-d). 
Figure 3.8: The change of chlorophyll content in response to SA treatment. The change of chlorophyll content in detached leaves was recorded at $0,24,48,72$ and 96 hours after treatment with $0.5 \mathrm{mM}, 2.0 \mathrm{mM} \mathrm{SA}$ or water (as control). Results are based on three replicate experiments.

a) Water treatment in Col-0 wild-type and wds1, Col-0 and wds2, and Col-0 and double mutants.

b) $0.5 \mathrm{mM} \mathrm{SA}$ treatment in Col-0 and $w d s 1$, Col-0 and $w d s 2$, and Col-0 and double mutants.

c) $2.0 \mathrm{mM} \mathrm{SA}$ treatment in Col-0 and $w d s 1, \mathrm{Col}-0$ and $w d s 2$, and Col-0 and double mutants.

d) Re-plotting to show the difference of chlorophyll leaching from $0 \mathrm{~h}$ to $96 \mathrm{~h}$ in all lines. 


\section{a) Water}
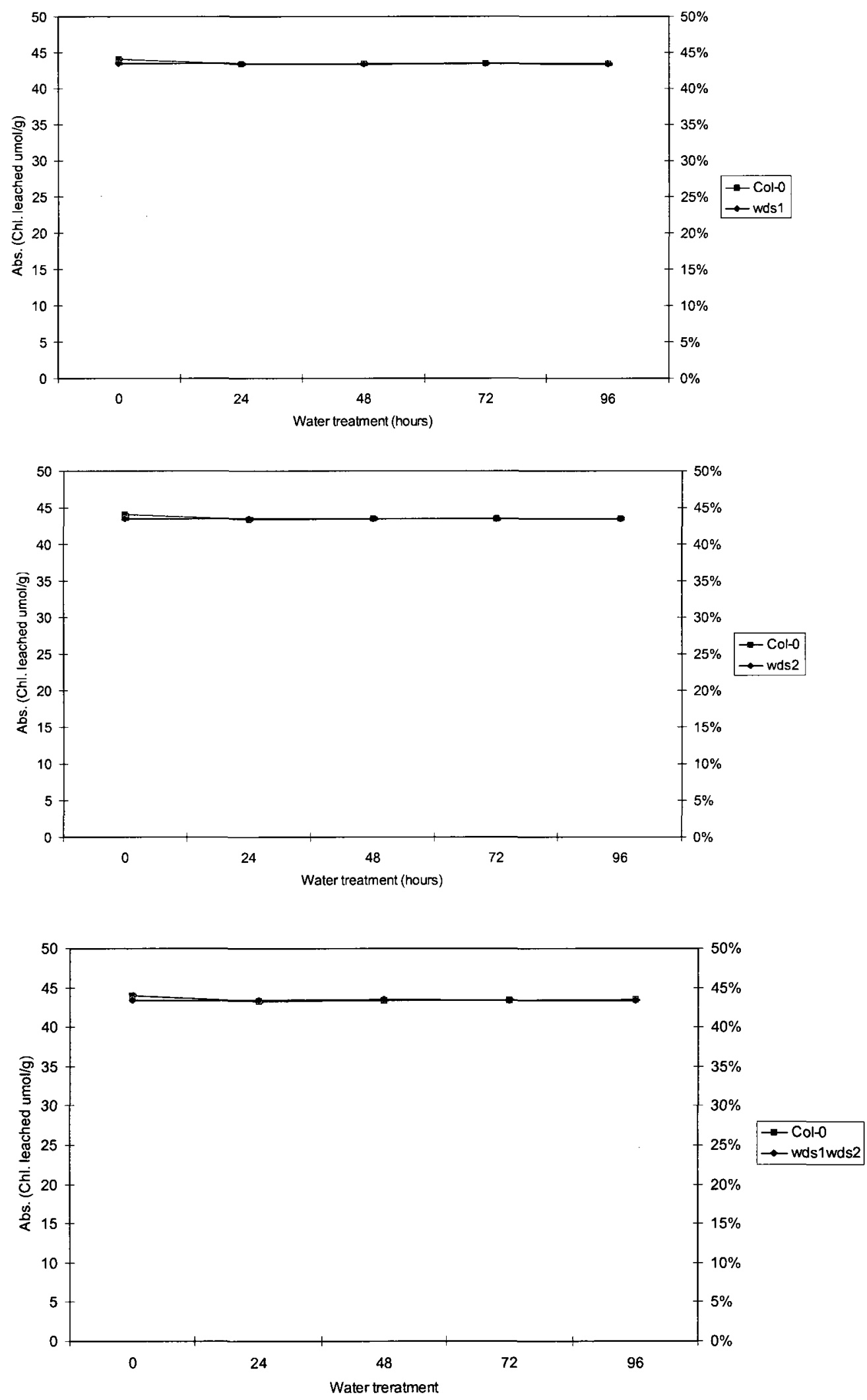
b)

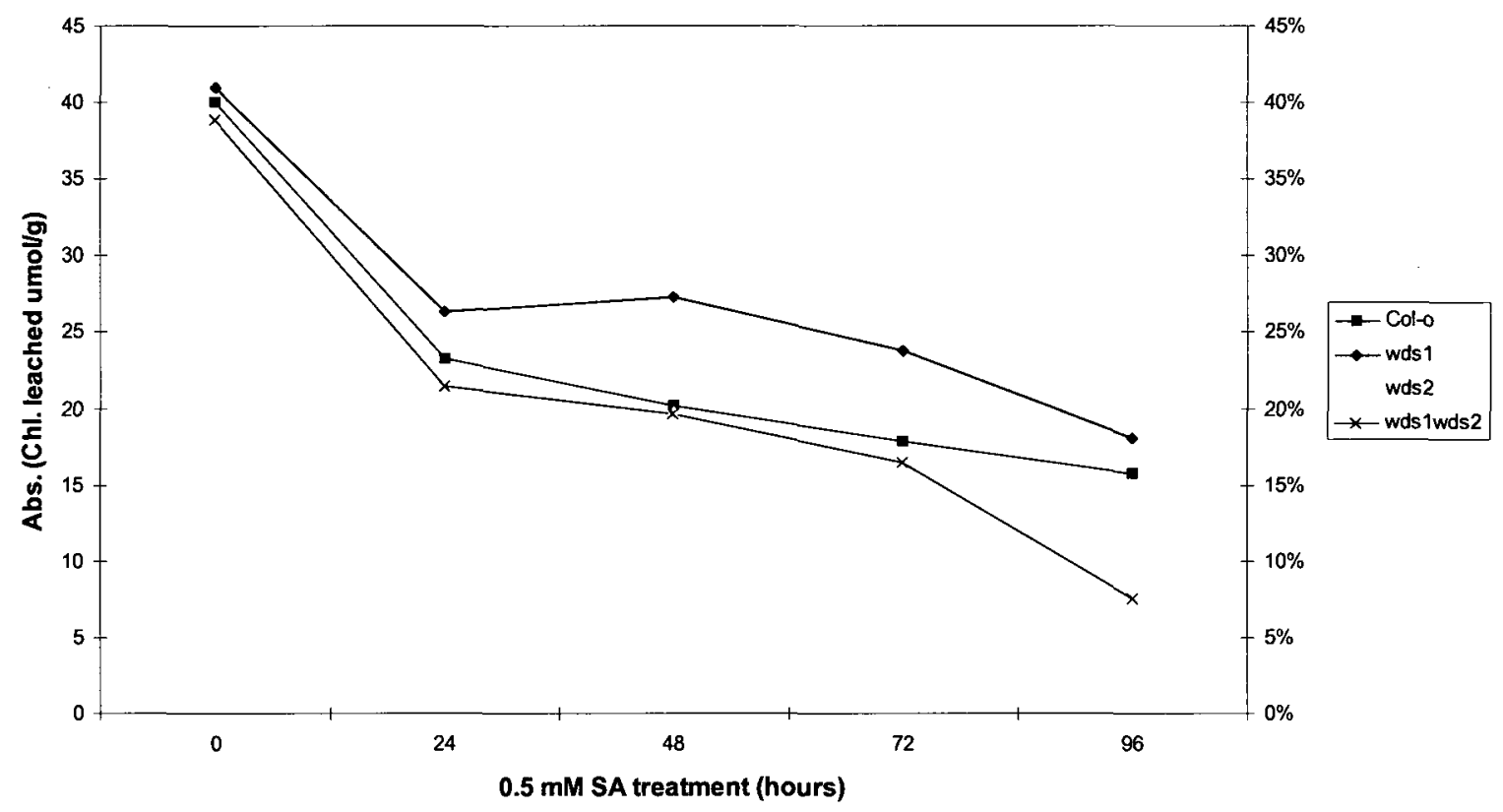

c)

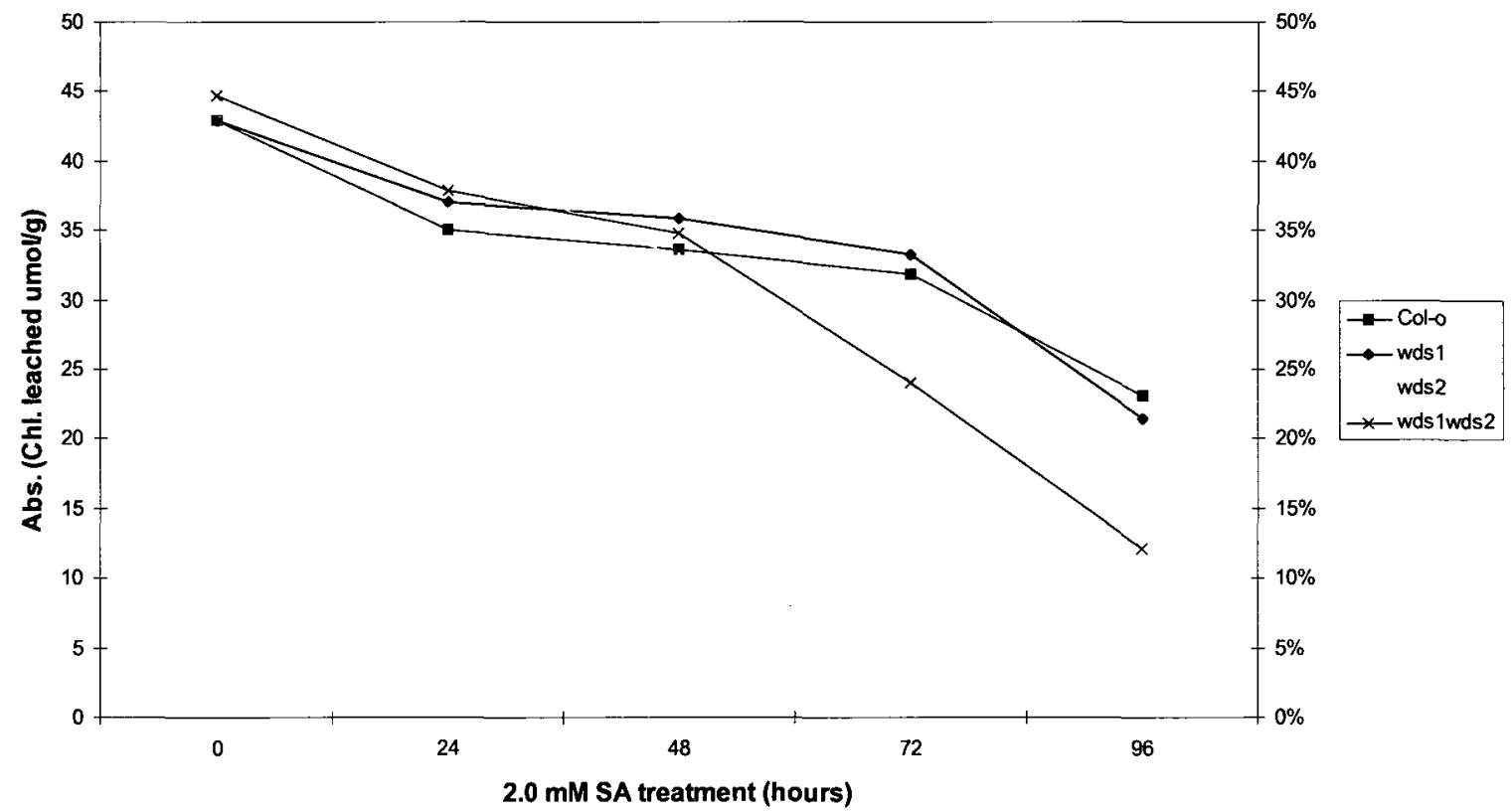


d) Difference in chlorophyll leaching

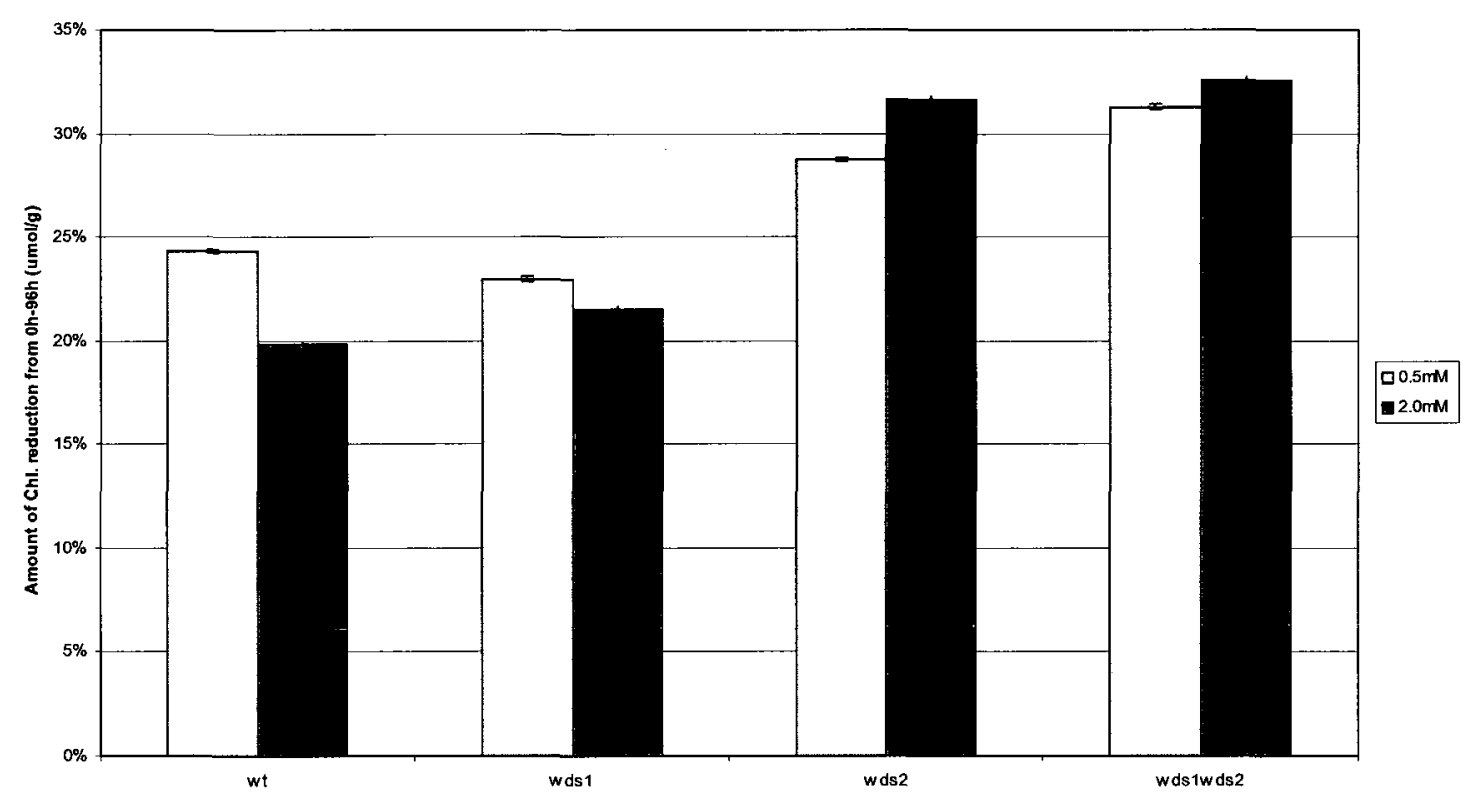




\subsection{Fumonisin B1 induces spontaneous cell death in wds1, wds2 and wds1}

wds2 mutants

Cell death occurred on leaves detached from three-week-old Col-0 wild-type, wds1, wds2 and wds1 wds2 mutant plants when they were treated with different concentrations of FB1 $(1 \mu \mathrm{M}, 2 \mu \mathrm{M}$ and $5 \mu \mathrm{M})$ and incubated in long day conditions for up to $120 \mathrm{~h}$. Trypan blue is an important stain used to selectively color dead tissues or cells blue. Dead cells form dark spots when stained with trypan blue and they can be distinguished from the surrounding, living green cells by using a microscope with white light (Axioplan 2, Carl Zeiss). The cell death was constrained in a limited area and did not visibly accelerate the death of the whole leaf. Leaves were collected from each treatment at $0,24,48,72,96$, and 120h. The dark speckles were scattered on the adaxial surface of leaves, but hardly visible to the naked eye, and did not have defined margins. Water treatment was used as a control for all plants (Figure 3.9-a). When all mutants and Col-0 wild-type plants were treated with $1 \mu \mathrm{M}$ FB1, the earliest cell death in the double mutant was observed at $72 \mathrm{~h}$ (Figure 3.9-b). Then, cell death occurred on wds2 mutant and wds1 wds2 at $120 \mathrm{~h}$. There was no effect on wds1 mutant and Col-0 wild-type (Figure 3.9-b). However, when we increased the concentration of FB1 to $2 \mu \mathrm{M}$ and 5 $\mu \mathrm{M}$, cell death was observed on all mutants. Cell death occurred earlier in the double mutant than on wds 2 mutant. Cell death was then observed on wds1 and Col-0 wildtype plant, respectively (Figure $10 \mathrm{c}, \mathrm{d}$, and e). The dark spots appeared in all plants when we increased the concentration of FB1 and incubated for longer time. 
To determine whether the cell death in the dark spots indicated using the trypan blue assay is associated with callose deposition, we determined the presence of callose with aniline blue in Col-0, wds1, wds2 and wds1 wds2 leaves at $0 \mathrm{~h}, 72 \mathrm{~h}$, $96 \mathrm{~h}$, and $120 \mathrm{~h}$. The accumulation of callose deposition around the site of infection is usually part of the complex cell wall-strengthening process that halts pathogen invasion (Stanghellini and Aragati, 1966). The stain of aniline blue is used to detect callose deposition and produces UV-stimulated fluorescence (Eschrich and Currier, 1964). The fluorescence produced by callose appears as a bright blue fluorescent ring along the cell wall and is distinct from the white autofluorescence under the epifluorescence microscope (Figure 3.10). Cell death was induced more in the double mutant, and wds 2 than on wds1 mutant after $72 \mathrm{~h}$. 
Figure 3.9: Microscopic image of whole-mounted Col-0, wds1, wds2, wds1 wds2 leaves.

All plants of the indicated genotypes were germinated on MS plates for 11 days in a growth chamber under long day conditions (16 h light/ $8 \mathrm{~h}$ dark). Small plants were then transferred to pots and grown in the same growth chamber under the same condition. Leaves detached from three-week-old plants were treated with $1 \mu \mathrm{M}, 2$ $\mu \mathrm{M}, 5 \mu \mathrm{M}$ FB1 and water. It was then stained with trypan blue and mounted in $70 \%$ Glycerol. A microscopic image was taken with white light by Axioplan 2 microscope (Carl Zeiss).

a) Col-0, wds1, wds2, wds1 wds2 leaves under the control (water) treatment. Scale bar, $10 \mu \mathrm{m}$

b) Col-0, wds1, wds2, wds1 wds2 leaves when treated with $1 \mu \mathrm{M}$ FB1. Scale bar, $10 \mu \mathrm{m}$

c) Col-0, wds1, wds2, wds1 wds2 leaves when treated with $2 \mu \mathrm{M}$ FB1. Scale bar, $10 \mu \mathrm{m}$

d) Col-0, wds1, wds2, wds1 wds2 leaves when treated with $5 \mu \mathrm{M}$ FB1. Scale bar, $10 \mu \mathrm{m}$

e) Macroscopic image of $5 \mu \mathrm{M}$ FB1 and water treatments in wds1, wds2, double mutants and Col-0 wild-type leaves. Scale bar, $2 \mathrm{~cm}$. 
a) Water

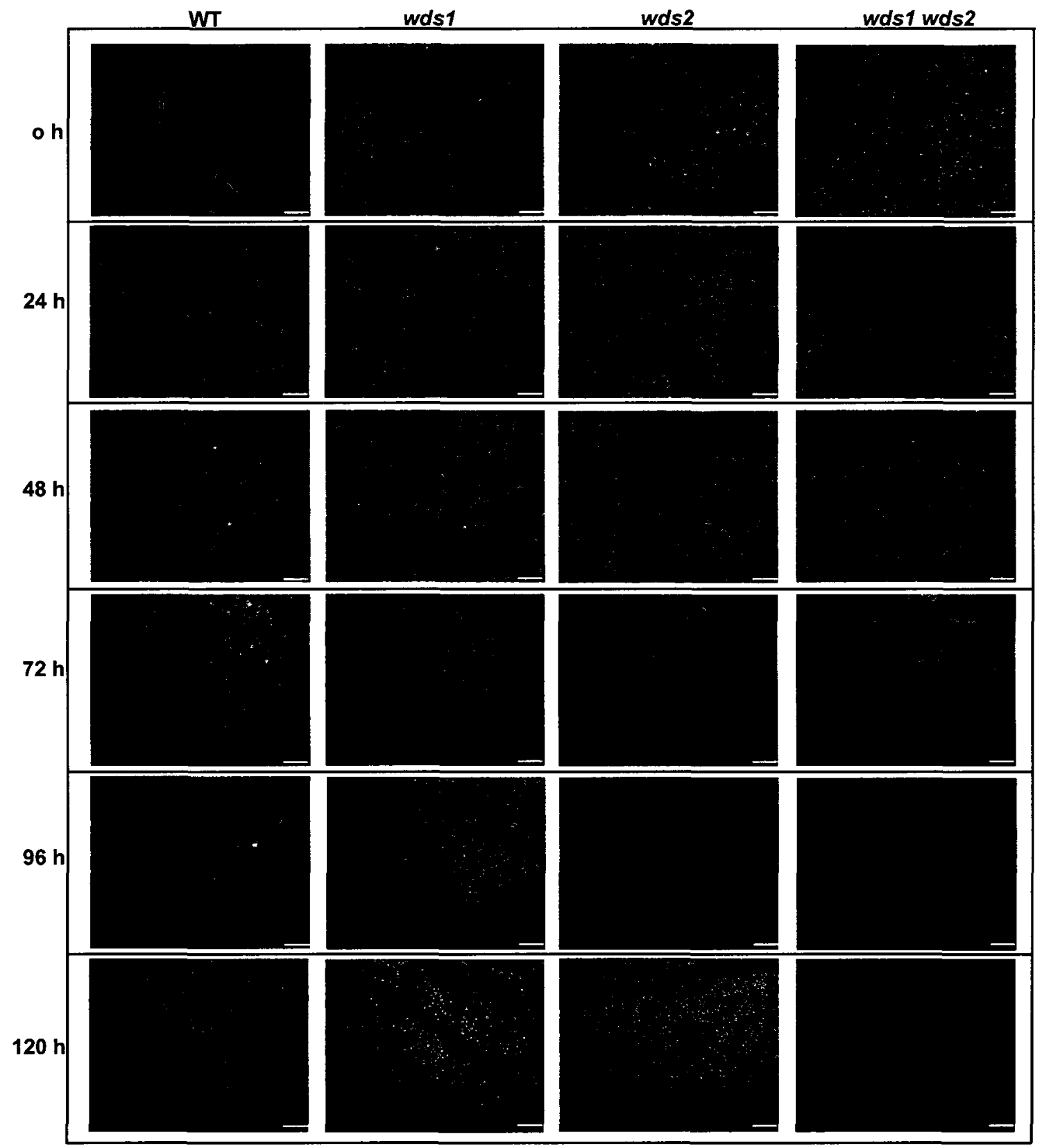


b) $1 \mu \mathrm{M}$ FB1

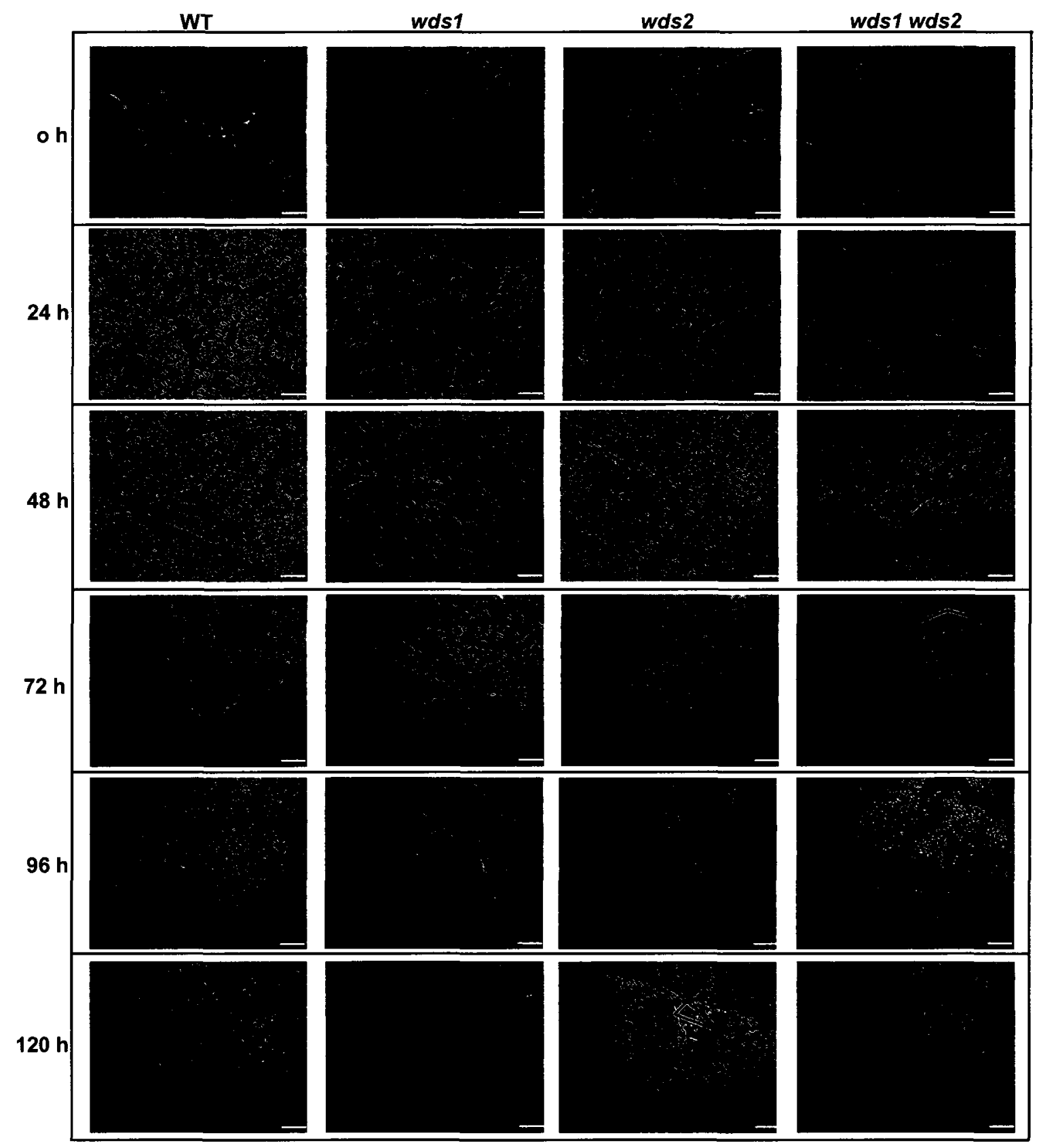


c) $2 \mu \mathrm{M}$ FB1

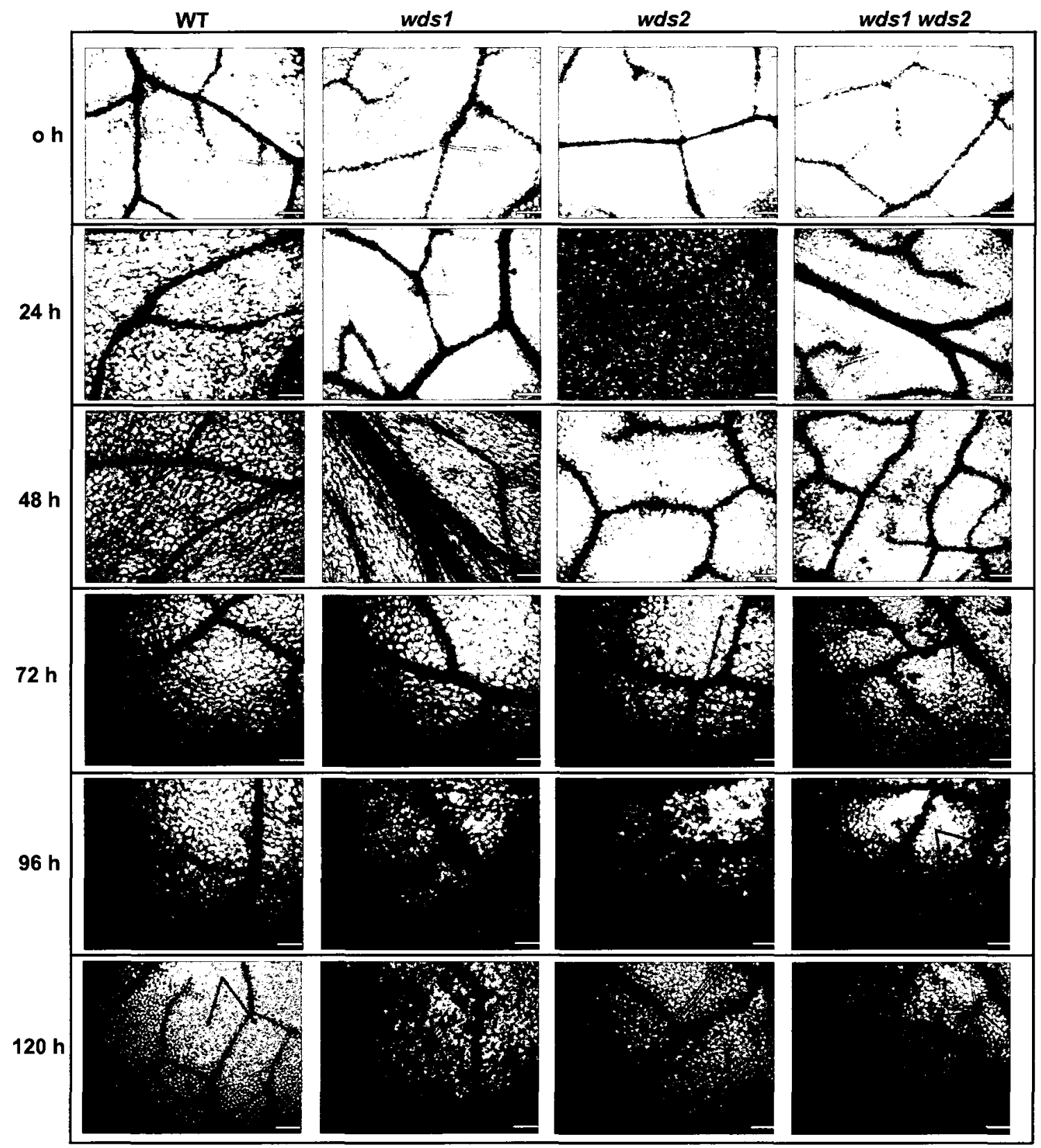


d) $5 \mu \mathrm{M}$ FB1

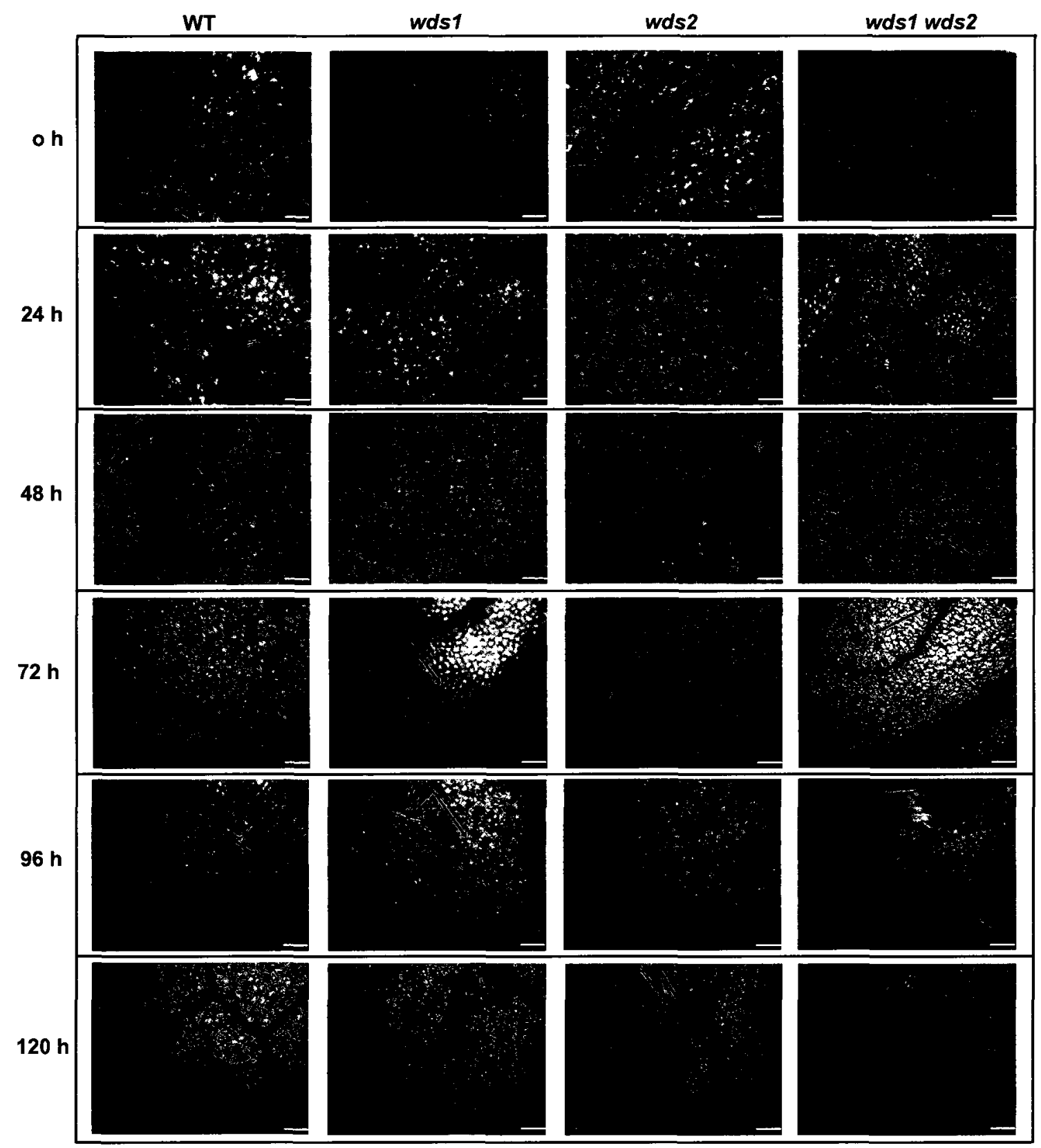


e) Water and $5 \mu M$ FB1
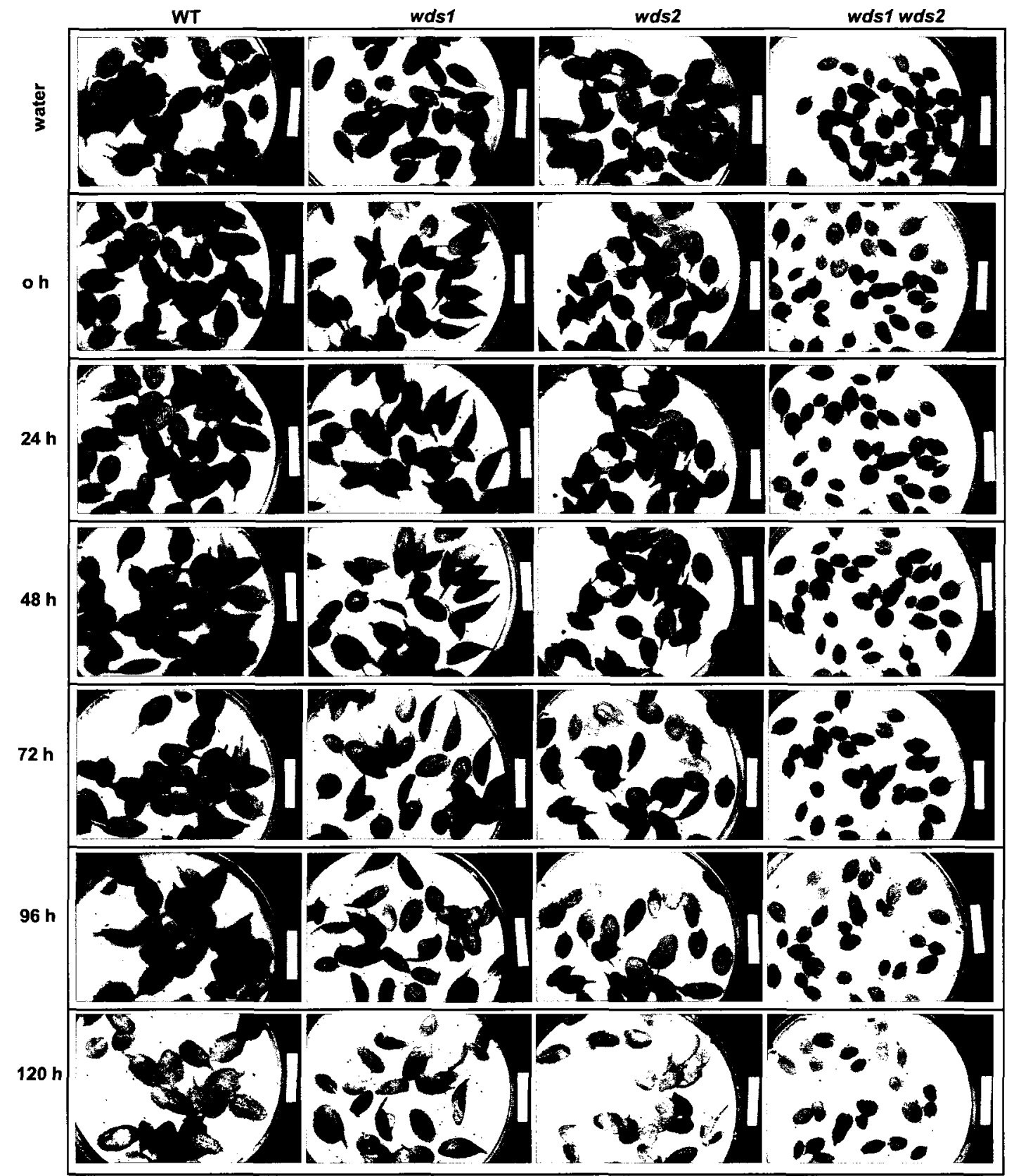
Figure 3.10: Microscopic image of callose deposition in Col-0, wds1, wds2, wds1 $w d s 2$ leaves after $5 \mu \mathrm{M}$ FB1 treatment.

All plants were germinated on MS plates for 11 days in a growth chamber under long day conditions ( $16 \mathrm{~h}$ light/ $8 \mathrm{~h}$ dark). Small plants were then transferred to pots and grown in the same growth chamber under the same condition. Leaves detached from three-week-old plants were treated with water and $5 \mu \mathrm{M}$ FB1 and stained with aniline blue. The whole leaves were mounted in $70 \%$ glycerol. A microscopic image was taken using a microscope equipped with a UV light source and DAPI filter (scan range: $320-520 \mathrm{~nm}$ ) (Axioplan 2, Carl Zeiss). Scale bar, 10 $\mu \mathrm{m}$. 


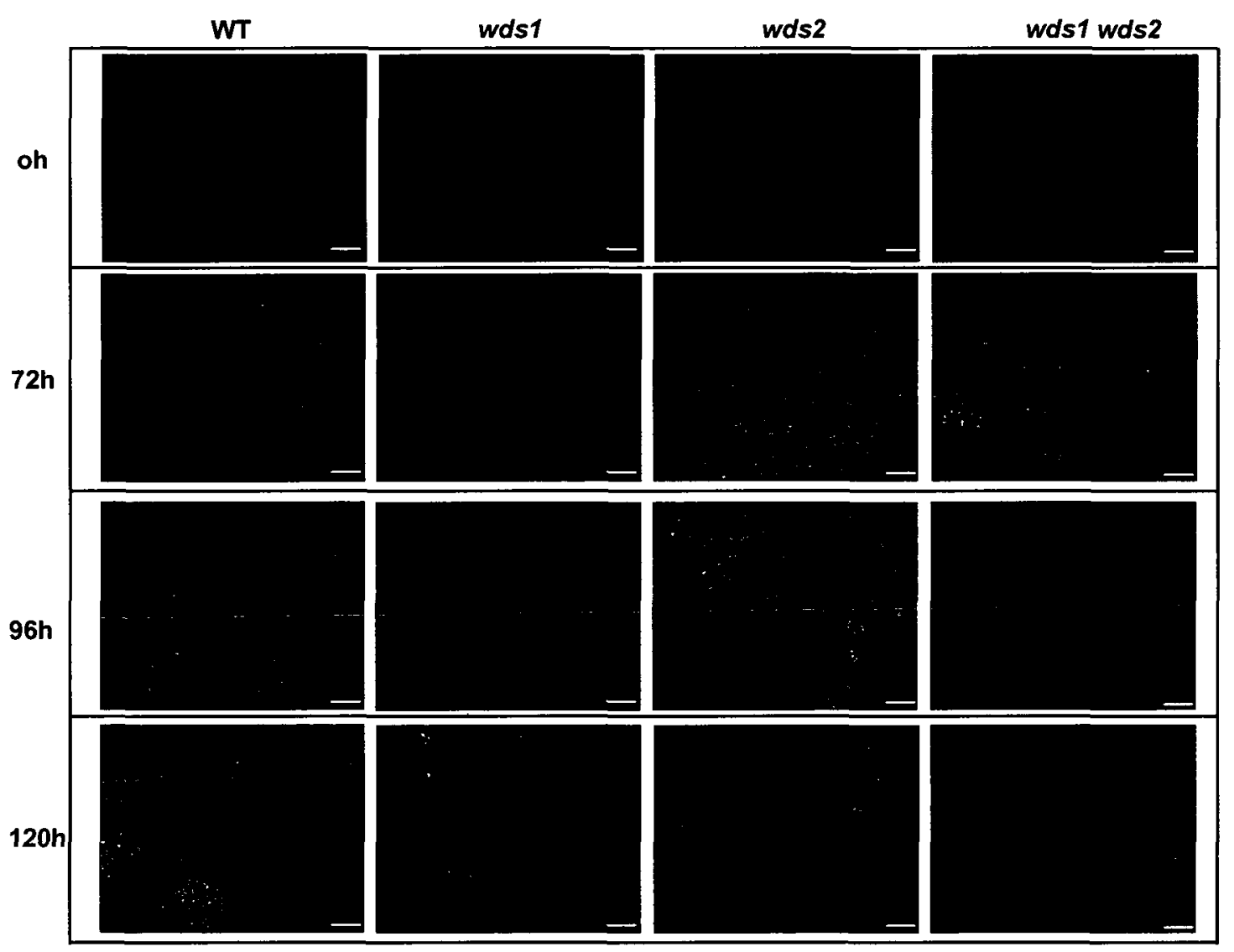




\subsection{Subcellular localization of WDS2}

Heazlewood et al. (2007) are using various data sources together to build SUBA, a SUBcellular location database for Arabidopsis proteins. This provides subcellular prediction information for proteins based on amino acid sequence using 6743 nonredundant proteins and characterizes the proteins encoded in the transcripts responsible for $51 \%$ of Arabidopsis expressed sequence tags (Heazlewood et al., 2007). Based on Heazlewood et al. (2007), I predicted that WDS2 is probably located in the nucleus. To examine the subcellular localization of WDS2, a green florescent protein (GFP)-WDS2 fusion protein was transiently expressed in 5-weekold tobacco leaves. The GFP-WDS2 fusion appeared to be located in the nuclei of cells in the tobacco leaf (Figure 3.11). DAPI, blue fluorescent stain was used to label nuclei (Figure 3.11-d). Also, water infiltration was used as a control, only revealed autofluorescence in chloroplast (Figure 3.11-e and -f). 
Figure 3.11: Nuclear localization of GFP-WDS2 in DAPI blue-treated transgenic tobacco plants.

(A) Diagram of WDS2 constructs in the pVKH18::GFPN vector. GFP, green fluorescent protein and $35 \mathrm{~S}$ promoter is located in pVKH18 vector. (B) Nuclear localization of GFP-WDS2. The full length WDS2 gene was fused to the coding sequence of GFP located in pVKH18 and the binary construct introduced into tobacco plants by Agrobacterium mediated transient delivery. After 4 days of incubation, localization of WDS2-GFPN was examined by confocal microscopy. Nuclear speckle was detected in the WDS2 under the following conditions: (a) fluorescence image of cell putatively expressing GFP-WDS2 (505-650 nm); (b) autofluorescence image of panel a (>650 nm); (c) bright field image of panel a; (d) DAPI staining of panel a; (e) control (water) injection showing autofluorescence from

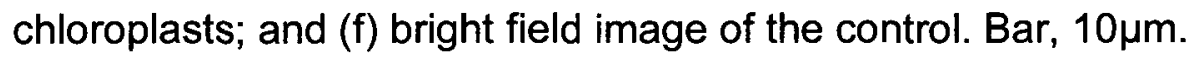


A)

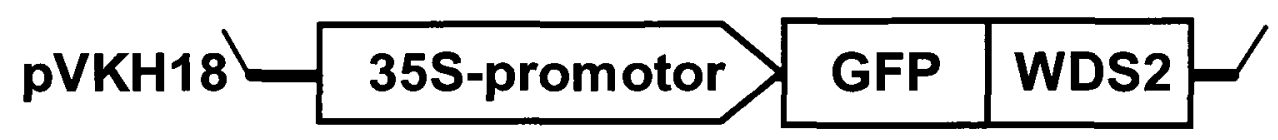
T-DNA

B)

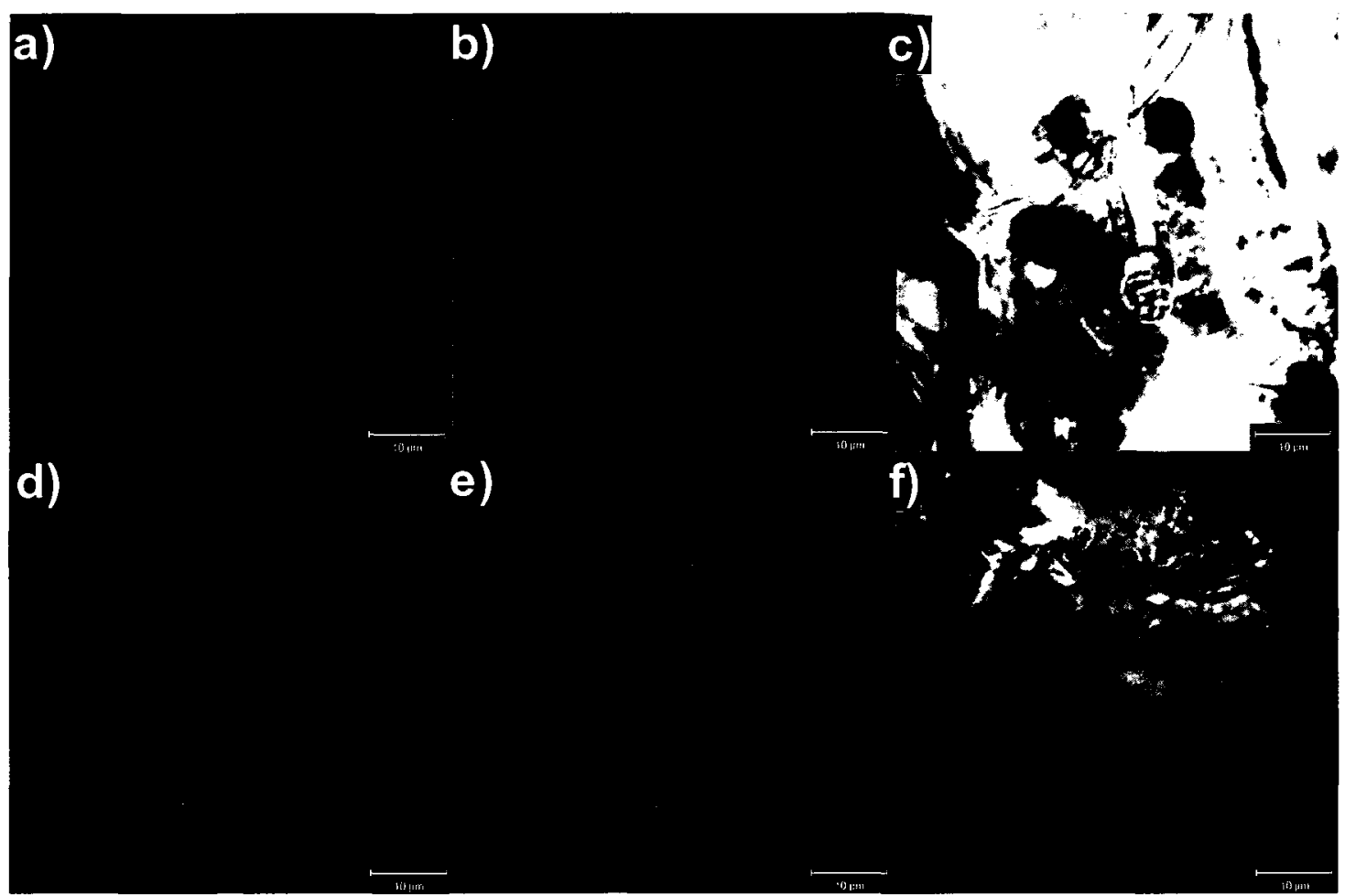




\section{Chapter IV}

\section{Discussion, Conclusion and Future Research}

\section{Discussion:}

Programmed cell death is a physiological process that involves the selective elimination of unwanted cells. It plays an important role in cell and tissue homeostasis, cellular differentiation, tissue sculpting, and disease resistance. Senescence, as a visible form of cell death, is a complex process and represents a highly regulated developmental stage (Hammond-kosack \& Jones, 1996; Kim et al., 2008). Senescence results in chlorophyll breakdown, RNA and protein degradation, and translocation of nitrogen, carbon nutrients, and minerals from the senescing leaves to other parts of the plants, and eventually leads to cell death (Lim and Nam, 2005). The application of physiological and molecular biological methods to study leaf senescence has enabled the isolation and characterization of a large range of senescence associated genes ( $S A G s$ ) that have increased gene expression in senescing leaves. Studies of these genes and identification of the functions of the encoded proteins have given further insights into the complex processes that take place during senescence. The combined action of several biotic and abiotic factors may be involved in the induction of senescence (Lim and Nam, 2005). The initiation of leaf senescence can be induced by many different internal and external factors. Environmental factors such as temperature, wounding, nutrient supply and pathogen attack may all result in the initiation of leaf senescence (Bleecker and Patterson, 1997). However, today, scientists struggle to answer many questions regarding the 
process of leaf senescence and cell death, such as how and when leaf senescence is initiated, what is the threshold that triggers leaf senescence and cell death, and how the developmental age is recognized.

Today, bioinformatics allows scientists to study genome-wide gene expression patterns in a single experiment, relatively quickly and efficiently. Thus, with the aid of bioinformatics, we can start to analyze functions and functional correlations of multiple genes on a genome scale, such as in the case of genes that are specifically up-regulated during leaf senescence (e.g. SAG12, LSC, OLD, etc). Meanwhile, genomic analysis has also indicated that there are many unknown genes that are involved in leaf senescence and other types of cell death (Zhu and Wang, 2000). An important model for leaf senescence at the molecular level is Arabidopsis thaliana (Buchanan-Wollaston et al., 2003; Lim and Kim, 2005). Arabidopsis is classified as a monocarpic plant, which has a short life cycle. Boyes et al. (2001) have defined the growth stages of Arabidopsis, which allows an accurate sampling of material for comparative analysis. The leaves of Arabidopsis plants undergo obvious developmental stages. It shows a well-defined and reproducible senescence program that makes genetic analysis of leaf senescence reasonable (Boyes et al., 2001). A wide-range of genomic resources available for Arabidopsis plants allows efficient identification and functional analysis of senescence regulatory genes.

Previously, Xiong (2007) identified and described a bioinformatics analysis of a novel gene family, Will Die Slowly (WDS). Five WDS family members were found in Arabidopsis thaliana (WDS1-WDS5). The predicted proteins of the WDS genes 
contain seven WD40 repeat motifs, which are conserved across many different species, such as Oryza sativa, Homo sapiens, Mus musculus, Rattus norvegicus, Bos Taurus, Canis familiaris, and Gallus gallus. These genes show sequence similarity $(54 \%)$ and identities $(35 \%)$ to the WDS of Drosophila melanogaster (Hollmann et al, 2002). The amino acid sequence of Drosophila melanogaster WDS shows that the gene codes for a protein with seven WD40 repeats and it belongs to the WD40-repeat family. The Drosophila melanogaster homolog has been implicated in cell death (Hollmann et al, 2002) and it provided a rationale for testing the roles of Arabidopsis WDS proteins.

By using quantitative PCR, Arabidopsis WDS1 was found to be expressed in all developmental stages (young and old rosette leaves and flower). Xiong (2007) found that wds1 knockout mutant showed a normal developmental phenotype. However, it exhibited an earlier onset of SAG12 expression than wild-type upon FB1 treatment. Thus, this observation indicates that WDS1 may have an important role in PCD. Moreover, Xiong (2007) found that the expression of WDS1 in detached wildtype leaves is up-regulated by salicylic acid (SA). Furthermore, overexpression of WDS1 resulted in an enhanced tolerance to hyperosmotic stress, which suggests an involvement of WDS1 in plant responses to stresses (Xiong, 2007). Senescence associated genes that show induction of gene expression in response to developmental factors are likely to encode proteins that have a role to play in controlling or manifesting the developmental changes (Guo and Gan, 2006; Miao et al., 2004; van der Graaff et al., 2006). Therefore, identification of senescence gene regulators that are up-regulated or down-regulated during senescence is a starting 
point for functional analysis followed by characterization of knockout mutations to identify the phenotypes in each gene during the senescence and cell death process. Studies taking molecular, genetic, and genomics strategies facilitate the understanding of the molecular mechanisms that are involved in controlling leaf senescence.

In this project, we characterized the Arabidopsis WDS2 gene and assessed its functions in senescence and cell death. The in vivo characterization of the WDS2 gene was first analyzed using the genomic tools available in the Arabidopsis information resource (http://www.arabidopsis.org), which has a large collection of TDNA insertion lines. I also studied the molecular phenotypes of $w d s 1, w d s 2$ and wds1 wds2 mutants. It should be noted that leaf senescence occurs at the final stage of leaf development. Consequently, WDS family genes that function in leaf senescence might also be involved in other biological pathways. Thus, one of the most important challenges in this study was to investigate how WDS2 is coordinately regulated during this process. For example, is WDS2 involved in the FB1, SA and/or MAPK pathways? If it is involved in one of these pathways is WDS2 involved upstream or downstream of these pathways? Our aim is to understand the molecular nature of the Will Die Slowly2 (WDS2) gene and the mechanisms that control leaf senescence. The goal of this research was to understand the genetic role of the WDS2 gene product by characterizing the function of WDS2 in leaf senescence, salicylic acid signaling pathway and Fumonisin B1-induced cell death (used as a pathogen elicitor). 


\subsection{Structure of WDS2}

We have characterized the Arabidopsis WDS2 gene (At5g08560), whose 2.2 $\mathrm{kb}$ cDNA encodes a novel of 589-amino-acid protein containing seven WD40 repeats and has two other domains on the $\mathrm{N}$ terminus, LisH and CTLH (Figure 1.1) (Table 3.1). The Arabidopsis WDS1-5 protein has been found to be similar to the WDS protein of Drosophila melanogaster (Hollmann et al., 2002). Originally, the WD40 repeats were found in the ß-subunit of heterotrimeric G-protein transducin, $G \beta$, and it is generally found in regulatory proteins, such as those involved in cell division, cell-fate determination, gene transcription, mRNA modification, transmembrane signaling, protein-protein interactions and vesicle fusion (Adler et al., 1999; Neer et al., 1994). Different studies show that crystal structures of two WD40-repeat proteins have a circularized seven-bladed beta-propeller structure, and each propelier blade consists of a four-stranded anti-parallel beta sheet (Voegtli et al., 2003; Wall et al., 1995). WDS2 protein likely has such a ß-propeller structure, but its interacting proteins and interaction mechanism have not been investigated yet.

In order to understand how WDS2 is functionally organized, it is necessary to know where the regulatory protein is located in specific plant cells and under particular environmental conditions. Thus, a GFP in frame fusion with WDS2 was used determine its subcellular location. The GFP-WDS2 fusion appeared to be in the nuclei of cells in tobacco leaves after transient delivery of a T-DNA harbouring the fusion and driven by the $35 \mathrm{~S}$ promoter (Figure 3.11). 4',6'-diamidino-2-phenylindole (DAPI) blue staining was used to label nuclei and in this cell co-labelled with GFP 
fluorescence (Figure 3.11-d). The result found in section 3.8 is not definitive and I cannot draw a final conclusion that WDS2 is located only in the nucleus. However, given that WDS2 might be nuclear localized, it may play regulatory roles in diverse cellular processes such as signal transduction, chromatin remodeling, chromosome condensation, cell cycle regulation, transcriptional induction/repression, vesicle trafficking, regulation of microtubule dynamics, and RNA processing (Neer et al., 1994; Smith et al., 1999; van Nocker and Ludwig, 2003; Vodemaier, 2001). The subcellular localization experiment of WDS2 should be repeated using stable transformants of Arabidopsis plant. Also, the fusion of GFP-WDS2 should be checked by Western blot using an anti-GFP antibody in order to make sure that the GFP-WDS2 fusion does not get cleaved.

\subsection{WDS2 functions in the regulation of leaf senescence and plant development}

The reproductive phase of plants depends on initiation of flowering time occurring under most favorable conditions. Plants have complicated mechanisms to sense biotic and abiotic factors, as well as their developmental and nutritional status, and to integrate this information to regulate their leaf senescence and many other internal processes. Arabidopsis plants initially grow in a vegetative phase producing rosette leaves, which are the repetitive production of leaves from lateral primordial initiated at the flanks of the apical meristem (Telfer et al., 1997). Moreover, juvenile and adult phases have been distinguished during rosette leaf growth on the basis of leaf morphology, trichome distribution, and acquisition of meristem competence to 
flower (Telfer et al., 1997). Thus, when all vegetative phases have completed their cycle and the floral phase is induced, leaf production is inhibited, lateral primordia develop into flowers, and the main stem elongates to give rise to an inflorescence (Boyes et al., 2001). Leaf senescence occurs in a coordinated manner at the whole leaf level, usually starting from the top margins toward the bottom of the leaves. Nevertheless, when environmental stress is involved locally on a leaf, the stressed leaf region undergoes earlier senescence than the other parts (Guo et al., 2004; Lim and Nam, 2005; Zhou et al., 2009).

Analysis of Arabidopsis mutants has allowed the identification of many genes involved in the regulation of leaf senescence. Physiological, genetic, and molecular analyses of leaf senescence mutants have shown that senescence is induced or delayed in several mutants, some of whose corresponding genes are dependent on hormones and/or environmental factors (Gracia-Heredia et al., 2008; Nam, 1997; Yoon et al., 2008). To investigate the role of WDS1 and WDS2 in leaf senescence, we tested loss-of-function mutants of $w d s 1$ and wds2. T-DNA mutant lines of wds1 (SALK_106374) and wds2 (SALK_100917) were obtained. Also, we performed double mutant analysis between $w d s 1$ and $w d s 2$ to determine the potential functional interactions or redundancy between WDS1 and WDS2 genes. In addition, T-DNA insertion, homozygous lines and absence of mRNA of these mutants were confirmed (Figure 3.1, 3.2, and 3.3). We found that the growth and development of wds1 mutant appeared normal, with no significant phenotype difference when compared to wild-type plant in leaf, flower or root development (Figure 3.4, Table 3.2). However, wds2 and double mutants exhibited a range of phenotypic 
abnormalities including early leaf senescence, early flowering, reduced rosette and cauline leaf numbers, and increased silique length (Figure 3.4, Table 3.2). The early leaf senescence phenotype of $w d s 2$ and $w d s 1$ wds2 mutants indicate that wds2 mutant is a new locus involved in the regulation of senescencing and plant development. The pleiotropic phenotype shown by wds2 mutant, which include early flowering time, reduce rosette and cauline leaf numbers and increased silique length, suggests the involvement of WDS2 in other developmental processes in addition to the regulation of senescence processes. Also, there are many genes that control these developmental processes (e.g. BOP1-1, WRKY7O, OLD, etc.) and these may work with WDS2 to control leaf senescence. Furthermore, the results shown in Figure 3.4 were consistent with the visible yellowing on the leaf of the mutants, suggesting an overall acceleration of leaf senescence in the wd2 and wds1 wds2 double mutants. The reason that we did not observe early leaf senescence in wds1 mutants is because the WDS2 gene is functioning normally. Thus WDS2 may have a more important role in the regulation of senescence. Also, the reason why leaf senescence showed earliest in the double mutants is because the two family members of WDS are knocked out. Therefore, there might be also functional redundancy within other WDS family members, but the WDS2 might have the most important role in regulation and controlling leaf senescence.

The senescence process also occurs in a highly regulated mechanism and the cell components are dismantled in an ordered progression. Chlorophyll degradation is the first visible symptom of senescence (Buchanan-Wollaston and Ainsworth, 1997; Lee et al., 2001). According to many studies, chlorophyll content is 
used as a relevant metabolic indicator of the early and late stages of senescence (Buchanan-Wollaston and Ainsworth, 1997; Hortensteiner and Feller, 2002; Lee et al., 2001; Lohman et al., 1994). The loss of green color is a quantifiable measure of leaf senescence (Thomas, 1997). To examine the physiological changes during senescence, the chlorophyll content was measured in the leaves of the $w d s 1, w d s 2$ and wds1 wds2 mutants compared to wild-type as shown in Figure 3.4-c. In the whole rosette leaf (Figure 3.4-a), measurement of chlorophyll fluorescence during leaf development showed a significantly higher loss of chlorophyll content in the wds2 $(26 \%)$ and wds1 wds2 mutants $(31 \%)$ compared to the wds1 mutant and wild type (6\%) (Figure 3.4-c). This observation supports the phenotypic analysis and the observed acceleration of leaf senescence in the wds2 and wds1 wds2 double mutants.

\subsection{WDS2 and osmotic stress}

As described earlier, leaf senescence is widely influenced by different factors and stress conditions. Thus, it is thought that genes regulating leaf senescence may also affect stress responses (e.g. hyperosmotic stress). Different studies of gene expression have shown that many of genes differentially expressed in senescing leaves are also influenced by various internal or external stresses, indicating that there is extensive signaling crosstalk between stress conditions and leaf senescence. To illustrate, along with the 43 transcription factor genes that are specifically induced during senescence, there are 28 transcription factors genes induced by various stresses in addition to senescence (Chen et al., 2005; Hanfrey et al., 1996; John et al., 1997; Quirino et al., 1999; Weaver et al., 1998). Hyperosmotic 
stress activates several protein kinases such as MAPK, which may mediate osmotic homeostasis and/or detoxification responses (Zhu, 2002). For example, some of the phospholipids-mediated signaling systems are triggered by osmotic stress, producing an array of secondary messenger molecules. Some of these molecules may have an important role upstream of the protein kinases activated by osmotic stress (Zhu, 2002). Figure 3.5 shows that phenotypic differences in wds2 and wds1 wds2 compared to wds1 and wild-type plant were influenced by osmotic stress conditions after $25 \mathrm{~d}$. Figure 3.5 provides experimental evidence that WDS2 is probably a molecular link that connects osmotic stress responses and leaf senescence. Also, as shown in Figure 3.6, there was no significant change in WDS1 transcript levels. However, I observed that treatment of plants with D-mannitol enhanced WDS2 transcription, suggesting that WDS2 gene expression is modulated by hyperosmotic stresses. This result suggests that WDS2 is not only a critical component in the regulation of leaf senescence, but also may play an important role in plant responses to hyperosmotic stress. Thus, our results are most consistent with the hypothesis that WDS2 is involved in the regulation of leaf senescence and cell death triggered by other environmental stresses.

\subsection{Up-regulation of WDS2 by salicylic acid.}

Senescence is known as a developmentally programmed process (Buchanan-Wollaston 1997; Smart, 1994). Nonetheless, it can be modulated by different plant hormones, such as ABA, ethylene and salicylic acid (Aharoni, 1989; Gan and Amasino, 1997; Nam, 1997). These hormones influence development and 
environmental responses in plants. The hormonal pathways tend to control all the stages of leaf senescence, progression, and the terminal phases. For leaf senescence, intimate interactions of senescence associated genes are involved and may have an important role in hormonal pathways that controlled senescence and PCD (Gan and Amasino, 1997; Nam, 1997). Each hormone is involved in a variety of developmental processes working in a complex manner, which causes difficulties in finding the specific functions of the hormonal pathways in leaf senescence (Gan and Amasino, 1997; Nam, 1997). Thus, hormones likely control genes during senescence in order to coordinate the senescence process with various physiological processes (Nam, 1997). Genes that show induced expression upon SA treatment may encode proteins that have a function in the senescence and PCD processes (Guo et al., 2004). As illustrated in Figure 3.7, the transcripts of WDS2 increased after 48 hours. The up-regulation of gene transcription of WDS2 following the treatment of $0.5 \mathrm{mM} \mathrm{SA}$ suggest that the WDS2 gene rapidly responded to signaling molecules triggered by biotic and abiotic stresses in the SA-dependent signaling networks. Most of the genes that are expressed during senescence require a combination of pathways for appropriate expression (Guo et al., 2004). Therefore, partial functional redundancy of cross-linking of signaling pathways between WDS2 and the other WDS family members may play an important role in SA-dependent signaling pathway. Also, creating triple loss-of-function wds mutants would give more insight into the role of WDS and allow the measurement of a significant difference in the process of leaf senescence as well as assist in revealing the specific roles of each member and functional redundancy within this family. 
Salicylic acid is the hormone involved in pathogen response and pathogenmediated cell death (Morris et al., 2000). Based on the gene expression patterns of WDS1 and WDS2 above and to determine whether WDS2 is involved in the senescence process induced by SA, we examined cell death in wild-type, wds1, $w d s 2$ and wds1 wds2 mutants after treatment with $0.5 \mathrm{mM}$ and $2.0 \mathrm{mM} \mathrm{SA}$. I found that the chlorophyll content of wild-type and wds1 leaves decreased rapidly to $18 \%$ and $23 \%$, with $0.5 \mathrm{mM}$ and $2.0 \mathrm{mM} \mathrm{SA}$ treatment respectively (Figure $3.8 \mathrm{a}-\mathrm{d}$ ), whereas the chlorophyll content in wds2 and wds1 wds2 leaves were less than $12 \%$ at the same times (Figure 3.8 a-d). This result indicated that the change in the chlorophyll content was significantly different between wild-type and wds2 and wds1 wds2, but not between wds1 and wild type. This result is consistent with the phenotypic analysis of these mutants in long day and short day conditions, which shows the acceleration of leaf senescence and degradation of chlorophyll content in both $w d s 2$ and $w d s 1$ wds2 mutants. Thus, these observations after SA treatment provide further evidence to support the hypothesis that WDS2 may function as a negative regulator in leaf senescence.

\subsection{Interaction of senescence and defense responses}

Genes that show increased expression in response to biotic or abiotic factors are likely to encode proteins that have a role to play in controlling or manifesting the developmental change (Gracia-Heredia et al., 2008; Lim and Nam, 2005; Yoon et al., 2008). As discussed earlier, identification of putative WDS genes that are upregulated during senescence was a starting point for functional analysis, using 
knockout mutations, to study the function of each gene in the senescence process. We found that the WDS2 gene is highly expressed during leaf senescence and is important for the plant to maintain viability during senescence process. Further investigation is needed to determine how the interaction between different senescence associated genes and signalling networks are linked together.

In addition, cell death associated with the hypersensitive response (HR) results in changes of cell structure and in the extracellular matrix, including callose deposition. Both senescence and HR are visible forms of programmed cell death even though they are not identical in their mechanisms and outcomes (Bostock and Stermer, 1989; Kim et al., 2008; Kus et al., 2002; Lim and Nam, 2005; Quirino et al., 1999). We observed that $w d s 2$ and $w d s 1$ wds2 exhibited accelerated HR compared to wild-type and wds1. Our data indicate a significant role of WDS2 in both senescence and defense signaling pathways. Therefore, activation of defense signaling pathways during the senescence process may provide a mechanism for resistance against pathogens. This mechanism might also protect susceptible organs against pathogen attack, which could impede the fundamental process of nutrient remobilization (Quirino et al., 1999, 2000). Consequently, WDS2 may be implicated in both developmentally regulating leaf senescence and defense signaling pathways. 


\section{Conclusion:}

In conclusion, in this thesis, I described the analysis of wds1 and $w d s 2$ knockout mutants. wds2 and wds1 wds2 mutants show accelerated leaf senescence, increased chlorophyll leaching and sensitive to osmotic stress, indicating that expression of WDS1 and WDS2 genes during senescence has a protective role to retain viability during this fundamental developmental process. Expression of WDS1 and WDS2 in wild-type plant is up-regulated by SA and WDS2 by hyperosmotic stress (D-mannitol). Also, by using the pathogen-derived cell death elicitor FB1, we found that the WDS2 is a novel gene for plant cell death signaling related to defense responses. The putative WDS2 protein contains seven WD40 repeats and might be located in the nucleus. Further studies on the loss-of-function wds mutants, isolation of WDS family members and elucidation of their roles in senescence and PCD will certainly help us understand the sophisticated regulatory mechanisms. 


\section{Future Direction}

Although much progress has been made in identifying and characterizing WDS1 and WDS2, significant work remains. First, quantitative real-time PCR should be applied to confirm the induction of WDS2 in SA and osmotic stress in order to follow up with the rest of the experiments. To further investigate the developmental role of WDS1 and WDS2, the transcript level of WDS1 and WDS2 should be also evaluated in response to age-induced senescence by collecting leaves at different developmental stages from Arabidopsis wild-type plants at 4-10 weeks and performing RT-PCR with gene specific primers. In this case, SAG12 gene would be used as a marker gene for the induction of leaf senescence as described by Kim et al., (2008).

In addition, phenotypic and expression level analysis on the rest of the WDS family will clarify the role of WDS family in plant development and leaf senescence. Looking at the expression pattern of all WDS family members might give insight into whether they function redundantly. To continue with our phenotypical analysis and investigation of the WDS family role, triple loss-of-function mutants should be obtained, as well as many possible losses of function members that can be obtained. This would allow for a more accurate phenotypical analysis that would distinguish the role of each WDS member in plant development and reveal whether a functional redundancy exist between those members.

At the mechanistic level, other challenges include the identification of leaf senescence and PCD initiation signals, and the recognition of developmental stages. Therefore, investigation of WDS2 function by identifying interacting partners of WDS 
members through yeast-two hybrid and the associated pathways will provide better understanding of the molecular mechanisms of longevity control in Arabidopsis and other systems. WDS1 and WDS2 were found to be induced by SA. WDS1 and WDS2 transcripts may also be enhanced by some additional factors present in senescing leaves. Thus, identifying the key signalling pathways involved in WDS gene regulation will give more insight into the role of WDS in leaf senescence and PCD. The work may also reveal more sophisticated coordination of all the WDS members in the fine regulation of plant development and in response to stresses.

Furthermore, site-directed mutagenesis of protein sequences is a powerful tool of modern recombinant DNA technology to determine the effects of amino acid substitutions on the functional characteristics of proteins. The ScanSite database reveal protein motifs that may be recognized by modular signaling domains, e.g. some motifs in a protein that are recognized and phosphorylated by Ser/Thr or TyrKinases (Obenauer et al., 2003). The amino acids S182, S363, 171, L166 and V525 of WDS2 are predicted to be sites of phosphorylation by MAPKs using Scansite. These should be mutated for further studies. The mutant WDS2 would be introduced into Arabidopsis to determine the function of WDS2 protein in the MAPK pathway. This type of analysis will reveal a critical component in the protein in determining the specificity, fidelity, and efficiency of mitogen activated protein kinase.

The PCD pathways remain unclear even in the model plant Arabidopsis. Based on our results and those in Asai et al. (2000), Morris et al. (2000) and Zhang and Klessig (2001), a model for WDS-mediated pathways is proposed (Figure 4.1). However, the function all WDS family members still has to be determined. 
Figure 4.1: A proposed model showing signalling pathways leading to WDS gene expression during PCD process.

Based on our results, bioinformatics analysis on MAPKs (data not shown) and proposed pathways in Asai et al. (2000), Morris et al. (2000) and Zhang and Klessig (2001), I hypothesized a model for WDS-mediated pathway. There might be two different pathways for WDS genes. The first pathway proposes the induction of WDS members in relation to each other on the MAPK cascade. Available evidence indicates that WDS genes are involved in the MAPK pathway based on the amino acids which are predicted to be sites of phosphorylation by MAPK using Scansite or published observations (Zhu et al., 2004). The other pathway in which WDS genes might be involved in is the salicylic acid pathway. Since both WDS1 and WDS2 are induced by $S A$, therefore they might be located upstream of $P R 1$, which is a marker for SA induction. After pathogen infection, pad4 mutant show decreases in PR-1 expression and salicylic acid accumulation (Asai et al., 2000; Jirage et al., 1999; Morris et al., 2000). PAD4 is found to be involved in leaf senescence and might play a role in the initiation of leaf senescence. WDS genes might and might not link both pathways to each other as well as activate other genes and signaling networks that might lead to PCD. 


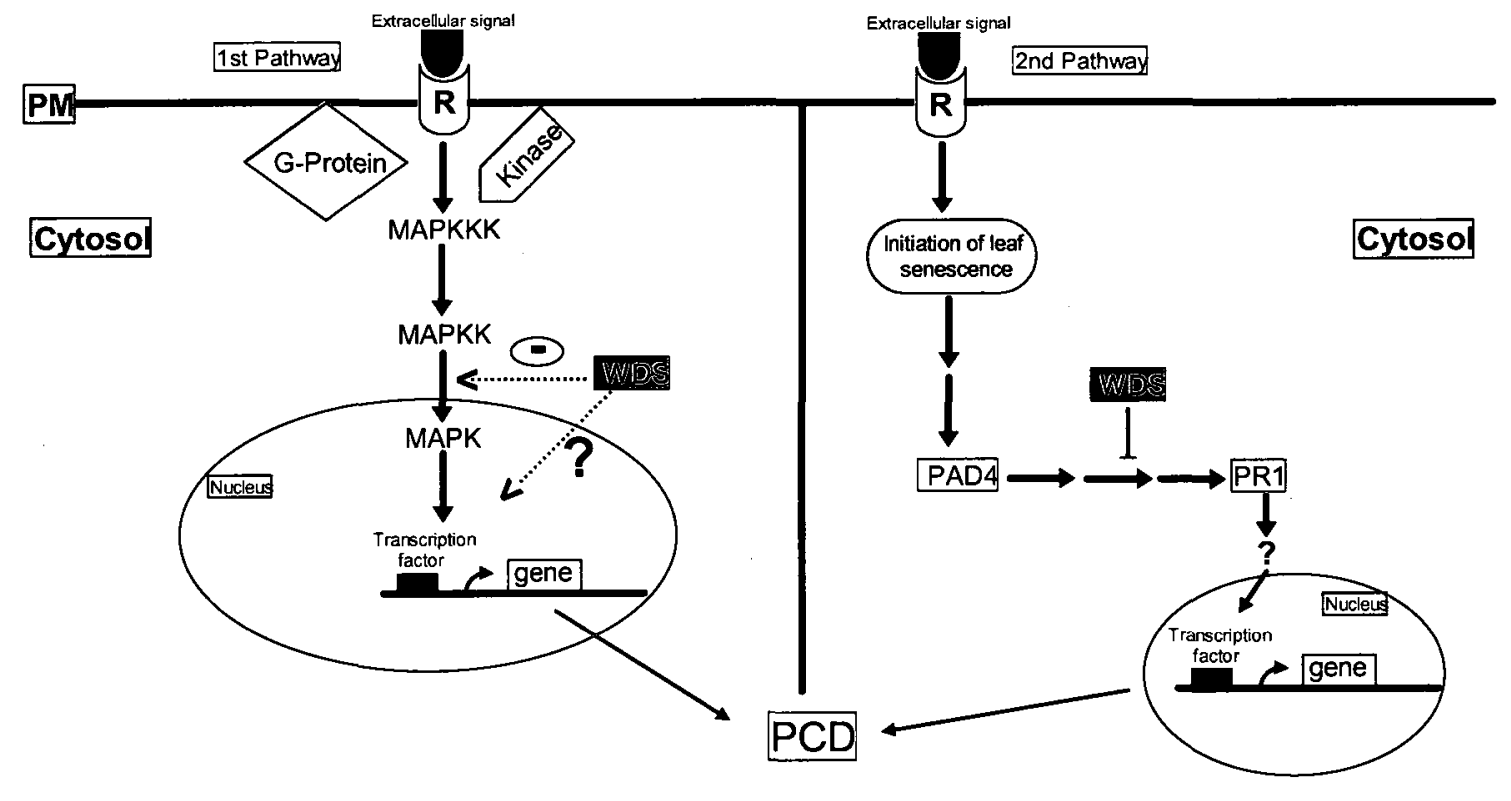




\section{APPENDIX}

Appendix A: Diagram of WDS2 Construct Map

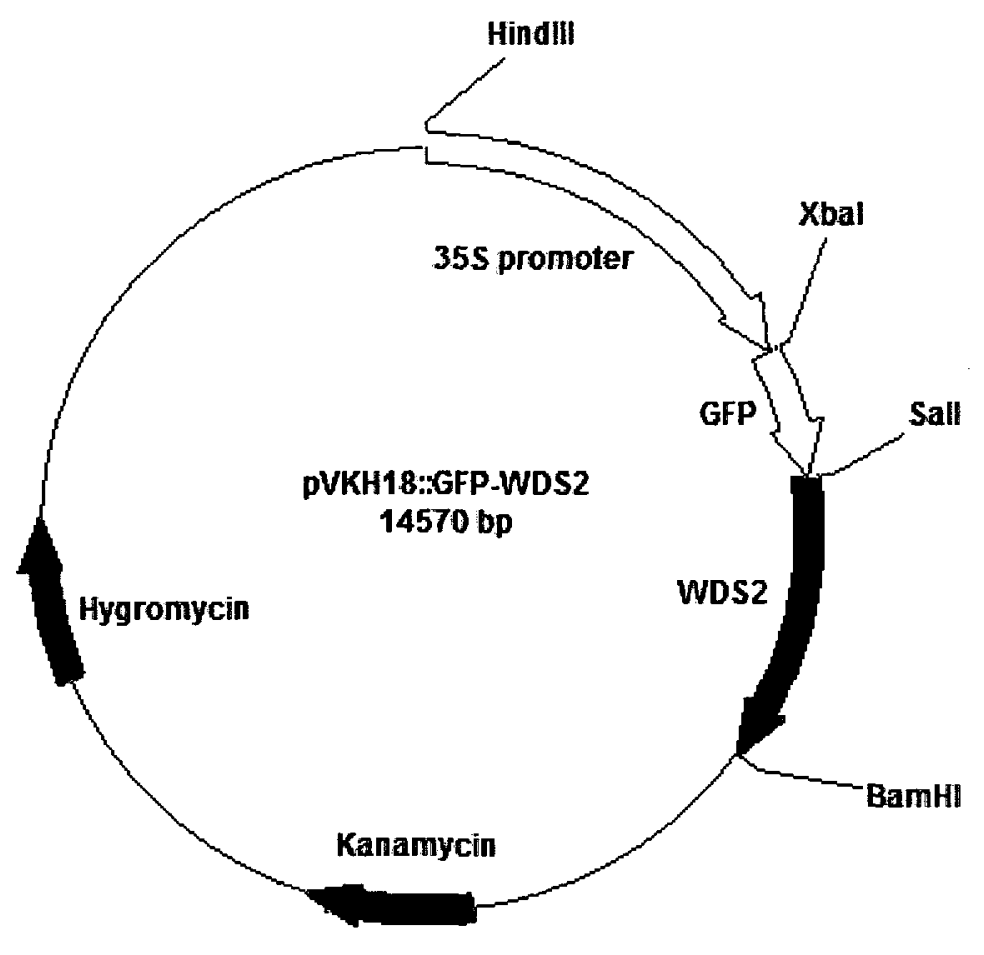


Appendix B: (a) Proposed salicylic acid biosynthetic pathways in plants (Mary et al., 2001). (b) Classical model for systemic acquired resistance (SAR) based on the presence of salicylic acid (Malamy et al.,1990; Metraux et al., 1990).

(a)

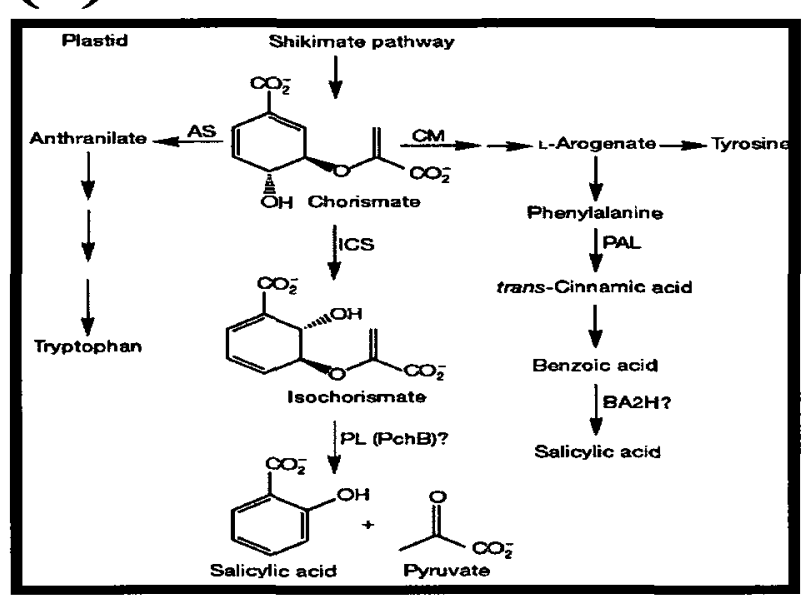

(b)

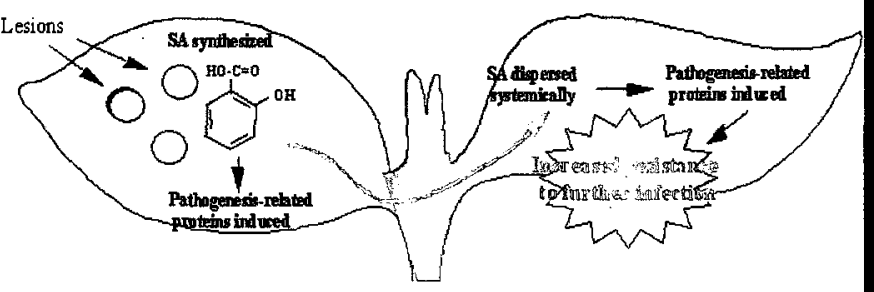




\section{REFERENCES}

Adler, H., Winnicki, R., Gong, T., and Lomaz, M. (1999) A gene upregulated in the acoustically damaged chick basilar papilla encodes a novel WD40 repeat protein. Genomics, 56: 59-69.

Aharoni, N. (1988) Interrelationship between ethylene and growth regulators in senescence of lettuce leaf disk. J. Plant Growth Regul., 8: 309-317.

Alonso, J., Stepanova, A., Leisse,T., Kim, C., Chen, H., Shinn, P., Stevenson, D., Zimmerman, J., Barajas, P., Cheuk, R., Gadrinab, C., Heller, C., Jeske, A., Koesema, E., Meyers, C., Parker, H., Prednis, L., Ansari, Y., Choy, N., Deen, H., Geralt, M., Hazari, N., Hom, E., Karnes, M., Mulholland, C., Ndubaku, R., Schmidt, I., Guzman, P., Aguilar-Henonin, L., Schmid, M., Weigel, D., Carter, D., Marchand, T., Risseeuw, E., Brogden, D., Zeko, A., Crosby, W., Berry, C., and Ecker, J., (2003) Genome-Wide Insertional Mutagenesis of Arabidopsis thaliana. Science, 301: 653-657.

Asai, T., Stone, J., Heard,J., Kovtun,Y, Yorgey, P., Sheen J., and Ausubel, F. (2000) Fumonisin B1-Induced Cell Death in Arabidopsis Protoplasts Requires Jasmonate-, Ethylene-, and Salicylate-Dependent Signaling Pathways. The Plant Cell, 12: 1823-135.

Bekir, U., Mukhtar, M., Somssich, I. (2007) The WRKY70 transcription factor of Arabidopsis influences both the plant senescence and defense signaling pathways. Planta, 226: 125-137. 
Bent, A. (1996) Function meets structure in the study of plant disease resistance genes. Plant Cell 8: 1757-1771.

Bleecker, A. and Patterson, S. (1997) Last exit: senescence, abscission, and meristem arrest in Arabidopsis. The Plant Cell, 9: 1169-79.

Boyes, D., Zayed, A., Ascenzi, R., McCaskill, A., Hoffman, N., Davis, K. and Gorlach, J. (2001) Growth stage-based phenotypic analysis of Arabidopsis: A model for high throughout functional genomic in plants. The Plant Cell, 13: 14991510.

Bostock, R., Stermer, B. (1998) Perspectives on wound healing in resistance to pathogens. Annual Review of Phytopathology, 27: 343-371.

Buchanan-Wollaston, V., Earl, S., Harrison, E., Mathas, E., Navabpour, S., Page, T., and Pink, D. (2003) The molecular analysis of leaf senescence: a genomics approach. Plant Biotechnol. J., 1:3-22.

Buchanan-Wollaston, V. (1997) The molecular biology of leaf senescence. J. Exp. Bot., 48: 181-199.

Buchanan-Wollaston, V., and Ainsworth, C. (1997) Leaf senescence in Brassica napus: cloning of senescence related genes by subtractive hybridization. Plant Mol. Biol., 33: 821-834.

Cao, J., Jiang, F., and Sodmergen, K. (2003) Time-course of programmed cell death during leaf senescence in Eucommia ulmoides. J. Plant Res., 162: 7-12

Champion, A., Picaud, A., and Henry, Y. (2004) Reassessing the MAP3K and MAP4K relationships. Trends Plant Sci., 9: 123-129. 
Chen, Z., Hong, X., Zhang, H., Wnag, Y., Li, X., Zhu, J., and Gong, Z. (2005) Disruption of the cellulose synthase gene, AtCes A8/IRX1, enhances drought and osmotic stress tolerance in Arabidopsis. Plant J., 43: 273-283.

Chivasa, S., Ndimba, B., Simon, W., Lindsey, K., and Slabas, A. (2005) Extracellular ATP functions as an endogenous external metabolite regulating plant cell viability. The Plant Cell: 17, 3019-3034.

Chothia, C., Hubbard, T., Brenner, S., Barns, H., and Murzin, A. (1997) Protein folds in the all-beta and all-alpha classes. Annu Rev Biophys Biomol Struct., 26: $597-627$.

Dan-Qiao, S., Liu, J., Xiang, Y., Ye, D., Sundaresan, V., and Yang, W. (2005) SLOW WALKER1, Essential for Gametogenesis in Arabidopsis, Encodes a WD40 Protein Involved in 18S Ribosomal RNA biogenesis. The Plant Cell, 17: 23402354.

Danon, A., Delorme, V., Mailhac N., and Gallois, P. (2000) Plant programmed cell death: a common way to die. Plant Physiol. Biochem., 38: 647-655.

Davis, R. (2000) Signal transduction by the JNK group of MAP kinases. Cell, 10: 239-252.

Doczi, R., Brader, G., Pettko-Szandtner, A., Rajh, I., Djamei, A., Pitzschke, A., Teige, M., and Hirt, H. (2007) The Arabidopsis mitogen-activated protein kinase kinase MKK3 is upstream of group $\mathrm{C}$ mitogen-activated protein kinases and participates in pathogen signaling. The Plant Cell, 19: 3266-3279. 
Dolferus, R., Jacobs, M., Peacock, W., and Dennis, E. (1994) Differential interactions of promoter elements in stress responses of the Arabidopsis Adh gene. Plant Physiol., 105: 1075-1087.

Eschrich, W., and Currier, H. (1964) Identification of callose by its diachrome and fluorochrome reactions. Stain Technol., 39: 303-307.

Fukuda, H. (1997). Tracheary Element Differentiation. Plant Cell, 9: 1147-1156.

Galaud, J., Laval, V., Carriere M., Barre, A., Canut, H., Rouge, P., and Lezica, R. (1997) Osmotic stress activated expression of an Arabidopsis plasma membraneassociated protein: sequence and predicted secondary structure. Biochimica et Biophysica Acta., 1341: 79-86.

Gan, S. and Amasino, R. (1997) Making sense of senescence. Plant Physiol., 113: 313-319.

Garcia-Heredia, J., Hervas, M., De la Rosa, M., and Navarro, J. (2008) Acetylsalicylic acid induces programmed cell death in Arabidopsis cell cultures. Planta, 228: 89-97.

Gilchrist, D. (1998) Programmed cell death in plant disease: The purpose and promise of cellular suicide. Annu. Rev. Phytopathol., 36: 393-414.

Guo, Y., and Gan, S. (2006) AtNAP, a NAC family transcription factor, has an important role in leaf senescence. Plant J., 46: 601-612.

Guo, Y., Cai, Z. and Gan, S. (2004) Transcriptome of Arabidopsis leaf senescence. Plant Cell Environ., 27: 521-49.

Hammond-kosack, K., and Jones, J. (1996) Resistance gene-dependent plant defense responses. The Plant Cell 8: 1773-1791. 
Hanfrey, C., Fife, M., and Buchanan-Wollaston, V. (1996) Leaf senescence in Brassica napus: expression of genes encoding pathogenesis-related proteins. Plant Mol. Biol., 30: 597-609.

Heazlewood, J., Verboom, R., Tonti-Filippini, J., Small, I., and Millar, H. (2007) SUBA: the Arabidopsis Subcellular Database. Nucleic Acid Research, 35: 213-218. Hirt, H. (1997) Multiple roles of MAP kinases in plant signal transduction. Trends Plant Sci., 2: 11-15.

Hollmann, M., Simmerl, E., Schafer, U., and Schafer, M. (2002) The essential Drosophila melanogaster gene wds (will die slowly) codes for a WD-repeat protein with seven repeats. Mol Genet Genomics, 268: 425-433.

Hopkins, M., Taylor, C., Liu, Z., Ma, F., McNamara, L., Wang, T., and Thompson, J. (2007) Regulation and execution of molecular disassembly and catabolism during senescence. New Phytol., 175: 201-214.

Hortensteiner, S., and Feller, U. (2002) Nitrogen metabolism and remobilization during senescence. J.Exp.Bot. 53: 927-937.

Jirage, D., Tootle, T., Reuber, T., Frost, L., Feys, B., Parker, J., Ausubel, F., and Glazebrook, J. (1999) Arabidopsis thaliana PAD4 encodes a lipase-like gene that is important for salicylic acid signaling. Proc. Natl. Acad. Sci., 96: 13583-13588.

John, I., Hackett, R., Cooper, W., Drake, R., Farrell, A., and Grierson, D. (1997) Cloning and characterization of tomato leaf senescence-related cDNAs. Plant Mol. Biol., 33: 641-651.

Jones, A. (2001) Programmed cell death in development and defense. Plant Physiol., 125: 94-97. 
Kerps, J., Wu, Y., Chang, H., Zhu, T., Wang, X., and Harper, J. (2002) Transcriptome changes for Arabidopsis in response to salt, osmotic and cold stress. Plant Physiology, 130: 2129-2141.

Kim, C., Bove, J., and Assmann, S. (2008) Overexpression of wound-responsive RNA-binding proteins induces leaf senescence and hypersensitive-like cell death. New Phytologist, 180: 57-70

Kinkema, M., Fan, W., and Dong, X. (2000) Nuclear localization of NPR1 is required for activation of PR gene expression. Plant Cell, 12: 2339-2350.

Kirankumar, S.M., Oswald, R.C., Robert, P.T., Otto, F. Peter, B.S. and Gregory, B. (2002) Comprehensive transcript profiling of Pto- and Prf-mediated host defense responses to infection by Pseudomonas syringae pv. tomato. The Plant J., 32: $299-315$.

Komachi, K., Redd, M., Johnson, A. (1994) The WD repeats of TUP1 interact with the homeodomain protein $\alpha-2$. Genes Dev., 8: 2857-2867.

Krishnamurthy, K., Krishnaraj, R., Chozhavendan, R., and Samuel Christopher, F. (2000) The programme of cell death in plants and animals - A comparison. Current Sci., 79: 1169-1181.

Kus, J., Zaton, K., Sarkar, R., and Cameron, R. (2002) Age-related resistance in Arabidopsis is a developmentally regulated defense response to Pseudomonas syringae. The Plant Cell, 14: 479-490.

Lam, E., Pontier, D., and del-Pozo, O. (1999) Die and let live-programmed cell death in plants. Curr. Opin. Plant Biol., 2: 502-507. 
Lamb, C., and Dixon R.(1997) The oxidative burst in plant disease resistance. Annu. Rev. Plant Physiol. Plant Mol. Biol., 48: 251-275.

Lamb, C. (1994) Plant disease resistance genes in signal perception and transduction. Cell, 76: 419-422.

Lara, B., Encarnocion, M., Garcia, G., Cruz, M., Fatima, Tahira, Rainer, Lee, Kyun, T., Proles, Reinhard, Tanner, Widmar, Roitsch, and Thomas. (2004) Extracellular invertase is an essential component of cytokinin-mediated delay of senescence. The Plant Cell, 16: 1276-87.

Lee, R., Wang, C., and Chan, S. (2001) Leaf senescence in rice plants: cloning and characterization of senescence up-regulated genes. Journal of Exp. Botany, 52: 1117-1121.

Letunic, I., Doerks, T., and Bork, P. (2008) SMAER 6: recent updates and new developments. Nucleic Acids Res., 1:1-4.

Levine, B., Jiang, H., Goldman, J., Griffin, D., and Hardwick, J. (1996) Bc1-2 protects mice against fatal alphavirus encephalitis. Proc. Natl. Acad. Sci., 93: $4810-4815$.

Li, J., Brader, G., and Palva, E. (2004) The WRKY70 transcription factor: a node of convergence for jasmonate-mediated and salicylate-mediated signals in plant defense. Plant Cell, 16: 319-331.

Lim, P., Woo, H., Nam, H. (2003) Molecular genetics of leaf senescence in Arabidopsis. Trends Plant Sci., 8: 272-78.

Lim, P., and Nam, H. (2005) The molecular and genetic control of leaf senescence and longevity in Arabidopsis. Curr. Top. Dev. Biol., 67: 49-83. 
Liu, Y., Zhang, S., and Klessig, D. (2000) Molecular cloning and characterization of a tobacco MAP kinase kinase that interacts with SIPK. Mol. Plant-Microbe Interact., 13: 118-124.

Loescher, W., Tyson, R., Everard, J., Redgwell, R., and Bieleski, R. (1992) Mannitol synthesis in higher plants. Plant Physiol., 98: 1396-1402.

Lohman, K., Gan, S. John, M., Amasino, R. (1994) Molecular analysis of natural leaf senescence in Arabidopsis thaliana. Physiologia Plantarum, 92: 322-328.

MAPK Group (2002) Mitogen-activated protein kinase cascades in plants: a new nomenclature. Trends Plant Sci., 7: 301-308.

Marion, J., Bach, L., Bellec, Y., Meyer, C., Gissot, L., and Faure, J. (2008) Systematic analysis of protein subcellular localization and interaction using highthroughput transient transformation of Arabidopsis seedlings. The Plant Journal, 56: 169-179.

Miao, Y., Laun, T., Zimmermann, P., and Zentgraf, U. (2004) Targets of the WRKY53 transcription factor and its role during leaf senescence in Arabidopsis. Plant Mol. Biol., 55: 853-867.

Morris, K., Mackerness S., Page, T., John, C., Murphy, A., Carr, J., and Buchanan-Wollaston V. (2000) Salicylic acid has a role in regulating gene expression during leaf senescence. Plant Journal, 5: 677-685.

Murray, A. (1998) MAP kinases in meiosis. Cell, 92: 157-159. 
Myoung, H., Lee, S., Kim, H., Jin, J., Kim, D., and Hwang, I. (2006) A WD40 Repeat Protein, Arabidopsis Sec13 Homolog1, May Play a Role in Vacuolar Trafficking by Controlling the Membrane Association of AtDRP2A. Mol. Cells, 22: 210-219.

Nam, G. (1997) Molecular genetic analysis of leaf senescence. Curr. Opin. Biotech., 8: $200-207$

Neer, E., Schmidt, C., Nambudripad, R., and Smith, T. (1994) The ancient regulatory protein family of WD-repeat proteins. Nature, 371: 297-300.

Nood'en, L. (1988) The phenomena of senescence and aging. In Senescence and Aging in Plants, ed. LD Nood'en, AC Leopold, pp. 1-50. San Diego: Academic.

Obenauer, J. Cantley, L., and Yaffe, M. (2003) Scansite 2.0: Proteome-wide prediction of cell signaling interactions using short sequence motifs. Nucleic Aceds Res., 31: 3635-41.

Pennel, R. and Lamb, C. (1997) Programmed cell death in plants. Plant Cell, 9: $1157-1168$.

Quirino, B., Normanly, J., and Amasino, R. (1999) Diverse range of gene activity during Arabidopsis thaliana leaf senescence includes pathogen-independent induction of defenserelated genes. Plant Mol. Biol., 40: 267-278.

Quirino, B.., Noh, Y., Himelblau, E., and Amasino, R. (2000) Molecular aspects of leaf senescence. Trends in Plant Science., 7: 278-282.

Ryals, J., Neuenschwander, U., Willits, M., Molina, A., Steiner, H., and Hunt, M. (1996) Systemic acquired resistance. Plant Cell, 8: 1809-1819. 
Shannon, M. Kaufman, T., Shen, M., and Judd, B. (1972) Lethality patterns and morphology of selected lethal and semi-lethal mutations in the zeste-white region of Drosophila melanogaster. Genetics, 72: 615-638.

Smart, C. (1994) Gene expression during leaf senescence. New Phytol., 126: 419448.

Smith, D., Niethammer, M., Ayal, R., Zhou, Y., Gambello, M., Wyanshaw-Boris, A., and Tsai, L. (2000) Regulation of cytoplasmic dynein behavioiur and microtubule organization by mammalian Lis1. Nat. Cell Biol., 2: 767-775.

Smith, T., Gaitatzes, C., Saxena, K., and Neer, E. (1999) The WD repeat: a common architecture for diverse functions. Trends Biochem Sci., 24: 181-185.

Stanghellini, M., and Aragati, M. (1996) Relation of periderm formation and callose deposition to anthracnose resistance in papaya fruit. Phytopathology, 56: 444-450.

Stone, J., Heard, J., Asai, T., and Ausubel, F. (2000) simulation of fungalmediated cell death by fumonisin B1 and selection of fumonisin B1-resistant (fbr) Arabidopsis mutants. Plant Cell, 12: 1811-1822.

Tang, X., Xie, M., Kim,.Y, Zhou, J., Klessig, D. and Marin, G. (1999) Overexpression of Pto Activates Defence Responses and Confers Broad Resistance. The Plant Cell, 11: 15-29.

Tena, G., Asai, T., Chiu, W. and Sheen, J. (2001) Plant mitogen-activated protein kinase signaling cascades. Curr. Opin. Plant Biol., 4: 392-400.

Thomas, H. (1997) Chlorophyll: a sumptom and a regulator of plastid development. New Phytologist, 136: 163-181. 
Tie, F., Furuyama, T., and Harte, P. (1998) The Drosophila polycomb group proteins $E S C$ and $E(Z)$ bind directly to each other and co-localize at multiple chromosomal sites. Development, 125: 3483-3496.

Tullio-Pelet, A., Salomon, R., Hadj-Rabia, S., Mugnier, C., de Laet, M., Chaouachi, B, Bakiri, F., Brottier, P., Cattolico, L., Penet, C., Begeot, M., Naville, D., Nicolino, M., Chaussain, J., Weissenbach, J., Munnich, A., and Lyonnet, S. (2000) Mutant WD-repeat protein in triple-A syndrome. Nat Genet, 26: $332-335$.

van der Graaff, E., Schwacke, R., Schneider, A., Desimone, M., Flugge, U., and Kunze, R. (2006) Transcription analysis of Arabidopsis membrane transporters and hormone pathways during developmental and induced leaf senescence. Plant Physiol., 141: 776-792.

van Doorn, W., and Woltering, E. (2004) Senescence and programmed cell death: substance or semantics? J. Exp. Bot., 55: 2147-2153.

van Doorn, W. (2005) Plant programmed cell death and the point of no return. Trends Plant Sci.,10: 478-483.

van Nocker, S., and Ludwig, P. (2003) The WD40-repeat protein superfamily in Arabidopsis: Conservation and divergence in structure and function. $B M C$ Genomics, 4: 50-61.

Voegtli, W., Mardrona, A., and Wilson, D. (2003) The structure of Aip1p, a WD repeat protein that regulates cofilinmediated actin depolymerization. J.Biol. Chem., 278: $34373-34379$. 
Wall, M., Coleman, D., Lee, E., Iniguez-Lluhi, J., Posner, B., Gilman, A., and Sprang, S. (1995) The structure of the G protein heterotrimer Gi 1b1c2. Cell, 83: 1047-1058.

Wang, D., Pajerowska-Mukhtar, K., Culler, A., and Dong, X. (2007) Salicylic acid inhibits pathogen growth in plants through repression of the auxin signaling pathway. Current Biology, 17: 1784-1790.

Ward, E., Uknes, S., Williams, S., Dincher, S., Wiederhold, D., Alexander, D., Ahl-Goy, P., Métraux, J., and Ryals, J. (1991) Coordinate gene activity in response to agents that induce systemic acquired resistance. Plant Cell, 3: 10851094.

Weaver, L., Gan, S., Quirino, B., and Amasino, R. (1998) A comparison of the expression patterns of several senescence associated genes in response to stress and hormone treatment. Plant Mol. Biol., 37: 455-469.

Kiedrowski, S., Kawalleck, P., Hahlbrock, K., Somssich, I., and Dangl, J. (1992) Rapid activation of a novel plant defense gene is strictly dependent on the Arabidopsis RPM1 disease resistance locus. EMBO j., 11: 4677-4684.

Williamson, J., Stoop, J., Massel, M., Conkling, M., and Pharr, D. (1995) Sequence analysis of a mannitol dehydrogenase cDNA from plants reveals a function for the pathogenesis related protein ELI3. Proc. Natl Acad. Sci., 92: 71487152.

Xie, Y., and Wu, R. (1989) Rice alcohol dehydrogenase genes: anaerobic induction, organ specific expression and characterization of cDNA clones. Plant Mol Biol., 13: $53-68$ 
Xiong, X. (2007) The role of Will Die Slowly1 (WDS1) gene in the development and defense response of Arabidopsis thaliana. M.Sc. Thesis. Carleton University, Ottawa, Ontario, Canada.

Xiong, Y., Contento, A., and Bassham, D. (2005) AtATG18a is required for the formation of autophagosomes during nutrient stress and senescence in Arabidopsis thaliana. Plant J., 42: 535-546.

Ynog-Qiang , G. and Gregory, B. (1998) Molecular mechanisms involved in bacterial speck disease resistance of tomato. Biological Science, 353:1455-1461.

Yoon, H., Kim, G., Kim, Y., and Park, C. (2008) Regulation of leaf senescence by NTL9-mediated osmotic stress signaling in Arabidopsis. Molecules and Cells, 25: 438-445.

Zhou, C., Cai, Z., Guo, Y., and Gan, S. (2009) An Arabidopsis Mitogen-Activated Protein Kinase Cascade, MKK9-MPK6, plays a Role in Leaf Senescence. Plant Physiology, 150: 167-177.

Zhu, T., and Wang, X. (2000) Large-scale profiling of the Arabidopsis transcriptome. Plant Physiol., 124: 1472-1476.

Zhu, J. (2002) Salt and drought stress signal transduction in plants. Annu. Rev. Plant Biol., 53: 247-273.

Zhu, Y., Wang, Y., Xia, C., Li, D., Li, Y., Zeng, W., Yuan, W., Liu, H., Zhu, C., Wu, X., and Liu, M. (2004) WDR26: A novel Gb-like protein suppresses MAPK signaling pathway. Journal of Cellular Biochemistry, 93: 579-587.

Zhang, S. and Klessig, D. (2001) MAPK cascades in plant defense signaling. Trends in Plant Science, 6: 520-527. 